\title{
12020
}

WANDERINGS IN THE

QUEENSLAND BUSH

W. LAVALLIN PUXLEY 
To Fresuglas Raix from tom a Custar $141 / 2 y$ 12020

alku 



\section{WANDERINGS IN THE QUEENSLAND . BUSH}






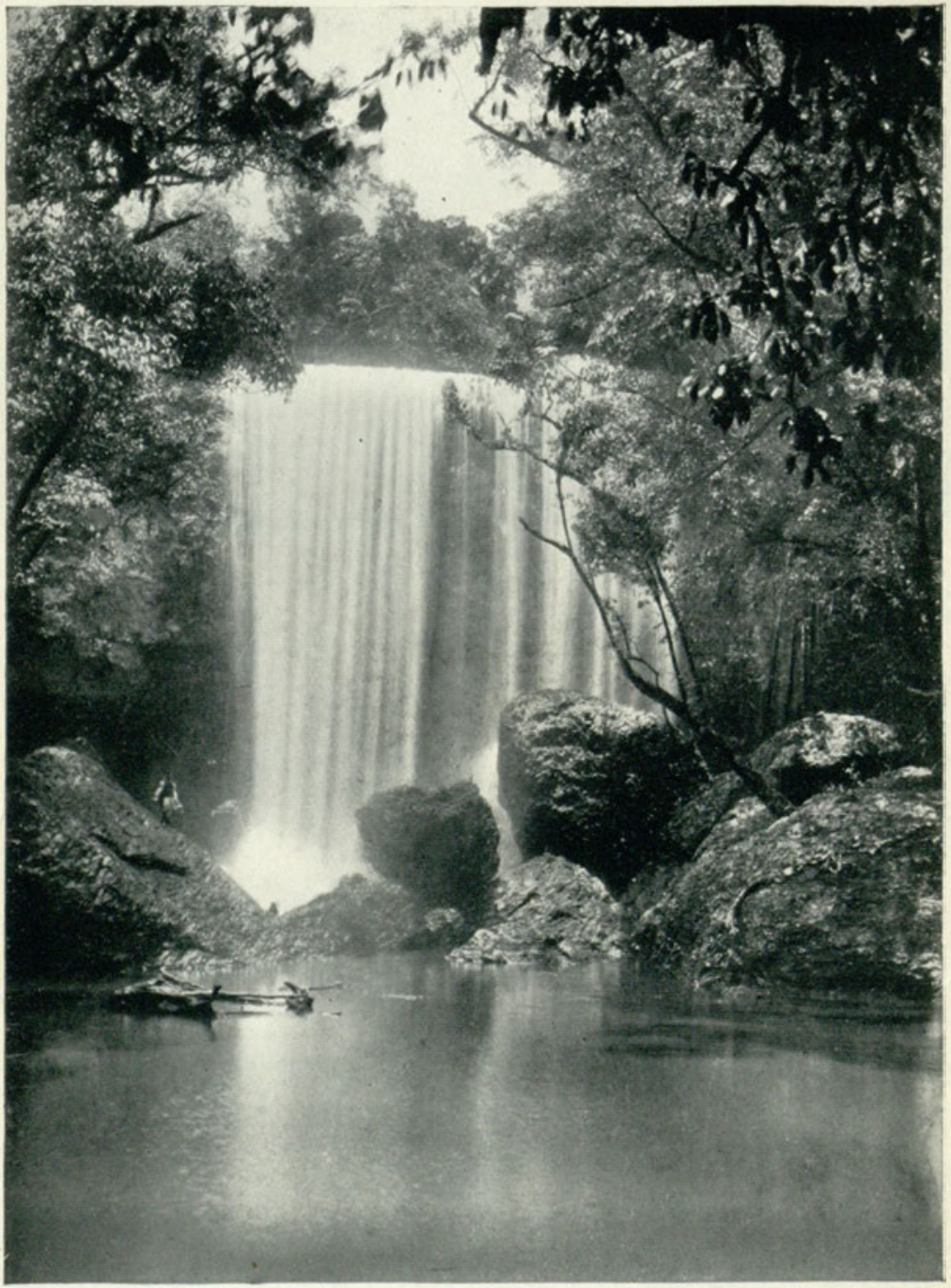

Board of Agriculture, Brisbane]

FISHER FALLS, INNISFAIL 


\title{
WANDERINGS IN THE QUEENSLAND BUSH
}

\author{
BY \\ W. LAVALLIN PUXLEY
}

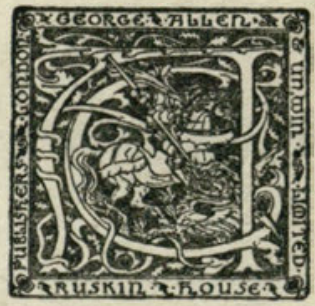

LONDON: GEORGE ALLEN \& UNWIN LTD. RUSKIN HOUSE 40 MUSEUM STREET W.C.I

CBGiOŚ, ul. Twarda 51/55

tel. 22 69-78-773

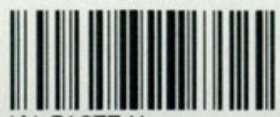


TO

F L O R E N E

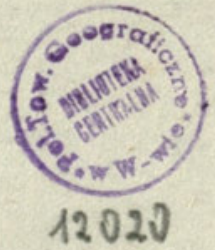

First published in 1923

[All rights reserved]

Printed in Great Britain. 


\section{FOREWORD}

IT seems difficult to single out any names from among such a number who showed me kindness while in Queensland, and who made my stay there one long round of pleasure; but I feel that I must take this opportunity of thanking a few of those who have helped me in any special way.

Amongst others I must mention Mr Wilson, of the Board of Agriculture at Brisbane, and $\mathrm{Mr}$ White, the Government botanist at the Botanical Gardens there; as well as $\mathrm{Mr}$ Nevitt, of the Legislature of Queensland; also $\mathrm{Mr}$ Greig, of Toowoomba, and Mr Philips, at Katoomba ; all of whom placed photographs or expert information, or both, at my disposal ; as well as numerous friends scattered throughout the State, and even chance acquaintances, all of whom helped to make my stay in Queensland a lasting memory of sunshine and pleasure.

W. L. Puxley. 


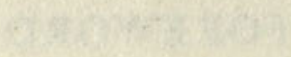
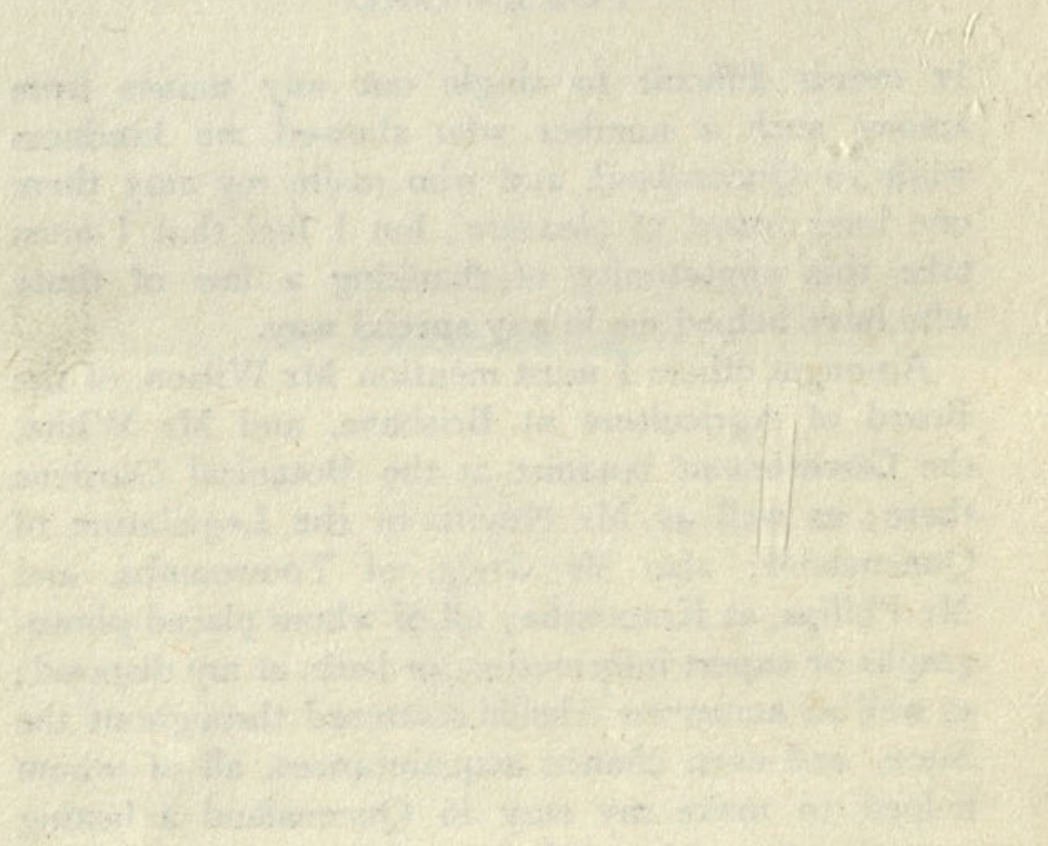


\section{CONTENTS}

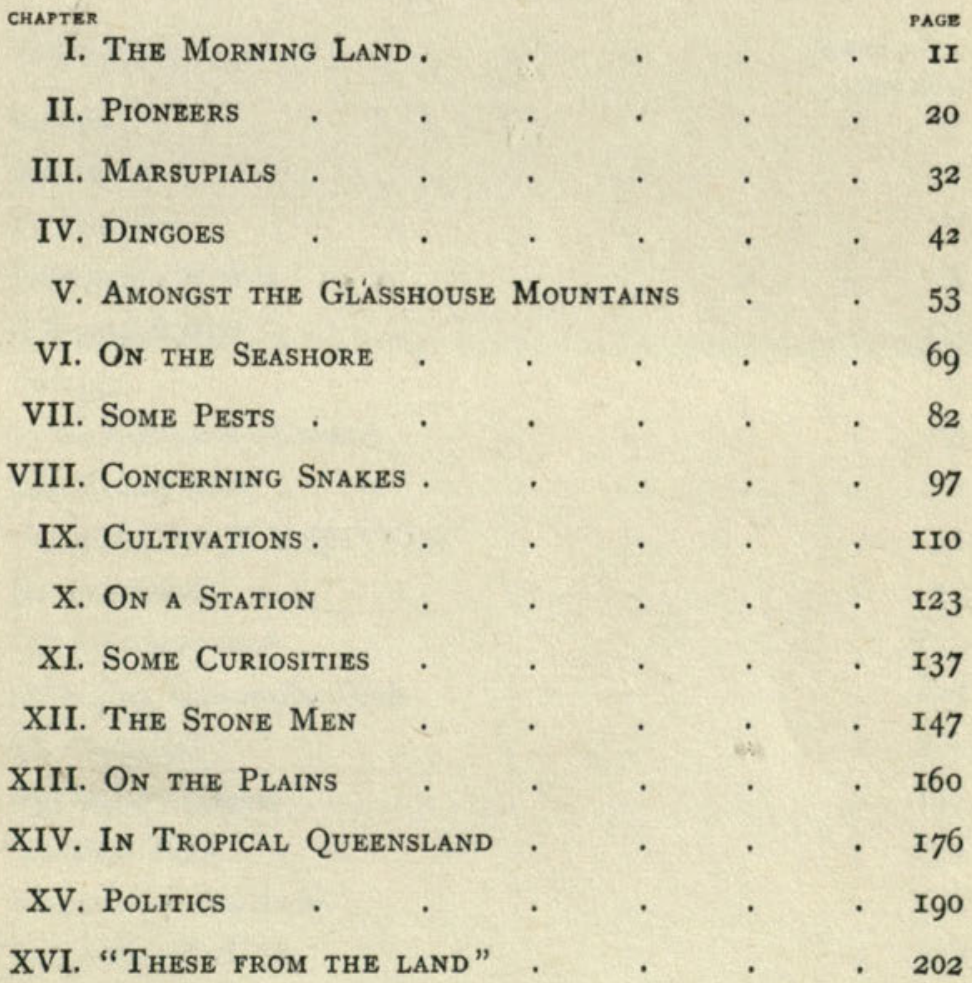





\section{ILLUSTRATIONS}

Fisher Falls, Innisfail

Frontispiece

FACING PAGE

Vanilla

Gum-trees

Pine-apples

Tasmanian Wolves ". . . . . . . 33

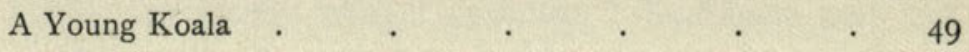

Drought . $\quad . \quad$. $\quad . \quad$. $\quad . \quad$. 49

In the Glasshouse Country a . . . 65

The Lonely Peak . $\quad$. $\quad$. 73

"Queen of the Colonies" Tree . . . . . . 73

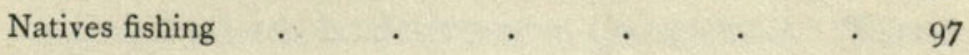

Cutting Sugar-cane $\quad$. . . . . . . II3

Collecting Milk in the Bush . . . . 129

Ox Transport . . . . . . . . . I29

Shoeing a Brumbie . . . . . 137

Sea-grass Balls . $\quad$. $\quad$. $\quad$. . . $\quad$ I37

Kookaburra and Snake . . . . . . 137

Australian Black . $\quad$. $\quad$. $\quad$. $\quad . \quad$ I53

Blacks hunting . . . . . . . I53

Grass-tree . . . . . . $I 6 I$

Bottle-tree . . . . . . I6I

Bananas . . . . . . . . . 177

Scrub Scenery $\quad$. $\quad$. $\quad . \quad$. 193

Tree-ferns

- 209 



\title{
WANDERINGS IN THE QUEENSLAND BUSH
}

\author{
CHAPTER I \\ THE MORNING LAND
}

I SHALL never forget my first morning in the bush. Early one lovely winter morning I had been put out of the train at a tiny wayside station bound for a "station" in the neighbourhood. The train itself and the line looked like a light railway to me, and I knew there was only one train per day to my destination. What I did not know then was the time telegrams take to be delivered in Queensland. Therefore having sent a wire from Brisbane two days before I did not know that I had outrun my wire until I found no one to meet me, and that I was more than twenty miles from the "station" where I was to stay. However, the day was lovely, and not too hot, and the whole surroundings looked so strange and fresh after the " man-stifled " towns where the past weary years had been spent, that it was impossible to feel anything but happy. So I wandered into the " café" which-with the store-had turned the little group of houses into a "township" and asked for breakfast.

When this was brought-and a very good one at that-the owner, in the kindly inquisitive way of the Queenslanders, asked me where I was going, etc., 


\section{I2 WANDERINGS IN QUEENSLAND BUSH}

and hoping for help from her I told her of my difficulty. A man sitting at a table near then joined in the conversation, and presently went out saying that he would see what could be done. True enough, he shortly returned, having found a friend who was going within six miles of my destination, and this gentleman most kindly offered me a lift, and accordingly we started off in a Ford car.

And now I am going to do a little advertising for Mr Ford, and this with no hope of reward, but only and solely from a sense of justice. For having now tried his cars again and again on what the Queenslanders humorously call their highroads, I consider that this gentleman deserves amply any fortune he may possess for inventing a machine which can survive such treatment as any vehicle must encounter which braves the terrors of the tracks in that beautiful land. Later on I got more used to the roads, but upon that first occasion I often felt that my last hour had come and that no one should venture across country in Queensland without a life insurance policy.

As we entered the bush within a mile of the township I saw we were making for a lake where the trees were thinnest, through which we splashed as fast as possible to prevent getting stuck, the bottom being rotten, as my host remarked, and a car having stuck there the day before. Getting through this in safety, though much shaken, we climbed the opposite bank and ran over what my driver called " sticks," but what I should have called limbs of trees, which were everywhere lying across the track. At last the road became so bad that we took to a space amongst the trees, where they grew less thickly 
than usual, and this I afterwards found was the common practice in Queensland to avoid the horrors of the roads.

As I was by this time feeling sea-sick from the jolting I had received, I ventured to ask my driver where we would get to the main road. He asked me shortly what I supposed I was on, to which I replied that I thought we were on a track through a wood. He answered still more shortly that I was on the highroad across Queensland; after which I thought silence was the best course to pursue for a while.

But how beautiful it was when the road was flat enough to see over it in any direction. Everywhere grew varieties of gums, and here and there we passed dense growths called "scrub" by the residents, and golden wattles in endless varieties were scenting the air. "Strange bright birds" were flying overhead with calls and song unknown to me, and I could hear in the distance the most beautiful sounds of the Queensland bush - the morning carol of the " magpies."

And here I must mention the strange way in which birds and trees are misnamed throughout Australia. The "magpie" of Australia is really a butcher-bird. The "robin" is a finch, the "box-tree" is a eucalyptus, the cedar is a tree with a bright green leaf (C. Joona), and in fact, though the names are taken from the old country, they are in almost every case misapplied. Even the beautiful mimosas, of which there are over a hundred varieties in Australia, have been christened wattles by the early settlers, who found in the pliant branches some resemblance to the wattle boughs of the land they had left behind.

Here and there I saw a box, large or small, fastened 


\section{I4 WANDERINGS IN QUEENSLAND BUSH}

to a tree where no house was in sight, intended for letters or goods to be left by the "Royal Mail" on its journey twice a week through the bush for the settler to whom the box belonged, and I afterwards saw this gentleman on several occasions with his wares spread out before him in the bush sorting those belonging to their various owners before continuing his journey.

After taking a good many more risks I eventually reached my destination and met the warm welcome one learns to expect in Queensland, and I will take this occasion to mention that during the whole of my stay in their beautiful country the same warmhearted hospitality met me everywhere. I think it is this, combined with the immensity of the great empty spaces, which draws one so much to the bush in Queensland. Certainly no part of Australia which I visited possessed such a charm for me as Queensland, all the more, perhaps, because she is looked upon as the Cinderella amongst the states and is pretty well left to herself. But Cinderella must remember the fate of her namesake in the old story, and unless I am very much mistaken the same fate will one day come to Queensland-that of rising to the top I mean-because it is impossible that so rich a country can remain secluded for ever. But I am glad that I have seen the "bonzer bush" before it was " discovered" and "developed" and while it was left such as "Creation's dawn beheld " it.

That first afternoon I walked out alone into the bush which surrounded the "station." I did not dare venture far, knowing well how easy it is to get bushed in a strange country. But I cannot imagine a happier feeling for a naturalist than to find himself 
in a new wild country, free to go where he wishes with a certainty of finding something new at every step. At anyrate I can think of nothing in this world for myself to compare with it in pure happiness.

That first afternoon I counted over twenty varieties of eucalyptus, many of which were coming into flower, and everywhere the pretty grey and yellow "soldier-birds" flew round me, scolding me and each other in their quarrelsome way. These are perhaps the very commonest birds in Australia, and I remember well how delighted I was later on in Africa to find the same bird establishing itself in Durban in the same way as so many foreign plants and birds and animals have done in Australia-often alas! to her great detriment. And even that first day I noticed the great number of laughing jackasses, or kookaburras as they are always called, and that they always seem to produce their wild laugh whenever anyone is in a difficulty, like some malignant imp rejoicing over one's troubles. I heard it that afternoon when I had sat down to rest upon an ant-heap which I had taken for a heap of soil which had been sifted. I was idly passing the tiny stones through my fingers when I noticed a number of the " beef ants," as they are called, rushing to repair the shingling of their roof which I had displaced, and rising hurriedly I heard overhead the loud laugh of two kookaburras, who had no doubt been watching me carefully. Close by, a turret of what looked like hardened red mud showed where the white ants had built, and indeed I soon saw numbers of both kinds of nests in every direction, as well as the homes of the tree ants, also built of mud and placed upon many of the trunks of the trees. 


\section{I6 WANDERINGS IN QUEENSLAND BUSH}

In the deeper shade lovely little blue wrens flew about, with their long tails twisting about-often right over their heads - and red and black ones also. And the willie wagtails, which are really flycatchers, were flying about wagging their tails sideways, not up and down as their English namesakes do.

Suddenly I heard a strange sound like the cracking of a whip. I did not then know of the stock-bird, and supposed that it was some human being, but could not understand what he was doing in that solitary place ; but later on I heard several more, and found the noise to proceed from a pretty little bird coloured something like our tits. It is said that it is only the males which make the crack, but at any rate it is strange how loud a sound can proceed from such a small throat. Once, later on, in a deep ravine in the mountains, I heard the same sounds again, made by several birds cracking against each other, and that time the noise was most striking in volume. It is one of the most distinctive bird-notes I have heard in any part of the world.

I love to dwell on that first afternoon in the bush when everything was so new and strange. Every "weed" that grew was of interest to me. The pretty purple sarsaparilla vine climbed everywhere, and in open spaces grew the everlastings we find in our gardens at home. Huge patches were covered with ageratum, which-first imported as a garden flower-is now classed as a " noxious weed," having become a pest in the land, where it is too much at home, and has taken liberties, as some guests have a trick of doing when they find themselves too comfortable. Orchids, too, grew on many of the trees, and these I found to be of three varieties, though 



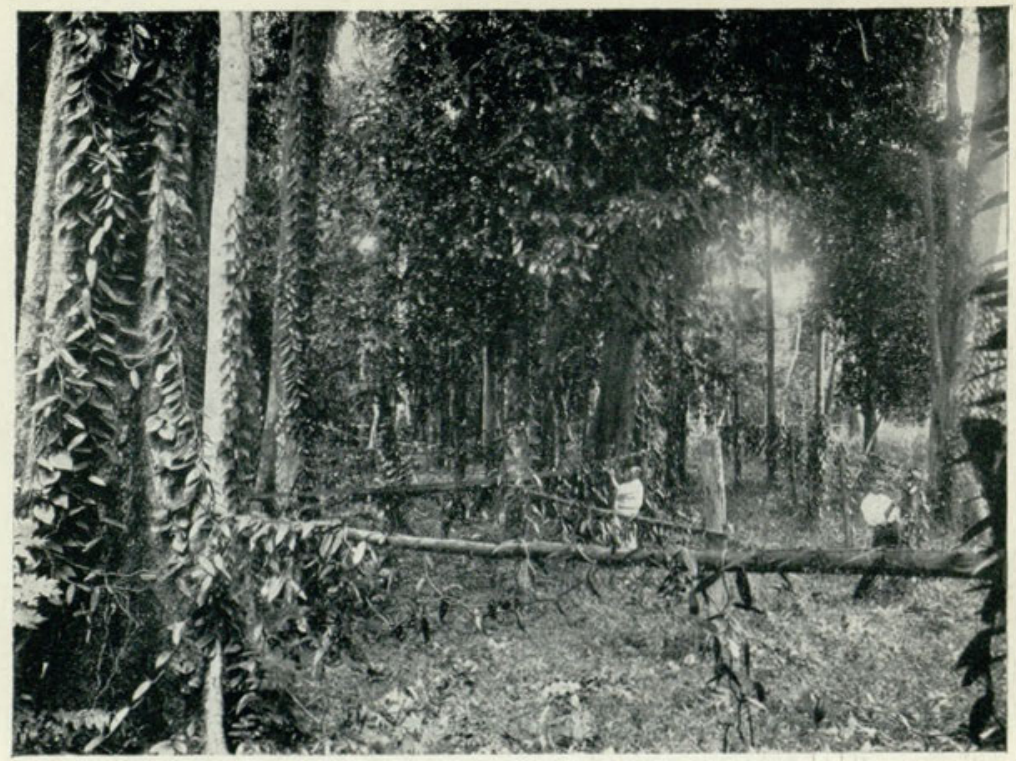

Board of Agriculture, Brisbane]

VANILLA

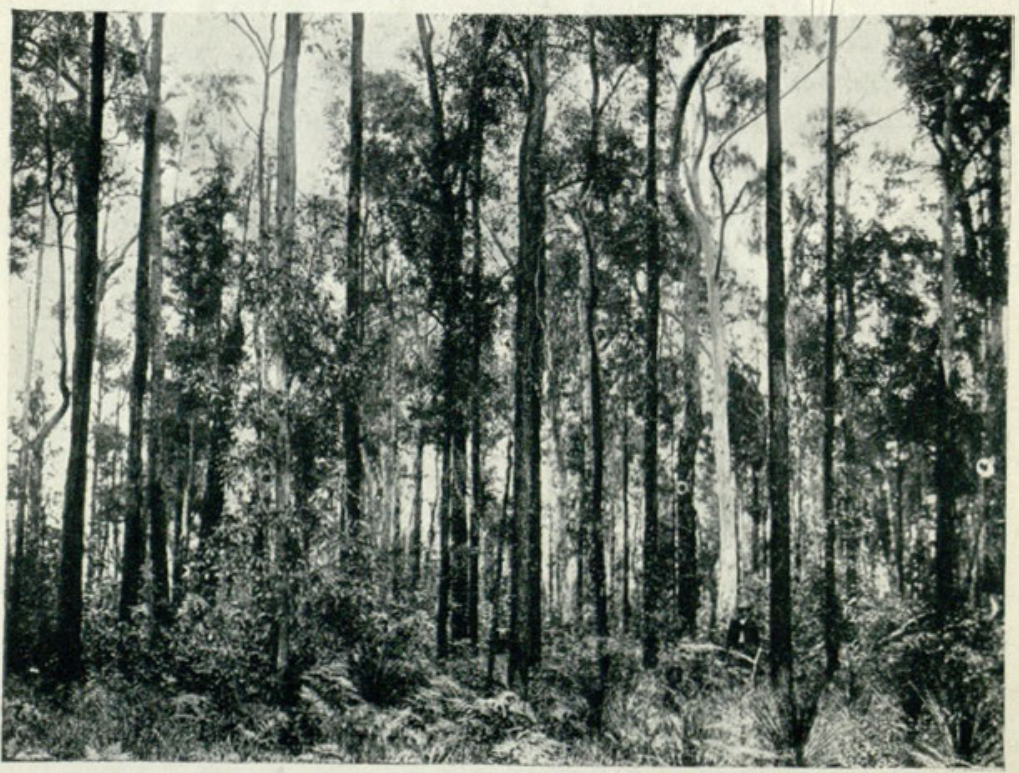


they were not yet in flower; but later on I found the yellow one in great profusion nearer the coast.

At last I realised that it was time to turn homewards, for the sun was setting behind the gums, and for the first time I noticed the strange unearthly effect of the Australian sunset. For from behind the white stems of the blue gums the sunset has a beautiful silver effect until the level of the branches of the trees is reached, when it turns to pure gold. I noticed this many a time afterwards, but never grew tired of seeing it, for the mists and hazes in Australia impart the greatest beauty to the landscape, and the melancholy of the bush does not detract from this effect. Indeed, in no other part of the world have I seen quite the same sunset effects, for everything is seen through this gold and silver haze. Later on in the night many sounds are to be heard. The mopoke calls solemnly at regular intervals, the curlews shriek like lost souls, kangaroo-rats jump with a tiny whiz and phalangers leap from the branches with their harsh call. Bears, too, can be heard "snoring" as they slowly awake from their heavy slumber, and bandicoots run about everywhere. Innumerable night insects begin to stir as night falls, while the sounds of the crickets and beetles are everywhere filling the air. But before these begin to wake to life there is a short pause between the lights, and then the sun begins to sink; and the sense of utter loneliness in the silence of the bush is good to feel after the rush and bustle of the crowded countries of Europe.

And so I slowly made my way home, and not too soon either, for before I reached it the sun had set and there was nothing left but a cloud of opal tints 


\section{I8 WANDERINGS IN QUEENSLAND BUSH}

where he had gone. I slept heavily that first night, till roused at dawn by the heavenly music of the carol of the magpies in the valley below.

And this-to me the most beautiful sound in the Australian bush-was almost the last sound I heard there ; for upon my last morning in Australia I went out early to try to hear them once more. Their best singing-time was over, but I heard them once more, and I was reminded of some lines I had heard about the Voices in the Bush by an Australian who loved them too:

"Have you heard the magpies calling in the dew-time cool and clear

When the bush is stirring softly in the breeze ?

Have you heard the waters falling where the timid wild things peer

And the hills and vales are murmurous with trees?

Have you heard the curlews crying when the dusk is over all ?

Have you heard the mopoke calling 'neath the moon?

Have you heard the tender music of the mountain waterfall ?

Have you heard by night the ocean's endless croon?

Have you heard the bell-birds tinkling in the fragrant mountain glens-

(Ah! the beauty and the greenness of those dells!) Where the wild wood is a refuge for the wagtails and the wrens And the air is full of chiming silver bells?"

I think what always struck me about the " Morning Land " was the mixture of youth and age about it. That is-that as regards the white population it was in its infancy, for they always seemed to me to be in the pioneer stage still, while all around me nature seemed to be so ancient. Every animal and bird almost seemed of an archaic type and the trees and green things also in some cases. The grass-trees, for instance, which I was never tired of, struck me so much 


\section{THE MORNING LAND}

in this respect. I remember asking a scientific man once while in Queensland what was the age of these trees. He replied that he had no idea, but that more than ten years before, feeling interested in this very matter, he had marked ten of the trees to observe their rate of growth. He pointed out several of those he had marked, and not one of them had moved an inch since he marked them-they were still in the stage of being like tufts of grass on the ground. He said that in all the years he had passed in Queensland he had never seen one which he could observe to have grown at all, even those which looked most thriving; therefore he was puzzled to know how long it took to enable them to form those thick stems we saw all round us.

And the tameness of the wild things showed their unfamiliarity with man ; for the birds in Queensland come quite near one. I remember the first morning the magpie-lark which tried again and again to get into my room through the open window, and though he hesitated he came in at last, and this with no inducement on my part nor any food to tempt him inside, merely the inquisitiveness of a wild creature which has not had that quality frightened out of him by sad experience, for the settlers do not molest the wild birds unless they damage their crops. So the kookaburras show no fear of man as he goes about his business, nor do the beautiful honey-birds or warblers-indeed many of them follow one about in the bush for long distances. This enables the bird-loving stranger to feel at home at once in the bush with so many "feathered fowl " of many kinds to accompany him and allow him to watch them and their ways at leisure. 


\section{CHAPTER II}

\section{PIONEERS}

No one can read the story of the founding of a nation or the discovery of a new land without a thrill because of the great things done by the pioneers. We are too late now to hope to find any more undiscovered countries, but the same qualities can be found in the men to go out into the new lands and fight a hard-often a desperate-battle with nature until they have "made good"; and something of this is going on in Queensland to-day. But it is the earlier pioneers whose stories read so like a romance now.

The first attempts were made from the south, to cross the Blue Mountains ${ }^{1}$ and reach the west or north by passing what we now know as the Great Divide or the Main Ranges, and in Mr Kipling's Explorer we see something of the qualities required in the man to whom the "whisper came," and who obeyed it. Such names as Bass, Blaxland, Lawson and others are recalled by the places named after them, but very few know the hardships they all encountered. Again and again they started out to try to pass those desperate ravines, which even now very few would care to attempt except in the places marked out for them. Bass in particular, though he was not destined to reach the land beyond,

1 This account of the crossing of the Blue Mountains is taken from the official records issued last year. 
underwent tremendous hardships to try to get past the ranges. When his hands and feet wore out he had iron hooks fastened to both in order to climb up those fearful precipices we see to-day from the foot-bridges provided by a paternal Governmenttogether with places here and there where we can boil our billy upon hooks, also provided with logs by the same parental care.

But Bass was forced to turn back, and years passed before Caley took up the task and got as far as the spot named "Caley's Repulse" to-day, for he built a cairn of stones there, but had then to turn back, believing the mountains to be "impassable." But at last three men set out, and these were the "men that blazed the trail." Their names were Gregory Blaxland, William Lawson and W. C. Wentworth, and they determined to conquer the mountains or never to return. The story of how they accomplished it makes one thrill even to-day. Day after day they climbed up precipices in which they had to cut "traverses" to help them to ascend. They crossed rivers on ropes and all the time had to keep a lookout for hostile blacks who were all round them attempting to cut them off. Towering crags and deep ravines rising or falling for many hundreds of feet, hungry and often thirsty for the water they could see but could not reach, at last, as Kendall says:

"They fought with nature till they reached the throne Where morning glittered on the great Unknown."

A tree was marked with the initials of the men who had got as far as what is now known as Mount York, but they were then obliged to turn back ; but not before they saw vast green country stretching 


\section{WANDERINGS IN QUEENSLAND BUSH}

below them, though they themselves were never to reach it. But another explorer-Evans-taking their instructions, set out to try to cross the second series of heights, and after enduring many hardships he managed to set foot in the "Promised Land." He returned to tell the band of settlers, who were suffering from a severe drought, that there were beyond the mountains "vast plains sufficient to satisfy the demands of the colony for a century at least." In return for his great services an Order was issued by the Government stating that "in return for his services Evans was to receive a thousand acres of land in Tasmania, and the post of DeputySurveyor." A cairn of stones now marks the spot where the explorers reached their farthest limit.

A humble member of one of these expeditions seems to have died on the way, and his grave is marked by a most curious inscription.

It gives his name as Corporal Travis, and states that he died in 1837 . Then are added the lines :

"Billitted by death I quartered here remain

But when the trumpet sounds I'll rise and march again."

To which some wag has added some poor Latin :

"Si sapis quesce

Suscitatus damnaberis."

Which a further wag has translated:

"Lie still if you're wise

You'll be damned if you rise."

One wonders what must have been the feelings of those first explorers when they saw the amazing waterfalls we all know now tumbling many hundreds of feet in huge leaps, with the rainbows dancing in the clouds of spray, which the wind tosses in dense 
masses into the air. And what other feelings of hopelessness must have sometimes come over them as they noticed the tiny patches of sky so far away in the air above the ravines. Did the storms break over the ravines while they were down below, with a noise so great that one cannot make oneself heard ? At any rate, it is well to know that these men at least died in peace, knowing that they had accomplished what they set out to do.

But when the mountain chain had been conquered, and the vast plains shown to exist, came the turn of the men who followed, and these, being so much farther from their base, had far more perils to undergo, though their difficulties were for a time no greater.

One of the first of these was Stuart, who set out from Adelaide in the hopes of crossing the continent from south to north, and the sad part of his story is that, after being absent for more than two years, he returned-broken in health-to tell the tale of his wanderings and stating that he had actually reached the sea on the north before turning back. He stated also that he had marked a tree with his initials and had buried a box containing his papers at the foot of the tree marked with his name. Unhappily he was so broken that he only returned to die shortly afterwards, with the sad knowledge that his story was believed in by no one. He was alone when he returned and could not prove the truth of his story, and he died in I866 under the stigma of being a fraud.

But many years later, in 1883 , a party of explorers, who had determined to survey the northern coast. from the sea, landed in the middle of a mangrove swamp and made their way painfully through the 


\section{WANDERINGS IN QUEENSLAND BUSH}

deep, evil-smelling ooze. For miles they went, passing - as you can pass them to-day-flocks of spoonbills, cranes, and wild duck, until they reached higher land and found themselves in scrub country with all the denseness of the tropics. Through this they forced their painful way, at the rate of a few miles a day, until at length they emerged into open plain country and found themselves in the near neighbourhood of the place so minutely described by Stuart years before. All of a sudden they recognised the striking-looking tree he had also described, standing out by itself, and approaching they found, almost grown over by the bark, the initials of the man no one had believed in:

$$
\text { "J. M. D. S." }
$$

No more, but that was enough. No native could have understood the letters, but the white men knew what they meant. The box was gone, but they returned and made what amends they could to the memory of the man all had wronged.

Then came the most harrowing story of any in the history of Australian exploration. Three men, Wills, Burke and King, set out to seek what lay beyond the "Stony Desert" of Stuart-that mysterious region of gibbers and quartz-crystals in the heart of Australia. They started from Cooper's Creek, in the east, leaving a man named Brahé there, with instructions not to leave the camp till they returned, while another of their number went back to bring up further supplies in case these were needed later on, but he was to be under the orders of Brahé. To this man was due the tragedy which befell later. 


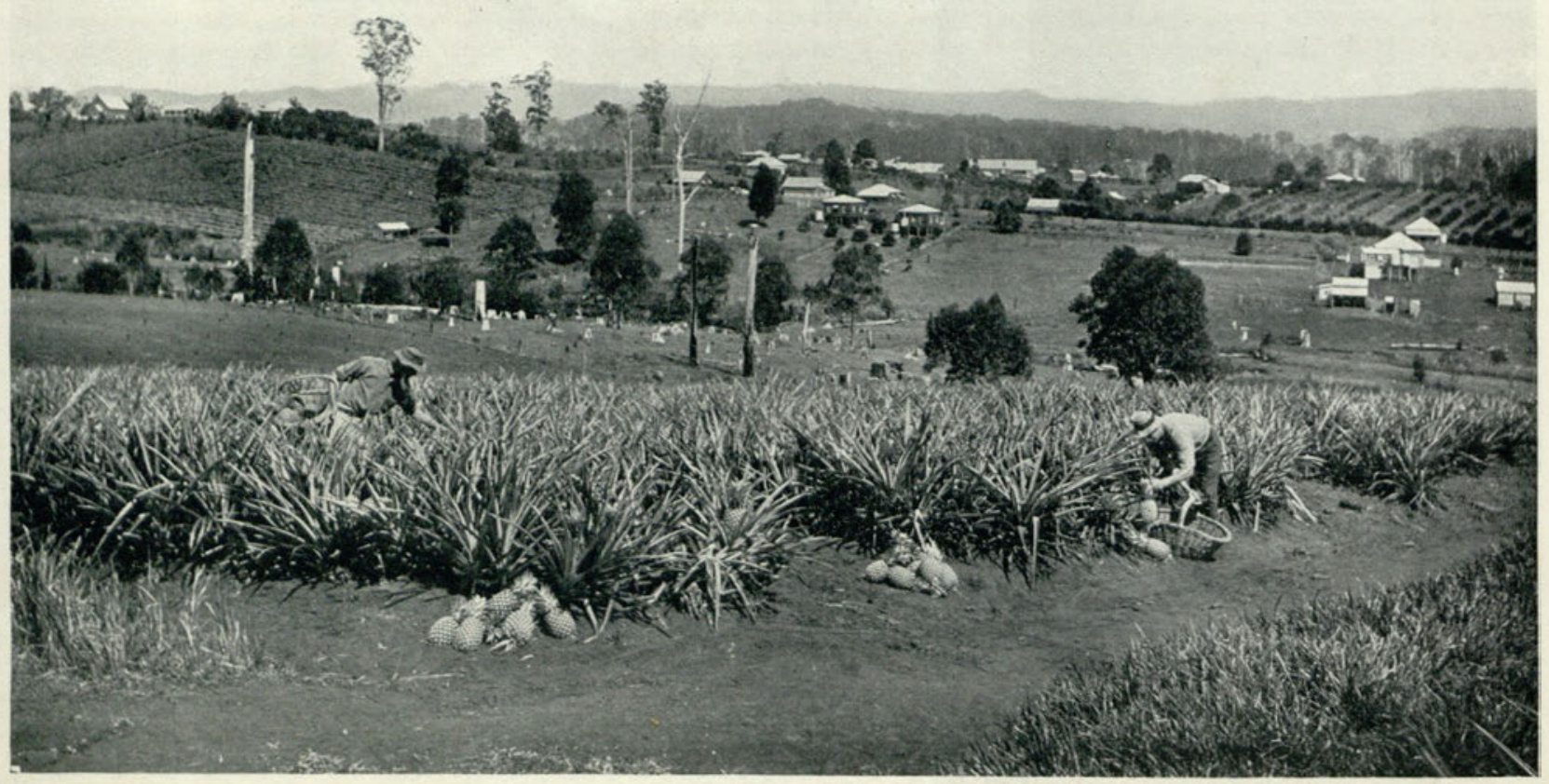


Wills and the others started off, but almost from the first misfortune dogged them. In one camp several of the camels strayed, and after spending a day searching for them they did not dare delay longer, and left without them, taking a prospector they met with them named Gray. This left them with too few animals to carry themselves and their loads, and some of these had to abandoned. Then came the desert, with its few springs and its burning thirst, and they were forced to turn and make their way slowly and painfully back to Cooper's Creek, with their stock of provisions gone and only two worn-out horses and a camel left. What was their horror to find a letter from Brahé to say that he had grown hopeless of their return and had started off for home, "with twelve good horses and the camels." They thought of following him, but could not, owing to the wretched state of their horses. They found, however, a little food he had left. This they ate, and after a day's rest they determined they must somehow make for home and the coast. Had they known it, Brahé was not far off, having taken a leisurely ride of a few miles and then camped.

The three men, with Gray as a guide, to save the distance determined to push straight across country, and after going some way they fell in with a party of blacks. These, in exchange for some of the tattered clothing of the explorers, gave them some of their own coarse food, which consisted of nardoo, a flour made from the seeds of the marsilea, a plant growing in the moist spots in the desert ; and they showed the wretched men how and where to get more of it. Upon this they chiefly lived, with what little provisions they had brought with them, until 


\section{WANDERINGS IN QUEENSLAND BUSH}

Gray complained of pains from eating nardoo and was caught robbing the stores one night, for which the others thrashed him; but he was weak and ill, and a few days later he died. The three others, who were on the verge of breaking down themselves, made their slow way back to Cooper's Creek, in the faint hope of finding that Brahé had returned. And this he had actually done upon finding Wright coming up with the extra stores, but not finding traces of the return of the others he left another note, and ordering Wright to return with him he left the place for good and went back to Sydney.

When the three men got back, Wills was so weak that it was resolved to leave him there with the stores and a rifle, while Burke and King went off by themselves for help if they could get to the coast. Wills' diary is most pathetic. Almost the last entry is a short statement that he was weak " in spite of nardoo and a crow" he had managed to shoot, and two days later he died.

The other two again fell in with a camp of blacks who befriended them, but the native food did not suit Burke, who also died soon afterwards. King was now left alone, and could not even attempt to get back across country by himself, so he remained with the blacks for three months, when a party of whites who had come to search for the ill-fated party got upon his track and found him, almost naked, and gaunt and nearly starved to death, though the blacks had throughout done their utmost for him. This sole survivor of the ill-fated expedition managed to get back alive, but utterly broken in health.

Though full of pluck and enthusiasm, these were not the best men to choose for exploration across 
bush country. Not one of them but Gray had the faintest knowledge of the country, and they would not have perished, according to the settlers there at the time, had they understood how to procure some of the game which then abounded in the district, and even now there is no lack of wild-fowl in many parts they traversed. But a curious relic of the expedition came to light some years later when a settler in a lonely district-the only white one for very many miles - saw a native running toward him " clothed in smiles," but with deadly fear on his face, and told him that something "top side emu, bottom side close up sheep. Terable big fella," was near at hand. Taking his rifle, the old settler went in search, suspecting that the native had seen one of his own bunyips; but what was his surprise at finding a camel! At first he wondered how to catch it, suspecting that it was wild by this time, wherever it had come from, but as he longed for a ride he determined to have a try, and upon going close he was pleased to find that the camel knelt down for him to mount, and within a very few minutes he was riding on the " sheep-emu," to the no small terror of the blacks near. He afterwards heard of the camels said to have been lost by Wills and Burke, and had little doubt that this animal was one of those which had strayed.

Most of the early explorers in Australia-as in so many other parts of the world-lost their lives in opening up new countries. Captain Cook was speared by the natives in reprisal for injuries done by others of his race, just as later on Bishop Patteson paid the penalty of his people's cruelty to the natives of the islands, who vowed they would take the life of 


\section{WANDERINGS IN QUEENSLAND BUSH}

the first white man they could catch, which proved to be the noble bishop who had spent his life for them. And La Perouse, after landing at the spot which still bears his name, sailed away to the north of Queensland and was never heard of again.

One of the most dramatic of the expeditions was that of Dr Leichhardt, whose name is borne by a beautiful pine. This explorer determined to explore the north of Queensland, and set out through the centre of that state for this purpose. But not only was he never heard of again, but not a trace of him or his party was ever discovered until a tree was found on which was carved the letter " $L$ " and beneath it the single word "Dig" - with an arrow pointing downwards. This tree stands at the junction of the Nogoa and Comet rivers, and was found by the Hon. C. Gregory, who recorded in his journal that he had found it "together with traces of a fire and bones of a goat," but no news could be gained of the explorer. This was in the year I856, nine years after Leichhardt had started. At the present time the word "Dig" is still visible, but the bark has overgrown the rest. No trace of the buried articles could be found, though a careful search was made for them.

One more tree, a Moreton bay ash, was found also, this time near Springsure on the Crystal Creek, also marked, but the marks have become so faint that it cannot be known by whom it was so marked, though it is supposed that this was done by Leichhardt, as this was the route he would probably have taken; but he himself was seen no more. Possibly he perished by the sudden rising of the rivers in the north, which may easily have swept him and his little 
camp away, or by the hands of the blacks, or he may have wandered into the desert and died of thirst, or hardships ; however that may be, it will never be known now.

In the case of Stuart's tree it was suggested at one time that it should be cut down and brought to Adelaide in memory of him, but it was thought better to leave it where and how he had marked it. Unhappily a bush fire swept over the place some years ago and the tree was utterly destroyed, so that nothing is left now to recall the journey which cost this brave man his life. But perhaps it was reward enough for him at the last to remember that -

"Anybody might have found it-but His Whisper came to me!"

For, after all, it is seldom the pioneers who reap the material benefit of their labours. An Australian poet has most truly written :

"When they pin the Stars and Garters, when they write the titles rare,

The men who earned the honours are the men who won't be there."

Probably it was of such men as these he was thinking when he wrote those lines.

And it is exactly the same qualities as those required by the pioneers of the past which are needed by the young men of to-day who are "digging themselves in " in the new countries. First the tent, then the humpy of bark, then the little brown house on its tall piles, and after that, with luck, success; if not-then the other thing. But in any case, it is as well to be prepared for anything. I remember seeing a motto on the walls of a settler's house in a new part of the country. This man had begun his 


\section{WANDERINGS IN QUEENSLAND BUSH}

life out there a few years ago in the bush on a hillside. It must have seemed a fairly hopeless thing at first to hack out a living from the dense scrub, but he had held on, in hot and cold, in drought and floods, until, when I saw the place, it was cleared, and the crops had begun to come in, and he was constantly breaking new ground. I was struck with the motto he had selected, though as poetry it may have lacked something :

\footnotetext{
"When all the world seems all dead wrong And business gone to bum ;

A four-inch grin and a lifted chin

Helps some, my boy, helps some."
}

Something of the same kind must have been the motto of the earlier pioneers, though it may have been more elegantly expressed.

And there is a singular charm about the free life in a new country. It may be one of hard work and danger and many difficulties, but it is never monotonous, as life so often is if lived in one of the brick boxes which cover so many weary miles in the old country. And even if wealth does not come to the pioneer or the settler in a new land he knows his feet are set in the right path. I remember once coming upon three lonely graves in the heart of a forest in Mozambique. They were marked only by small crosses of wood enclosed in a little square of posts and wire, and the names upon them were almost effaced. I could read only one word, "Charles..." -for only the names had been written-probably those of men engaged upon the railway which runs from Beira inland, of which it has been said that " every sleeper cost a white man's life." But these 
humble pioneers who opened up that country did their share just as a coral insect does his when he fastens his tiny body to the reef on the millions of his kind who built below him. And those who have lived that life, and engaged in the stern fight with nature which life in a new country involves, would not willingly leave their wide spaces for the more cramped existence of life in one of the little old countries, wherever those "great spaces" are situated, or whether they would be described as rolling prairie or high veldt or bonzer bush.

"Earth's mightiest isle; she stands alone.

The wide seas wash around her throne,

Crowned by the red Sun as his own.

She called men to her, and they came,

Whose deaths have given the desert name:

Their fame is written with her fame.

The trust is ours, to us alone,

We are the sure foundation-stone,

The seed from which the flower is grown." 


\section{CHAPTER III}

\section{MARSUPIALS}

WANDERING in the bush "way back" in Australia one seems to be transported to the bygone ages, to the days before that continent was separated from Asia, when the East India Islands were not yet islands at all, but part of a great peninsula stretching from China to Tasmania.

If scientists are right, the marsupials originated in about the latitude of Southern Europe, and followed the great southern trend until they gradually spread all over Asia and reached the limits of the continent of what is now known as Australia. Then came some convulsion of nature-possibly very suddenly - and cut Australia off from the continent to the north, leaving only the islands of New Guinea, Borneo, etc., to mark where land had once been. In this remote corner of the world they were saved from the fate of their fellows elsewhere, who gave place to mammals of more highly developed form, which superseded them and gradually proved their ruin in other continents.

While the placental mammals evolved and replaced the marsupials elsewhere, those lowlier forms - secure in their island continent-remained down to the present time; so that even now they represent practically all the native mammals in Australia-at any rate if we except the doubtful dingo, which has so little in common with any other indigenous 



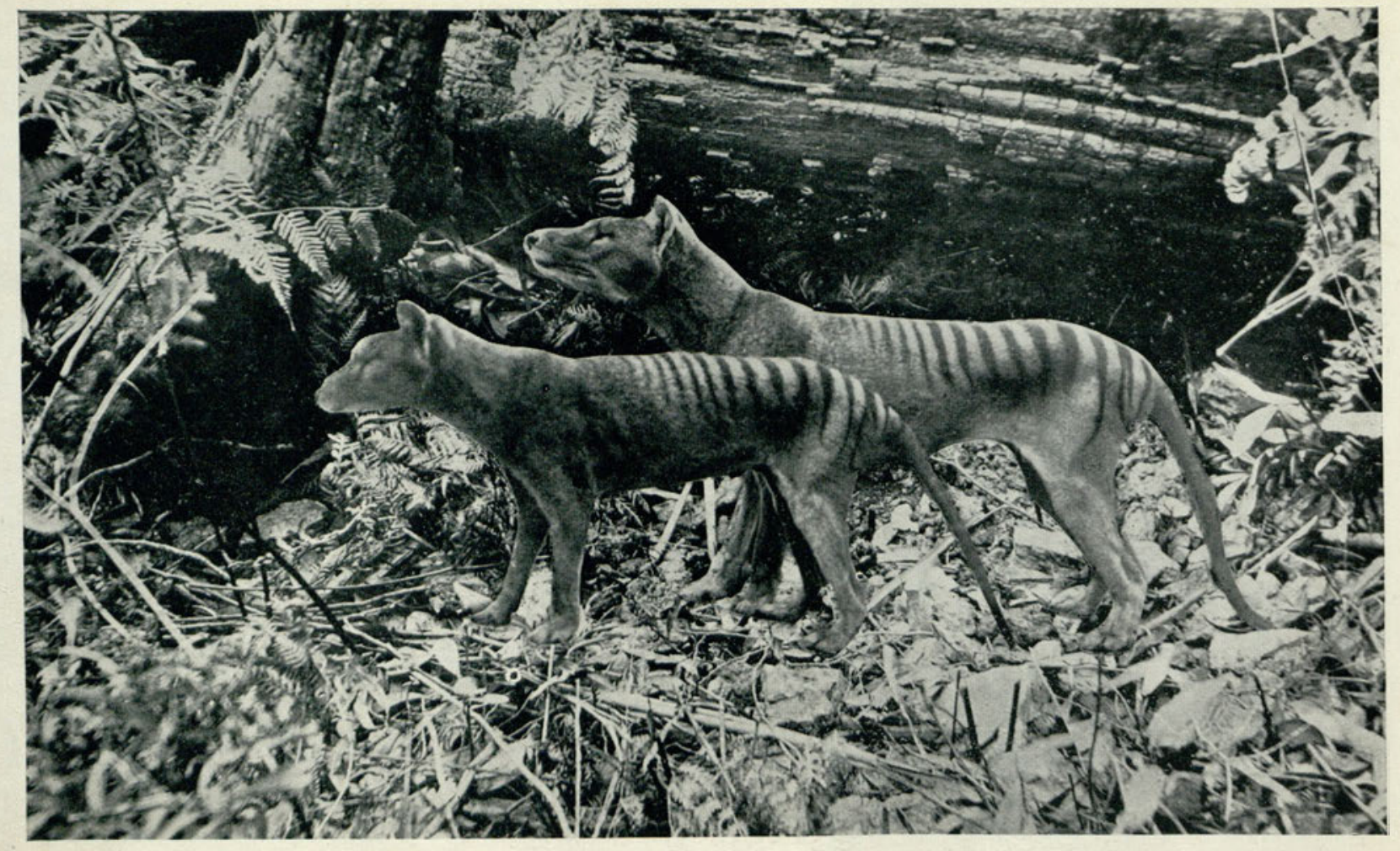


species, and which one is almost forced to conclude was introduced in bygone days by man, and has since thriven as so many other importations have done in Australia-unless he crossed from Asia by some land bridge.

As in other continents, some of the fauna of Australia attained huge dimensions. The remains have been found of a giant kangaroo, which does not appear to have differed in any respect from its present relative except in point of size. But a far more interesting creature is, or was, the Thylacoleo carnifex, or marsupial lion, whose nearest living relative is the Tasmanian devil. The bones of this extinct monster have recently been discovered in the fluviatile deposits in the Darling Downs in Queensland, and from the number of these remains found close together it would appear that they were overwhelmed by some sudden drying of the ground, such as sometimes occurs, with fatal results to beasts and birds, even now in this part of the world. For Queensland weather is singularly rapid in its variations, and as the Bushman says in his amusing Farewell:

"Here it never rains in reason,

There's droughts one year and floods next season."

Concerning the results of these sudden changes I shall say more later on. For the moment I will only say I was shown a piece of dry land which for months had been a large lake and which had dried so suddenly that, I was told, many black swans had been caught in the hardened soil, where they rest for hours after feeding, and were found dead there one morning, having been unable to get away, and having died of exhaustion from struggling to free themselves. 


\section{WANDERINGS IN QUEENSLAND BUSH}

In some such way these extinct lions may have perished.

As regards their nature a great controversy is at present raging over the remains. Professor Owen takes the view that the teeth show that they were intended to hold struggling prey; Professor Flower, on the other hand, declaring that the teeth point inward and slope together, as in the case of the kangaroo, showing that they were intended for tearing roots and fibres of plants. To this Owen responds that the front teeth do not meet, and therefore could not grind vegetable food, but were pointed for the purpose of holding and piercing struggling and living prey. He further points to the strong muscles attached to the head, which are only found in existing carnivora; and upon the whole he seems to have the better of the argument. However that may be, several species of marsupials have developed into carnivora in the course of ages, though remaining marsupials. Of these perhaps the most interesting is the Tasmanian wolf (Thylacinus cynocephalus), which is on the verge of extinction and is now confined to a very small district in the interior of Tasmania. I travelled far and wide to try to see this creature as it really lives, and when in Tasmania called upon Mrs Roberts, who has made almost the only attempt so far to perpetuate this most interesting creature. This lady, ${ }^{1}$ though nearing ninety, has formed a small $Z_{0 o}$ in her own grounds at Hobart for the purpose of saving the most interesting native species, and she showed me the only remaining live specimen of this extraordinary animal she now possesses. I watched it during a whole morning,

1 This lady has since died. 
and thought it looked a cross between the dog and cat families, with a very large head, and extremely thin body, which looked too slender for the huge head and which tapered very gradually into its long tail. It moved slowly in the daytime and looked bored and uneasy. Mrs Roberts told me she originally possessed a whole family of them, but only one now survives. She added that she thought both the Thylacine and its relative the Tasmanian devil might be induced to breed in captivity if she could procure suitable food for them, which should if possible be living ; but if not, should consist of lambs that had died or been killed. It seems a pity that this lady should receive so little encouragement in her efforts, for unless something is speedily done both the Thylacine and its relation the Tasmanian devil will shortly be amongst the things of the past. I later on called upon the curator of the museum at Hobart, but he told me the same story, and added that he and others were trying to induce the Government to establish a reserve in the wildest parts of the interior, which, though beautiful, were of little use for cultivation; but that the difficulty lay in the fact that the Thylacine, having acquired a taste for lambs, would travel far in search of the dainty, and was always shot at sight by farmers ; while on the west coast - the mining district of Tasmania - the miners cannot be induced to refrain from shooting anything they can get. He hoped, however, that something might shortly be done in this direction to save the hunted remnant of this most interesting animal. I may add that Mrs Roberts calls her specimen a hyena, on account of its odd laugh, uttered when the animal is in a rage; otherwise it usually emits a sound like a grunting growl. 


\section{WANDERINGS IN QUEENSLAND BUSH}

The Tasmanian devil is the only surviving relative of the Thylacine, and like it is nearing extinction, though more plentiful at present. This animal (D. ursimus) possesses the temper which has given it its name, and seems to resent even being looked at. Both these animals are Dasyures, being related to the animals known as native cats, which, however, are not cats at all, but more like our martens and polecats in the old world. One of them (D. maculatus) is of a lovely pale fawn, with delicate spots, and all the family have the carnivòrous habits of the weasels, as well as their wariness; but in spite of this they are all marsupials, and indeed it seems as if no Australian animal is able to get beyond this stage.

Yet, all other things being equal, it is easy to see how an animal which carried its young would go down before one which had only itself to look after until any pressing danger was past, though one wonders what was the actual cause of the extinction of a huge monster like the giant kangaroo (Palorchestes Azael), which stood about fifteen feet in height and must have had plenty of grass and leaves for food; while he could not have had many enemies at the time in which he flourished in his native wilds. Even granting the dingo to have existed at the same time, this animal could not seriously have menaced any but the very young of the species, for even the existing kangaroos do not fear him much, and the huge leaps of a full-grown kangaroo when escaping from some danger must have been trebled at least in the case of his huge relation.

From this enormous beast it is a far cry to the tiniest mammal on earth, the wee pouched mouse, a creature like a dormouse, of a delicate pale yellow, 
and so small that several can be held in the hand at the same time. Besides this beautiful little creature there are several species of mice and rats in Queensland belonging to the marsupials, while the mole found there is of the same great family. Truly Australia is the land in which to observe the ways of creatures long extinct in newer parts of the world.

Another very interesting animal is the platypus, which I found still existing in some numbers on the rivers or creeks of Central Queensland, though retreating before the white man. This mammal and its relation the spiny ant-eater are probably the last monotremes now living on the earth. There is a variety of the ant-eater still found in New Guinea with three toes, while the Australian kind has five.

The female platypus lays a white egg in a hole in the bank of one of the streams in which she lives, and hatches it out, after which she suckles it as other mammals do their young; but in the case of the still lowlier ant-eater the female, after laying her egg, hatches it in her pouch, after which she carries the young one till it is able to fend for itself. The ant-eater is still common enough in Queensland, and $I$ have seen one taken alive and put into a box. But even this humble creature resented being in captivity and wandered perpetually about the box looking for some means of escape.

By sitting quite quietly on the bank of the creek it was possible to watch the platypus coming out in the evening and swimming about after the manner of the water-rat, and now and then there would be several of them playing about, or what appeared to be quarrelling, but as they have very little means of injuring each other no harm was done. Being 


\section{WANDERINGS IN QUEENSLAND BUSH}

extremely shy creatures, they disappear at once at the suspected approach of man; and it will be a great pity when the last monotreme passes away from its present-day haunts.

The most typical animal of Australia is undoubtedly the kangaroo, of which there are still a good number left, and happily, in many parts at least, they are not interfered with, not being now in sufficient numbers to do much damage. A good kangaroo fence round a "paddock" meets the difficulty of keeping them out, or if a few are enclosed in these huge paddocks they do little damage to crops. Many of the paddocks are hundreds of acres in extent, and here the animals live very happily, going about in groups, except in the case of old men kangaroos, who are often found feeding in solitude. So tame do kangaroos become if they are not molested that they seem to like the neighbourhood of man. I remember, for instance, a huge paddock which enclosed a small herd of kangaroos and wallabies. One corner of the fence ran beside a road, along which people occasionally rode or walked, and it was often possible to see one or more of these animals sitting or lying near the roadway watching the passers-by with the greatest interest. Indeed, they had worn a pathway in their efforts to follow and watch any human being who came by, and on one occasion I saw one lying down in the hot sun, only lazily turning his head to watch me till I got out of sight. There was a stream running a short way off, bordered with thick currajong-trees, and if he had chosen to do so he could easily have taken refuge beneath them and been out of sight; but he chose instead to lie there, for the purpose apparently of seeing from his corner 
all he could of the road and any human life which passed along it. This inquisitiveness I have often observed in wild creatures when they dare display it towards man.

Kangaroos, I find, are far more afraid of a man who is walking or riding than of one who is driving, having apparently found out that when in a vehicle he is less dangerous-from an animal's point of viewthan when he is free to leave the highway, and this holds good of all the wild animals in Australia as far as I could notice.

Settlers distinguish several varieties of the kangaroo family, such as wallabies, whiptails, etc., besides the beautiful tree-kangaroo of Northern Queensland, which lives at the tops of tall trees. It has been noticed that the same species of tree is always chosen, and the tallest of these, and when at rest the treekangaroo sees to it that every leaf and twig which might obstruct its view of the country below is carefully removed. Unfortunately this animal also seems doomed to disappear before long, as its haunts near the Atherton Tableland are being rapidly cleared for the occupation of man.

Besides the question of size, the main difference between kangaroos and wallabies is that in the latter the interspace between the nostrils is hairy, while it is naked in the kangaroo; but settlers profess to distinguish several other minute differences. I could not observe these myself, though, as a rule, wallabies seem to me to be slightly darker than the average kangaroo. Both species seem to be gentle, harmless creatures as a rule, and easily tamed, and seem to get very fond of their owners. Indeed those I saw were not in any way confined, choosing to remain with 


\section{WANDERINGS IN QUEENSLAND BUSH}

their human friends, though sooner or later most of them find their way back to the wilds. They always remind one of hares with their gentle, bright brown eyes, and follow their owners about like dogs, greatly enjoying a game at times.

Another animal which is often made a pet of is the native bear, called koala by the natives. I saw several of these which had been taken from their wild state in youth. Usually this is done when felling a tree, when the sleepy mother is thrown to the ground from a great height and usually killed. Though a marsupial, she carries her young one on her back, and this partly protects it during the fall, so that, though usually stunned, it is living when found, and easily tamed. But though it makes a. very charming pet, owing to its softness and beauty, it does not always possess a nice temper, and hates being disturbed while sleeping during the daytime. It belongs to the sloth family, and likes to hang downwards and rest during the day, and I have seen a tame one bite its owner savagely if petted while at rest. It is said, too, that it cannot live unless it is fed on young gum leaves, but I know of one at least which is kept in a town and fed on bread and jam, and it looks most strange to see it sit up holding the bread in its paw and eating it. This young bear has lived with its present owners for eighteen months, but sooner or later the bears usually die somewhat suddenly unless they are allowed to return to their native bush when they wish to do so.

The slaughter of bears has reached such proportions owing to the value of their fur that unless carefully protected they also will soon become practically extinct. In one year alone (I9I9-I920) 
over a million bear skins were sold in Sydney market alone, while no less than five and a half million opossums skins passed through the same market that same year, though they had probably accumulated during the years of war; this would partly account for the frightfully high figures, and though nominally protected for a time there seems no way of doing so effectually in such a thinly populated state as Queensland. At any rate, I saw numbers of traps set for opossums in trees where their tiny nail-marks were found betraying their presence in the holes above.

One method of getting them is to go out with a gun at night and stand on the shaded side of a tree. As they always try to put the trunk between themselves and danger, it is easy to see the shine of their fur against the bright moonlight, and so to shoot them whenever they stand out for a moment beyond the trunk ; and in this way their numbers are rapidly diminishing. But these also are easily tamed, and I know of one large garden at least, in the neighbourhood of Sydney, round which houses sprang up so rapidly that many wild opossums were enclosed in a suburb before they had become aware of their danger. In this case the original bush has been left undisturbed for a distance of several acres and surrounded with a wall; and on moonlight nights it is easy to see and watch the playful little animals amusing themselves by running up and down the trees; and indeed if people would only realise the pleasure to be derived from seeing the wild things as they live at home, perhaps they would do more to preserve them for future generations and to prevent these interesting creatures from vanishing for ever from the earth. 


\section{CHAPTER IV}

\section{DINGOES}

Even now it has not been finally settled whether or not the dingo can be truly classed as an indigenous Australian animal or whether it was introduced into Australia in far past days by man. If so, it must have been very long ago, for where human remains have been found dingo remains are almost always found of the same period. But, on the other hand, there is no other large mammal of undoubtedly Australian origin which is not of the marsupial family. At any rate, at the present time the dingo has become so completely naturalised that it has formed a fixed type of its own.

I was once invited to take part in a dingo drive, but I refused. The fact is, I owe so much to dogs that, for their sakes, I do not care to injure any of their relations. Possibly if I were a pastoralist, and had suffered heavy losses from their depredations, I would feel differently; but as it is I think of the truth of the great French naturalist's saying that the dog is " the most astonishing, the most complete, and the most satisfactory of all the conquests of man," and for the sake of the dogs who have been my friends in the past I will not take part in their destruction, be they wild or tame.

At the same time I realise that the dingo has become so firmly established, and in such numbers, that in places it has become impossible to keep sheep 
for the present, while the skill and wariness of the red dog make it difficult to trap him; and this is rendered still more difficult sometimes owing to the assistance he receives from a tame dog. A number of good stories are told by settlers on this subject, some of them well worthy of the pen of a Jack London. One such I really must set down.

A settler of my acquaintance " out West " on the Cooper had a very fine kelpie or blue sheep-dog. Now it often happens that the settlers' dogs at certain seasons of the year get very anxious to pay visits to their wild neighbours, and it is difficult to restrain them as they cannot always be kept up, as they are required to help with the sheep. This kelpie accordingly always managed to get away sooner or later, and was away more or less for five or six weeks, after which he would return and be as well behaved as usual. Sometimes he would show signs of fights on his return, and once at least he came back with his ear torn right across; but at such seasons even the red dogs do not often kill the tame ones as they usually do if one of the latter tries to join them at any other time of the year.

Presently dingoes with very distinct traces of kelpie blood began to be seen about the neighbourhood, some of them being almost more blue in tint than red; and after a time it was noticed that the kelpie was becoming more and more unsettled in its habits ; but sheep-owners and their men are busy folk and there was no time to trouble much about the idiosyncrasies of a dog, so he was left to go his own way, until at last he altogether disappeared from the station. After this it was found that the dingoes in the neighbourhood were becoming more and more 


\section{WANDERINGS IN QUEENSLAND BUSH}

damaging in their depredations, and also were learning to avoid the traps more and more skilfully. No poison, however well placed, was eaten, and the lambs were disappearing in growing numbers. At last one of the shearers told a story of having noticed several dingoes being led by the kelpie, who himself sat at a safe distance and directed operations, giving warning when any danger threatened his mob of wild dogs, but never approaching too near his old home.

After this a watch was set, and one moonlight night a red female dog was seen in one of the paddocks going from sheep to sheep and tearing them in sheer wantonness; this is somewhat unusual, as dingoes do not generally care to stay longer than is necessary in the neighbourhood of man. A closer watch showed the kelpie sitting on a hill beyond the flock, and in an instant he had uttered a warning cry, but too late for the bitch which had paid the penalty of her crimes. The kelpie, however, had made off and for some days did not return. After a while, however, he again ventured near, and a large reward was offered for his scalp; but all efforts to catch him were in vain, until at last one day he was caught in a trap set for another dingo, far from his usual haunts, falling a victim to the bait of a poisoned sausage, which had been his favourite food in the past. Thus at last he had reaped the fitting reward of his treachery towards his old master.

I noticed that tame dogs in the less settled districts nearly always showed more than a trace of dingo blood, and I am assured that sooner or later any strain of dog reverts more and more in type to the wild red $\operatorname{dog}$; and the misfortune is that in most 
cases the mixed breed is shown sooner or later to reproduce the faults of both species; while a dog from another country or a town in the south will almost go mad at finding himself in the near neighbourhood of a mongrel; but the mixed dog, as beforementioned, does not dislike his wild brother more than two strange dogs of, say, the terrier breed in England do if thrown together for the first time.

Rewards are offered in most states for the scalps of dingoes, and I saw two such scalps brought in, which obtained the reward of ten shillings each, and which exactly resembled the collies of Scotland in every respect. I measured the heads, which were of blackish tint mixed with fawn-colour, and found them to reproduce in every particular the heads of our tame collies, though the bodies were more wolf-like in shape. In this case they were undoubtedly the result of a cross with some sheep-dog. I also saw several puppies brought in on one occasion which had formed part of the same litter found in a hollow log. There were four of them in all, two of dark markings and two of the red type, and all four were the prettiest and most playful little creatures imaginable. The two red puppies were adopted by a neighbouring settler to be trained as sheep-dogs, but he assured me that they would probably prove a failure, as sooner or later they were almost sure to "go dog" on him. Besides, it is difficult to make good sheepdogs of the wild dogs, for though they round up the sheep well enough they seem to have an incurable habit of biting the running sheep. I afterwards stayed in a house where a half-wild dog was kept, and in this case also, though he was very fond of his mistress, he was never safe with anyone else, and was 


\section{WANDERINGS IN QUEENSLAND BUSH}

very apt to bite anyone if an eye was not kept on him the whole time; indeed it was never safe to let him get behind one. The last I heard of him was that he had slunk out into the roadway one evening and, after lying in wait, had managed to bite a passing stranger; after which he was done for.

Sheep-owners can always tell what animal has attacked their sheep from the different habits of their enemies. Thus a crow will always attack the eye of the sheep, a fox will tear out the tongue, while a dingo goes for the liver. It may be mentioned here that foxes will not usually condescend to eat rabbits in Australia, but always go for sheep if possible, and the fox there shows differences from his English relation, for his nose is blunter and he is of a finer shape and size; in fact, he is drawing nearer to the dingo in appearance and structure, for the dingo has the same bright hue and the same beautiful brush.

In bygone days when the black men roamed these plains they had a custom, when a man died, of catching a young dingo if possible, and after cutting him about a good deal they fastened him to the grave of the dead man and left him to die. If he was eaten by the wild dogs they imagined the dead man was safe in heaven, and as it is usual for the wild dogs to eat any animal they find recently dead it may be concluded that most black men go to their heaven in safety. They are said to keep up the custom in the north and west, where there are still a good number of aborigines in their native state.

Numberless traps have been tried for dingoes in various parts. One I recently heard of consisted in smearing a well-known dingo track with treacle 
mixed with arsenic, and the very next day the dingo which used it was found dead. He had found the treacle sticking to his feet and had licked it off, swallowing enough arsenic in doing so to kill himself. This dingo had had a sum of one hundred pounds set on his head owing to the skill and daring of his depredations.

Occasionally one reads in the local papers of some strange beast which has been caught and which is described in the paper. But I wonder if these are not cases of some cross-breed between a dingo and a tame dog. For instance, the following appeared in a Queensland paper in August I92I :-

\section{A STRANGE ANIMAL}

PARTICULARS of a very strange animal which was killed in the Riverina district recently are given. . . . Mr Phelem, who poisoned the beast, said that it had been a plague for a number of years, had killed over a thousand of his sheep and he had laid $£ 24$ worth of strychnine in the effort to poison it, being under the impression that it was a raiding dingo. Apparently it never returned to a bait, but always killed a fresh sheep, and was never seen during its raids until found poisoned but still alive. When $\mathrm{Mr}$ Phelem poked a long pole at the animal it snappedat the pole and the tusks went through it as if it were soap. He would have sent it to the $Z_{0 o}$, but the stench was vile.

It had a long head, with very strong jaws, leathery face, the same as a monkey's, four tusks, two on top and two on the bottom jaws. The top ones were a little over two inches long and the bottom ones were much worn. The neck was about Io inches long, and very powerful, with brown bristly hair along the back, with white stripes half-way across the sides. The chest, stomach and hindquarters were leathery, with no hair. It stood $3 \mathrm{ft}$. $6 \mathrm{in}$. high, $4 \mathrm{ft}$. along the back, which was about I 8 in. wide, the tail about I foot long, with a brush like a cow's, foot as broad as a man's hand, with powerful claws about 2 in. long. Its ears were like a dog's, with a V-shaped piece taken out of both of them. 


\section{WANDERINGS IN QUEENSLAND BUSH}

\section{The comment made is :}

"The worn tusks suggest that the animal was very old, the black leathery appearance and 'vile smell' that it was badly affected by some kind of mange. If it has not been destroyed some effort should be made to preserve the skeleton for scientific purposes."

During the recent fearful drought-which lasted from I9I 8 to I $22 \mathrm{I}$ - the dingoes lived well, feeding on the numberless carcasses of sheep and cattle which died in vast numbers, faster than the cattle could be killed to lift their hides, and the wild dogs are said to have increased in proportion to the quantity of food. But this state of things is over for the present, mercifully, for a more terrible sight could hardly be imagined by anyone with a spark of mercy in him than the sufferings of the poor patient animals dying of hunger all over the withered plains. Water could be had, owing to the bores, but of what avail was water when there was not an edible green leaf for many thousands of miles?

The natives tame the wild dogs, which share their little all with them, and it is easy to see by this the way our prehistoric ancestors first induced the wild dogs or wolves to come in and share the fire of man, and to transfer to him the obedience and loyalty which belonged originally to the pack, and have made the dog a proverb for fidelity all over the world.

It is often said that the dingo is cowardly, but it is easy to understand the feeling of one who knows that the enemy holds all the cards, as the shrewd dingo undoubtedly knows well enough. It is said, too, that when in mobs the dingoes will even attack a man, but I never heard of an authentic instance of this. However this may be, it is difficult to understand how any wild dogs can be truly cowardly 



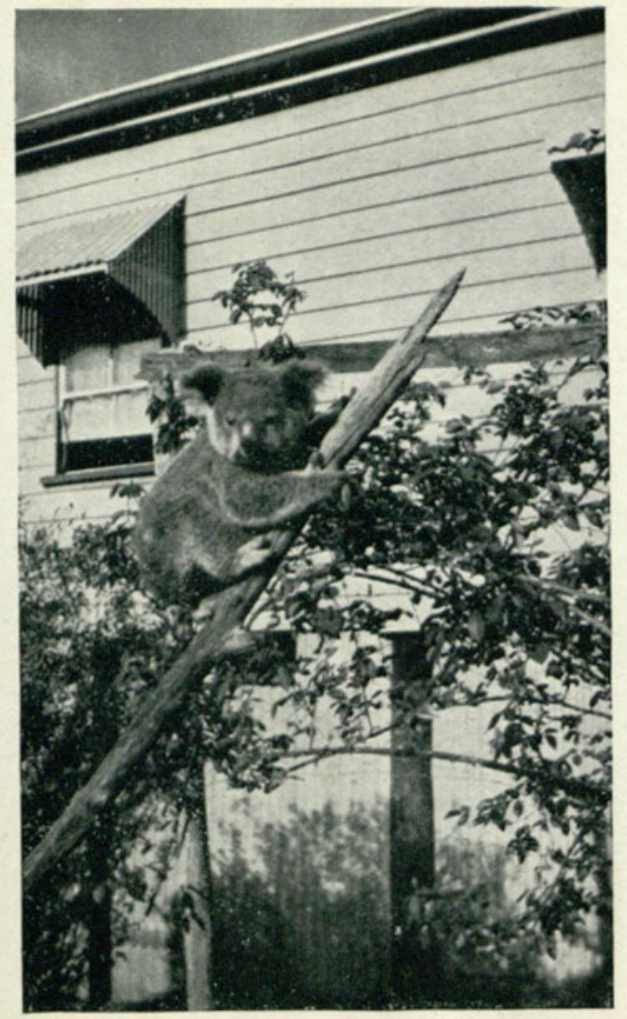

A YOUNG KOALA

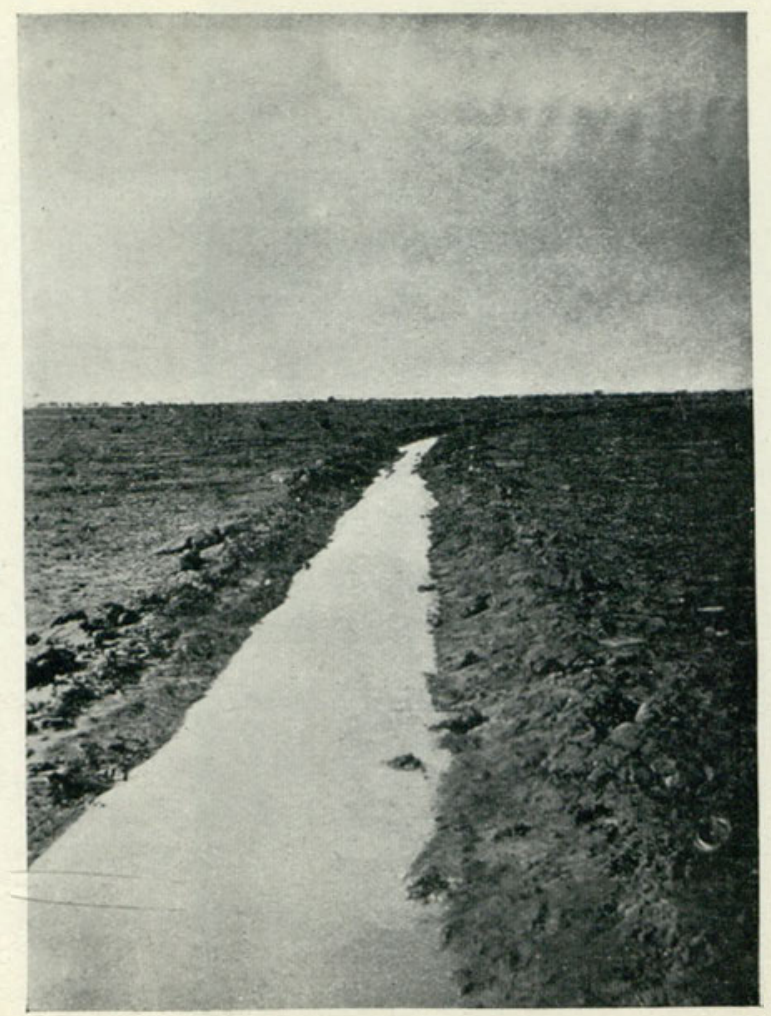

DROUGHT 
when one reflects that, in proportion to their size, wild dogs in almost every part of the world where they are found are noted for their courage. But even if this is so, when one reflects what tame dogs are to man, I cannot prevent a feeling of horror at the slaying of any of his family, even though this may be necessary in the cause of progress.

If the dingoes were not introduced by the primitive inhabitants of Australia they must apparently have crossed with those from Southern Asia by some land bridge now lost. At any rate they have established themselves there for long centuries it would seem. Upon their arrival they would find themselves in a land of plenty, for there were no other wild animals which could compete with them, while the other wild things provided them with plenty of food. At that time the marsupial wolves and devils were abundant on the continent of Australia, and these must have fallen an easy prey to the new and better-equipped mammal which had appeared in their midst, for the Thylacine is sluggish in its movements compared to the wolf family, from which the dingo must have originally sprung ; the native " cats" wereable to save themselves by climbing into the trees, and so escaped and survived down to the present time; but the poor native wolves were soon disposed of, and there only remained to them the island of Tasmania, which was cut off from the mainland before the dingoes made their appearance in Australia; and so well did they flourish that, at the time the early white settlers came, the country was overrun with them. Even at the present time, though their numbers are sadly diminished and they are gradually retreating before the white man, they 


\section{WANDERINGS IN QUEENSLAND BUSH}

still keep up the unequal contest owing to their skill and wariness.

Another curious thing about the dingo is that, in every instance I have heard of where a dingo has been tamed, it has remained with its master until it has been in most cases destroyed by its owner owing to its habit of biting the sheep; but for some reason it has not voluntarily gone back entirely to the wilds as most of the other tamed animals of Australia do ; no doubt there are instances of the dingo doing so, but I merely mean no such case came under my notice. On the other hand, far less wild creatures usually return sooner or later to the wilds, however tame they may have appeared, and however kindly they have been treated. Thus a native bear which had been kept by some friends of mine from its youth for some months, and lived in an orchard near the house, being fed daily on young red gum leaves, climbed down from its accustomed tree one night while I was staying with them and returned to the bush near, climbing the fence in order to do so, and was not seen again; this they assured me is the usual way of the koala sooner or later.

Again, I knew of one settler who brought home four young foxes which he tamed and kept in his stockyard. They became very affectionate and followed him about the yard ; but when the "call of the wild" came to them they tunnelled under the fence one night and made earths for themselves in the bush near. One was so near that it and the mate it found could easily be watched from the yard, and for some time it came back to be fed ; but gradually it grew more wild and would not allow itself to be approached, and at last, when its cubs were 
grown, it removed into thicker bush some way off, and finally did not return. A nest of young emus provided the same experience; for when they were grown they became more and more wary, and one day, finding their opportunity, they left the home where they had been brought up and disappeared, not to return. The tamed dingo, on the other hand, seems to retain its affection for its master, though its wild nature makes it an uncertain animal to keep, for it will bite almost everything but its master when it gets the opportunity.

A curious habit the dingo has learned is to "go dead " if cornered, and the poor brute will keep up the pretence even when its head has been broken. Some cases are known where such an animal has been left for dead, with its head half cut through, but during the night it has managed to crawl away into its native haunts to die in peace without having given one sign of life during the whole time it was being done to death. This would seem to need one kind of courage at least.

Probably if there were no species of tame dog trouble would be taken to tame the dingo, and within a few generations much might be accomplished, for the dingo has great gifts ; but as so many species of dogs are now tamed there is no need to tame yet another variety with some trouble; so the dingo will be left to carry on his contest with man until he disappears. But at present it is getting difficult to say - in the settled districts at least-where the true wild dog ends and the tame one begins, for, as before mentioned, many, if not most, out-bush station-dogs show traces of dingo blood, while an increasing number of the wild dogs show more than 


\section{WANDERINGS IN QUEENSLAND BUSH}

a trace of station-dog breed. So some of the wild species may survive in a modified form.

The usual view of mankind of course is that the world was made for man alone, and every other thing in it was to be of use to him or should disappear; but to anyone who takes the unusual point of view that it was originally designed for the use of many species, and not entirely for one, there seems a want of justice in exterminating any species merely because his territory is wanted by another, whether he be an animal or an aboriginal man; at any rate this would probably be the dingo's point of view if he could be consulted, and no one can deny the justice of it. 


\section{CHAPTER V}

\section{AMONGST THE GLASSHOUSE MOUNTAINS}

In all my wanderings throughout Queensland I saw no sight which impressed me more than the peaks of the Glasshouse Mountains. Even their name seems mysterious. It is said that they were so called by Captain Cook because they reminded him of the glass houses or glass furnaces in England when seen at a great distance out at sea ; others say it is because in the evening light they look like peaks seen through glass-which is true. At any rate, while most of the mountain ranges throughout Australia are not really mountains at all, but high tablelands, these are really peaks thrown up by some strange prehistoric convulsion of nature, and now they stand, weird and mysterious, all over the plains where they were thus thrown up countless ages ago. Their torn sides are of grey trachyte, and stand up, towering cliffs left in all their wild loneliness for the great benefit of the few travellers who wander amongst them, and who love Nature all the more when she is left entirely to herself.

These wonderful peaks still bear their native names, as is the case with many of the towns and villages of Australia, and this adds greatly to the picturesqueness of travel on that continent. One meets constantly such names as "Indooropilly" or "Woolamaloo," even near the large towns, while 


\section{WANDERINGS IN QUEENSLAND BUSH}

inland almost every name is of native origin, such as "Wondai," "Boowoogum," "Nanaango," etc. But it must be admitted that in the case of the Glasshouse Mountains the names take some pronouncing when it comes to Micketeebumulgrai or Tibberoowuccum. Two or three of them are near the railway, and can be seen during the train journey, but to be appreciated they must be seen from close by, and the longer one stays amongst them the dearer do their strange forms become. I have seen many mountains in many parts of the world, and some that are accounted amongst the finest, but I have never been so impressed as I was by the Glasshouse Mountains. I think it is owing to their loneliness, in some measure, and by a sense of mystery they possess ; but at any rate so it is.

I spent some weeks in this neighbourhood upon a new settlement begun by the Government for the benefit of returned soldiers. And here I must remark that, while many hard things are said of the Queensland Government-some of which seem to be deserved-these settlements are a noble attempt to pay back a debt of honour to those who fought and risked their all in the service of their country. The money spent on the settlements in various parts of Queensland may not always have been laid out to the best advantage, but no one can deny the honourable intentions of those in authority.

I visited several such settlements. In one place the site has been selected for the growing of sugar, in another for banana culture, and so on. The settlement in the neighbourhood of the Glasshouse Mountains is at a place called Beerburrum-meaning "parrot," in the native tongue-where more than 50,000 acres have been set aside for pine-apple culture. 
Here $f$ rooo is spent for each soldier who takes up land, no one receiving less than twenty acres of good land, which he must clear, and of which four acres must be planted with pine-apples; besides which he may grow anything else he desires, as some of the settlers have done. As in all such settlements, some succeed, though it is a hard struggle at first-particularly in cases where the soldier has no private means-while many fail. But the charm of the place to me lay in the fact that it was surrounded by virgin scrub, in which emus and kangaroos were still found, and could be seen quite close to the settlement, each house of which was surrounded by bush growing almost close up to the doors; while in every direction could be seen the weird, gaunt shapes of the mountains scattered about the plains. Added to which there was much swampy ground in the near neighbourhood which is useless for cultivation, and is therefore left to itself, and in which I was never tired of wandering; and between us and the coast was a vast stretch of " unsurveyed " land, too poor to cultivate, in which was a mob of wild horses which had long ago escaped and could not be followed, and which could now and then be seen running in huge circles. Being extremely wary, they are now left alone, as they would not pay to catch and tame. Now and then, it is true, a horse from the neighbouring "selections" joins them, and it is sometimes possible to "cut him out" of the mob if it is desired to do so; but those that have become really wild are practically useless ; therefore they are left to themselves.

If I were asked what natural object most attracted me in this district, besides the peaks, I should reply 


\section{WANDERINGS IN QUEENSLAND BUSH}

that it was the grass-trees, which grow everywhere, and which are so distinctive of Australian scrub. Exactly what it is which so attracts me in the grasstrees I cannot say, but as it was, I was never tired of them. I took countless photographs of them, of every shape and in every position, and I find there are at least two varieties of them in Queensland; one of which never seems to branch, growing in swampy land, while the other kind sometimes has several branches ( $X$. preissi). Both have flowering stalks exactly alike in appearance. These grasstrees - also called "blackboys" - are much used by the natives for various purposes. They make their weapons for fishing with the long, straight flower-stalks, which make excellent spear-shafts all ready shaped; they stick every weapon they use with the bright yellow acaroid gum which they extract from the root by pounding it. This by the way takes much time, and is done by the black gins, and until I saw a gin making it I wondered just where the gum came from which I found on every tool I got hold of. This same gum is highly inflammable, and one station-owner told me that before the war he knew it was being bought at the rate of $£ 60$ per ton from the natives. He now believed it had been used for explosives. However that might be, I found every part of a grass-tree to contain a great deal of resin, and it burnt splendidly and gave out a warm blaze; the natives use it for making fire when they have to light a fresh one, but knowing the time it takes to rub sticks for a blaze they take care when possible to keep their fires going, even carrying them with them when they make their gunyahs in a new place. 
It is interesting to see a fresh selector on his arrival. He first lives in a tent, and then sets to work to build a bark humpy. The trees all round are perfect for this purpose and there is an abundance of material everywhere. You can see at every turn such trees as stringybark, blackbutt, bloodwood and yellow bloodwood, ironbark, and many other kinds of eucalyptus-trees. In this humpy the "new chum " lives until he can build a house, with the aid of the older selectors; who also help him to clear the ground. This is done by ring-barking the trees and then leaving them to die, when they either fall or are burned in the next bush fire. It is a pitiful sight to see the huge monsters slowly bleeding to death. It seems incredible that so much timber cannot be turned to some account, even though the roads in Queensland make transport difficult. Considering the growing shortage of timber elsewhere, it seems a pity to see these huge trees dying or dead in every part of Queensland where trees will grow, even within a few miles of Brisbane. The roots are blasted out of the ground with dynamite, and altogether it costs about $£^{27}$ or $£^{28}$ to clear an acre of bush.

I loved to wander off into the swamp while the cool weather lasted. When summer comes no one would care to spend an unnecessary moment there, owing to the plague of flies and mosquitoes, besides which when the snakes awake they abound in every such spot in Queensland, and one must go warily if one does not desire to make a close acquaintance with them. But in the winter days, when the sun is warm and bright, but not too scorching, the swamp is a wonderful place. The paper-bark ti-trees grow 


\section{WANDERINGS IN QUEENSLAND BUSH}

closely together with their white stems, the bark torn from them in strips by the wild animals which roam there. Sometimes you may see emus walking by with their stately step, and kangaroos coming to drink, though they can live an incredible time without water if need be ; and overhead fly thousands and thousands of parrots, feeding on the white flowers of the ti-trees.

There are many varieties of ti-trees, which some spell "tea," owing, it is said, to the fact that they can be made into tea, but, having tried the drink made by an infusion of the leaves of several species, I must say that I would rather do without tea for the rest of my life than drink it made from any ti-trees I have tasted. At any rate the settlers know it as the ti-tree, and I always prefer the local names if possible.

Some ti-trees have beautiful red "bottle-brush" flowers, and some have flowers like trails of white may, and there are many other species; but most of them prefer damp or marshy ground and grow in close profusion there. The tall ti-trees in my swamp had flowers rather like orange-blossoms, but without scent. And I found throughout Australia that few of the flowers have any scent, or if they have, it is an unpleasant one; indeed sometimes it scents the air round most unpleasantly. The wattles are exceptions to this rule.

The parrots which were commonest in my swamp were the glorious king lories and the innumerable Blue Mountain parrots, or brush-tongued lories, with coats of blue and red with yellow markings, and they made the air gay by their brilliancy and vast numbers. They move northwards in dense flocks to breed. 
Another creature which moves northwards in vast clouds is a butterfly of the Pieris family. One morning the settlers in the Glasshouse region noticed a cloud overhead which darkened the sun, and found it to consist of white butterflies marked with black and tinted with pale yellow beneath. All that day these clouds passed, preyed upon by flocks of birds, and with their numbers thinned by many accidents. But nothing seemed to render the clouds less dense. That evening the flocks rested on the leaves and trees, and next morning they started again followed by other similar clouds. And this went on for three weeks, all through the hours of the summer daysfor it was midsummer in Queensland, being toward the end of December I 920 and well into January I92I. At last, one morning, the sky was clear again, and not a butterfly was to be seen; the multitudes had passed and left only a memory of the vast hosts behind.

Many creatures come out of the bush near the selections and only too often ravage the cleared ground. Where long lines of potatoes have been sown appear little holes, at regular intervals, made by the bandicoots, which seem to sniff the seed potatoes out unerringly, and often out of a whole row only one or two will escape, the rest having vanished, leaving only a line of holes. And kangaroorats are heard, jumping with a little ping, underneath the houses where the sacks are kept, for all Queensland selections are provided with houses, sooner or later, which are built on piles to protect them from the white ants and the snakes, which in spite of seven-foot piles sometimes manage to get in. And many other creatures get in too. Sometimes a hornet will build her nest near the ceiling, or a 


\section{WANDERINGS IN QUEENSLAND BUSH}

solitary wasp will build between the bedding and bring stores of maimed insects for her future family.

One day I found a dead wallaby near the house, though what had killed it I could not find out, but it had wandered quite near the house to die. This was the largest wallaby I ever saw, almost as large as a small kangaroo. As a rule, however, they kept at a distance of a mile or so from human habitations, though it was easy enough to see them in the wild country beyond the swamp, and I did not find that they feared me much as soon as they found I did not intend them any harm. I found that upon my making some uncommon sound they would sit up to listen, and even approach cautiously. And if I remained quite still in the long grass they would show no fear; but I often noticed how exactly they resembled their surroundings in colour, and even when I knew just where they were they looked so like the ant-hills round them that it was difficult to decide which were their backs and which the ant-hills.

Beautiful flowers and ferns grew in and near my swamp, and I loved them all the more because they grew for no human eye. There was the wild iris (Petersonia serica) which drops at once when picked, and the blue-tongue which stains the lips a deep blue. There were orchids too, a delicate white one with two long horns $(C$. alba); the red cotton with its yellow and brown spikes of blossom (A. curassavica), and the bush known as lomatia, with its white, sweetscented flowers so dangerous to flies, for if they settle upon the bush they perish owing to the prussic acid it throws off. This should make it of value to those settled in the bush where insects abound in frightful numbers. 
In the deeper shade cast by the swamp mahogany (E. robusta) - the ti-tree with white blossoms-grow lovely ferns, amongst them the five-finger maidenhair (A. formosum), the lovely pteris known as bat's-wing, and another, with the finest of fronds, like plumes, called $P$. tremula. Indeed it would be impossible to name a quarter of the beautiful things I found growing there. Such was its fascination that one day I ventured too far and was lost in the swamp. It was growing late when I discovered that I did not know where I was, and I tried one track after another in my endeavour to find my way out of it. For a long time it was in vain, for wherever I wandered I found myself getting into deep water and unable to go any farther. Again and again I found myself back where I had started, near a clump of lantana bushes which I had admired earlier in the afternoon; but the sun was sinking now, and I remembered tales of how easily one can get "bushed," and as the evening was growing chilly I began to wonder if I should have to pass a night in the swamp. How relieved I was when at last I managed to strike a trail made by some wandering horses or cattle!-for these are often left by the settlers to wander for weeks far afield in search of food, being expected somehow to keep themselves - and where cattle could go I thought I could, and by following this trail I found myself at last emerging into the late evening sunshine.

In the neighbourhood of the settlement there were numberless birds, and every day I discovered new varieties, for Australia is rich in bird life. I saw numbers of pigeons, flock and bronze-wings and beautiful little wren-warblers of blue and red 


\section{WANDERINGS IN QUEENSLAND BUSH}

colouring. There was one kind called fire-tail, which makes a nest like a stocking hanging by the toe, the eggs being placed in the heel of the stocking. Then there is the yellow-tailed tit, one of which built near the house a nest of two storeys, though what the upper storey is built for no one knows, as it never seems to be used. Willie wagtails, too, are very common there and build lovely cup-nests of mud of various shapes. Mud is not much used by Australian birds, I find, except those of the swallow family and the magpielark. This, by the way, is neither a magpie nor a lark, but a wood-shrike, though its exact position amongst Australian birds is not yet settled.

Perhaps of all the birds I saw in Australia I love best the superb warbler, with his brilliant coat of blue and black velvet. One male usually has four or five plain-coloured mates. He himself either sheds his coat every year or does not get it in perfection till he is about three years old; but this is a Western species. And here I must add yet one more to the complaints made as to the ugly names bestowed upon beautiful Australian birds and plants. Some names are curious or interesting, such as the noisy pitta or the bubblyjock-usually bestowed by unscientific people-but what about such names as the red-rumped warbler, the white-chinned honey-eater or the yellow-bellied grackle? The names bestowed by Australian naturalists upon birds have often been commented upon, and "Oriel" in The Argus has written most amusingly upon this subject as follows :-

\footnotetext{
"Sweetheart, we watched the evening sky grow pale, And drowsy sweetness stole away our senses; While ran adown the swamp the Pectoral Rail, The shy Hypotænidia:Philippensis.
} 


\section{THE GLASSHOUSE MOUNTAINS}

Dear, all the secret's ours, the Sharp-tailed Stint Spied though he will not tell, though you and I Paid Cupid's debts in Love's own golden mintWhile Yellow-bellied shrike-tits fluttered nigh.

The Honey-eaters heard; the Fuscous yes,

The Warty-faced, the Lumulated too, But this kind feathered tribe will never tell

What words you said to me and I to you.

That day our troth we plighted-blissful hour-

Beginning of a joy a whole life long ;

And while the whole world seemed to be in flower

The Chestnut-rumped Ground-wren burst forth in song."

One of the commonest of the butterflies in the swamp was the beautiful wanderer (Danais crippus), and this is perhaps the very commonest butterfly in Australia. I remember once in South Australia noticing all along a long line of bushes hundreds and hundreds of these butterflies at a time, fluttering or settling on the leaves; and so tame were they that they allowed us to handle them without showing any alarm. I also noticed them in profusion in the swamp, but never so numerously as that day in the south. And this recalls to my mind three pictures which I saw in Australia and which I shall never forget.

The first also concerns a butterfly, this time of a bright yellow, which I noticed one day hovering over a tree loaded with the golden blossoms of the wattle. It was a hot morning and the air was filled with the scent of the wattle, and suddenly I noticed a huge yellow butterfly, of the same tint as the wattle, which kept on fluttering and settling upon the flowers, looking himself like a flower which had taken wing. The brightness of the whole scene remains with me still. 


\section{WANDERINGS IN QUEENSLAND BUSH}

The second picture was another unexpected one, and therefore all the more striking in its effect. This time we had climbed the Glasshouse Mountain locally known as Wild Horse Mountain, and suddenly when near the summit I found myself in a perfect rock garden. How such brightness came to be in that arid spot, with almost no soil between the rough rocks, I cannot imagine. Gardeners who take endless trouble with their soils seldom attain such perfection of beauty as I saw that day. Wherever you looked you saw nothing but a sheet of flowers-almost all of white or yellow tint. There were snow bushes covered with white flowers in clusters, beautiful pale lemon wattle and ti-trees-usually moist-loving shrubs-in rich profusion also. There were great trails of lovely hoya climbing amongst the rocks, and white and yellow orchids, one common one being the beautiful $D$. sulphurea, and yellow and white heaths filled any empty spaces, while a climbing creeper of the honeysuckle and another of the wild rose families ran and fell over the rocks. How they obtained enough nourishment in that dry and rocky soil I cannot think, but so it was.

The third picture-and these are only three of many-was found in a grotto. This time I was climbing a dark ravine in the mountains, with only a small patch of sky far above. Suddenly, while I was resting on a fallen log beside a tumbling stream, where few green things grew, I noticed some thick vines hanging over the entrance of a tiny cave, and I thoughtlessly lifted the vines to look inside. There I saw upon a rocky ledge a beautiful fern growing, as if planted, and obtaining its moisture from the drippings of the rock above. Its long lace-like 



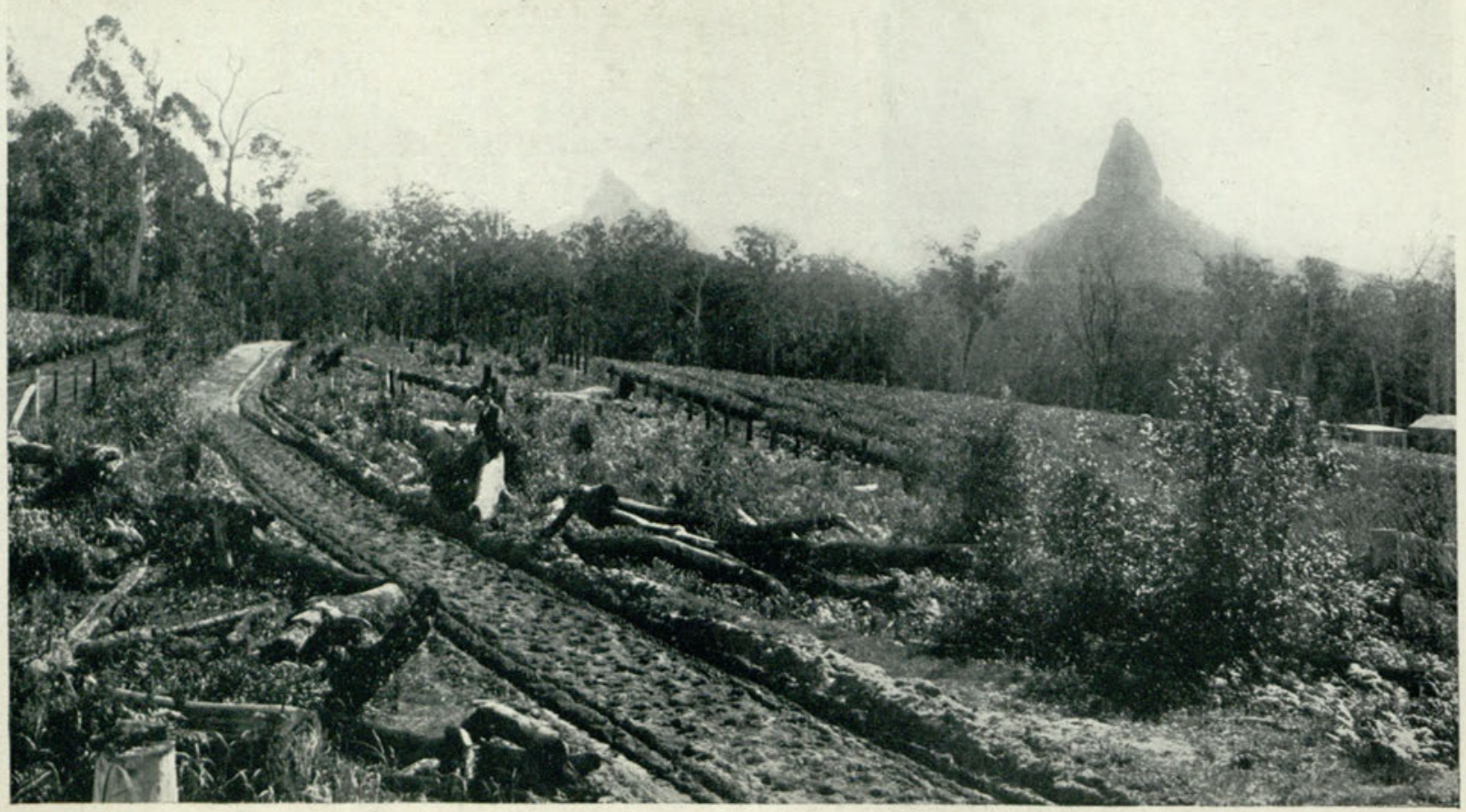

IN THE GLASSHOUSE COUNTRY - 
fronds hung far over, and even now I do not know its species. I only knew that probably no human eye had ever seen it, though it looked as if placed there by some artist for the sake of the effect it made standing out alone on the ledge in that bare place ; and indeed an Artist had placed it there, but not an earthly one.

One of the peaks of the Glasshouse Mountains is called by its native name, Tibberogargan, and this crag contains some curious-looking caves on its rugged face. The peak is so hard to climb that it seems strange that people should ever have lived in them, but the black men are said to have inhabited them in bygone days. They have lately been recalled to mind by a tragedy.

A few years ago a settler came into the district and prepared to clear some ground. He was known to be a moody man and few people cared to associate with him. He mostly had a whisky bottle for his companion, and often, when spoken to, he would become violent, and perhaps throw something at the intruder who had ventured near the camp-fire at which he sat in solitude. He was known to have come from "out west," and a story was told of a murder done there, and it was said that he had somehow escaped justice-an accident being allegedand he had then left that neighbourhood. As time passed the man got more and more morose, and at last he was left alone by everyone, and before long he gave up all pretence of working on his selection and took to the mountains. There he lived in a cave on the slopes of Tibberogargan, and nothing more was heard of him till his body chanced to be seen one day from below, lying on a ledge on the side 


\section{WANDERINGS IN QUEENSLAND BUSH}

of the crag. How he came by his death no one knew or cared, nor has anything more been heard about him.

The most wonderful mental picture of all I retain of my time in Queensland was the result of a picnic. Now a Queensland picnic is very different from the same social function in England, when the most serious mishap is the forgetting of the knives or a spider in the tea. In Queensland a picnic is a real adventure, and one never knows what may occur during the day. One of these functions I particularly remember.

The day was perfect, and it was resolved to have a picnic, and several families arranged to meet at a certain creek miles away across country. Early on the same day we all started off in various vehicles, sulkies, cars and spring-carts (meaning carts with no springs). All went well for a whilethe ravines and other obstacles on the road were no worse than usual, and it seemed as if we should all reach our destination without more accidents than usual. But my driver was of an adventurous turn of mind, as befits a pioneer, and he presently left the main road-which in Queensland means the slightly best track-and took to side roads with his car; with the result that, after partially passing a bridge made of logs over a stream, we came suddenly to a part of the stream, or rather river, where the logs stopped suddenly-and so did we, for the car sank into the water, which was there about three feet deep, the logs having been carried away by a flooda common enough occurrence in Queensland. We had lost sight of our companions by this time, and I was glad of it, as I did not wish to be seen by the 
rank and fashion of the neighbourhood in my present plight ; so we undressed as far as was necessary and waded ashore, after which we redressed and went in search of aid. After a long search we procured two horses and a set of chains, which most Queenslanders seem to carry when starting off anywhere, and after a long delay, during which we built a temporary bridge from some logs lying about, we managed to drag the car on to the bank. When we neared yet another log bridge, over another creek, my driver gallantly walked along it " to test it," as he said, but I informed him firmly at once that, whatever the results of the test, I did not mean to cross another $\log$ bridge. Finally we found a less adventurous mode of crossing the creek.

And after all the evening on such a creek is worth much discomfort, for the sun shines through the gums and lights upon the peaceful waters, and the deep reflections make a double picture in the golden light. No human sound breaks the stillness, and one turns away reluctantly from such a scene, wondering whether one will ever look upon it again, and glad to have seen it before it has been "developed "as it must some day be.

To return to my last picnic in the Glasshouse Mountains region. It was my last Sunday, and we started off across country in the springless springcart, and tossed and swayed as usual in crossing the trees and streams which fate had strewn in our way. Slowly we made our way to the foot of the most wonderful of the sardonic peaks all round us, the one which had always held my fancy from a distance. At last the cart could go no farther, and I walked on alone up the stony path and on past the one pine- 


\section{WANDERINGS IN QUEENSLAND BUSH}

apple farm nearest the base of the mountain, which is called in the native tongue Coonagrin, but which has been corrupted into "Crookneck." This wonderful mountain dominates the plain, and from almost every aspect looks like a gigantic candle set on end, though there is a slope on one side. There is a crag of thirty or forty straight feet of trachyte near the top, forming the cone of the mountain, which gives it its strangely impressive appearance, and suddenly rounding a bend in the track I came upon the peak -for once without any intervening trees. I shall never forget that moment. The sun was shining all round except for one dark cloud which hung just over the peak, and I stood there in silence, wondering what it was that rendered the mountain so impressive, when all at once the cloud lifted and the grey stone shone red in the dying light. Then after a pause it was covered again; but I had seen it for a moment, and the memory was yet another picture which will remain with me for ever. 


\section{CHAPTER VI}

\section{ON THE SEASHORE}

As the weather was perfect for " exploring," owing to the recent rains having cooled the air, I determined to go up the coast of Queensland with a few friends. So we hired a tiny motor launch for the purpose. First, however, we had to get to the coast from the interior, and for this purpose we hired a motor. I knew what Queensland roads were like, and I thought I knew what rains meant to them; but I did not realise all those particular rains meant. Mile after mile the motor plied wearily along, sticking here and there, and once at least having to be dug out by means of chains fastened to the rear, drawn by horses which we were fortunate enough to find not too far off, belonging to a lonely station. At last we reached a long slope, whose steep sides were scarred with ravines torn by the rains, while various forms of gums were lying about everywhere. The driver, however, thought " perhaps we could get up," and put his car bravely at the hill. For a while we struggled along with the car at an acute angle, sometimes lost in a rut and sometimes skimming along a tree trunk or two where these had been hastily thrown lengthwise into the deepest crevices in the road. But at last the gallant Ford had done its utmost, and the engine ceased to work, and after one or two hopeless attempts the car began slowly to move downhill backwards. 


\section{WANDERINGS IN QUEENSLAND BUSH}

As there was a ravine far below, with a stream at the bottom, and the road on the other side was hopeless even for a Ford car, the only thing left to do was to look out for a good place to fall into, and the driver steered with one hand while repeatedly looking round to see where he was going. We were all silent, there being nothing to do but to await events, as the car was gathering pace for the final plunge. But at the most critical moment fate intervened. As the car turned to leave the so-called road it ran backwards into the trunk of a tree which had fallen across the road, and under whose branches we had threaded our way as we came up, and with a wild jolt or two came to an abrupt stop. After this we determined to walk the remainder of the way, and reached the coast some hours later.

Once there our trials were over, and of the whole time I spent in Queensland this trip affords the pleasantest memory. My companions were of the best type as travelling companions, and prepared for anything; the weather was ideal throughout, and everything went smoothly till the end. Added to which the bane of my life in travelling-my luggage -was absent, I having taken the precaution this time to take nothing but what I could keep my eye on. I may mention here that until this trip I had tried to carry my possessions from place to place with me. In vain. One of my trunks, a yellow fiend, never stopped getting itself lost, until I began to have an uncanny feeling that the thing was alive and had taken a dislike to me. I knew it was of leather, and perhaps the animal upon whose back it had once grown was a vicious brute. However this may be, I never arrived anywhere during the 
whole of my time in Queensland at the same time as that trunk. Sometimes I would run it down in a day or two, sometimes it took a week; but I never took my eye off it for one moment without its taking the chance of getting away by itself. However, I have firmly resolved that if I ever get it safely back to England it will be pensioned off. I will never take it with me again.

Early next morning I was aroused by the carol of the magpies, and found the sun was rising in a haze of gold. So, early as it was, I got up and wandered along the beach. The sands stretched away for miles, and no human being was about. I could not help thinking how crowded such a place would be in England and congratulating myself that no tourists or bathing machines or children with spades were here. Every step brought some fresh pleasure. Here it was some beautiful shell, and it would have been possible to make a splendid collection in a very short time. One kind was the shell of the huge green sea-snail, which squirts a poisonous liquid over its prey and then bores through its shell and eats the victim. Another common species was the beautiful cowrie, of which there were endless varieties. One I picked up was banded with blue and brown, another was beautifully marbled with yellow and brown, while others were white with brown spots; indeed every one of them was different from the rest. Here and there were brilliant green oyster shells or pale pink spine shells, and innumerable others.

Now and then I came to groups of rocks, amongst which grew sea-anemones, while crabs of brilliant colouring ran here and there, and before I had to 


\section{WANDERINGS IN QUEENSLAND BUSH}

return to camp for breakfast I had seen the sun rising to the heights above in a cloudless sky.

Day after day we wandered along, sometimes on the sea and sometimes on the shore; but I always found something fresh of interest in every beautiful bay. Sometimes it was some disgusting-looking bêche-de-mer in a rocky pool, and sometimes a dead fish-perhaps a parrot-fish, with its hooked bill. Once it was a most curious fish, with square markings and a horned head with blue stripes-a colour of which nature is very fond in Queensland. One beach I found to be rich in a great variety of sponges, and another was covered with corals of various tints from the Great Barrier Reef. And the sea, with its beautiful islands, was a sight of which no one could ever tire, I think. Many of these were uninhabited, and were covered with palms or other trees, and between them and the land the water was of the. loveliest tints.

We carefully avoided towns, passing them as rapidly as possible and always choosing some lonely spot to camp for the night, and the billy tea made over a $\log$ fire was the best I have ever tasted, though it was sometimes smoky I admit. But the nights and their various sweet sounds made amends for anything.

One day I begged to be left alone for a whole day upon an island which had taken my fancy, and here I spent one of the happiest days of my life. All day I wandered with nothing but the wild things to keep me company and I could ask for nothing better. In the heart of the lovely island grew a profusion of pandanus palms, and suddenly I came upon a tiny lagoon which made me feel absolutely breathless 



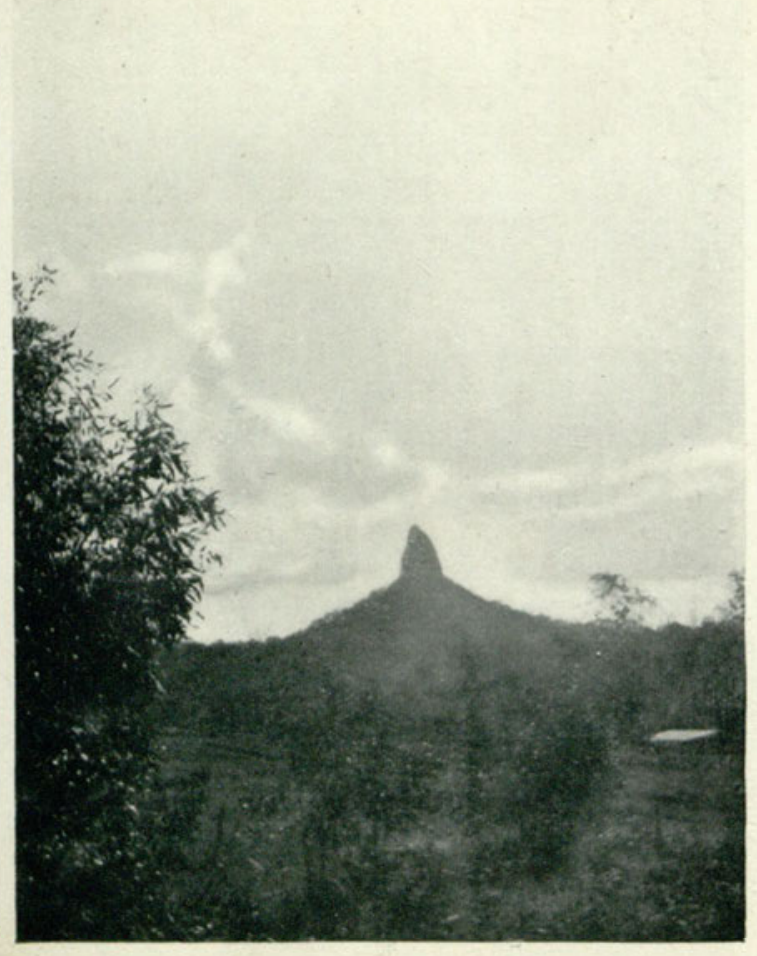

THE LONELY PEAK

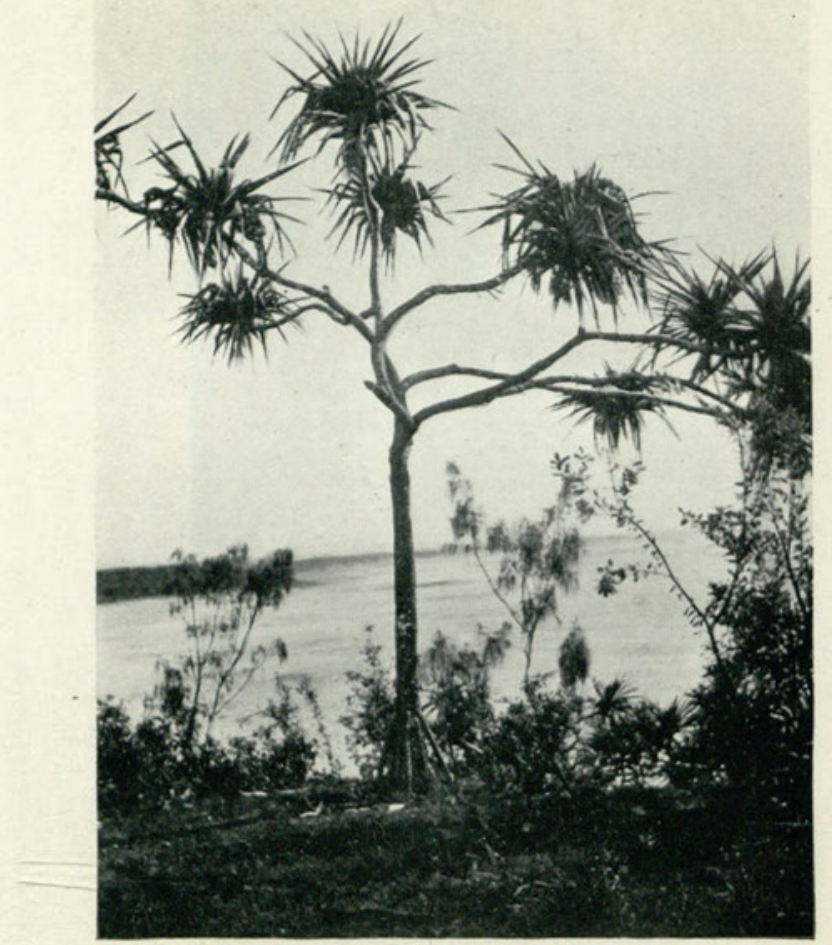

"QUEEN OF THE COLONIES" TREE 
with its beauty. The sands were of pink and gold, with dazzling blue water above which showed every little ripple on the sands below and the beautiful fish gliding about among the gardens of the sea. One sea plant particularly struck me, for the foliage was of green, but the fruit was like a soft green apple set in a scarlet cup. I waded in and picked one, but its beauty faded within a few days.

Numbers of mutton-birds flew towards their nesting holes on the mainland, and honey-birds were everywhere, and various parrots were feeding upon some flowering trees. Hour after hour passed, until I noticed suddenly that the sun was setting, so with great reluctance I turned back to the landing-place, noticing that, except those of the wild birds, no footsteps were to be seen but my own. Some of these lagoons are full of pelicans, snipe and cranes, and black swans are found in numbers near the coast, while curlews wail at nightfall from the flats near the shore, and great numbers of wild-fowl are here also. And in places the watercourses are absolutely choked with the beautiful blue water-hyacinth which is now classed as a " noxious weed."

One day near the beginning of our trip up the coast I came upon a tree bearing the inscription :

"QUEEN OF THE COLONIES," 1863

-and was told the following story concerning it. It appears that one of the crew of the above-named vessel had died and a boat was sent to the mainland to bury the dead man. Some hours later, as they had not returned, another boatload was sent ashore to look for them, but after wandering about for 


\section{WANDERINGS IN QUEENSLAND BUSH}

hours, darkness fell and they were forced to put to sea, the Queen of the Colonies having given them up for lost. Some years afterwards the above inscription was found by a landing-party, but none of the first boat's crew was ever seen again. It is supposed that they must have fallen in with some natives, but what their fate was one can only guess.

Another beach is called the "dickie" beach, from a wreck which still lies there. It was once a pleasure steamer and the iron awning is still up; but one of the sudden cyclones which visit the Queensland coast had blown it far up the beach and wrecked it, and now it lies, a melancholy object, with huge holes torn in its ragged sides which are the haunt of wild-fowl and gulls.

These sudden gales on the Queensland coast often do terrible damage. One which swept over Central and Northern Queensland three years ago was especially severe, and in the town of Mackay, on the Pioneer river, a tidal wave added to the disaster. Some friends of mine who had a house just outside the town were standing on their verandah, watching the water rising all round and listening to the rushing wind, when they found the roof of their house suddenly blowing off and being carried far into the air. People all round them were hurriedly putting together tables, etc., to form rafts, in case their houses gave way beneath them, for the water was rising to a level with the ground floor, covering the seven-foot piles upon which Queensland houses stand. At one moment a huge wooden bed, with the mosquito curtains still erect, was poised upon their garden fence, whence the next moment it was swept away by the wind and waters. One man was seen floating down the river on the wreck of a piano, and at one 
time they counted over forty dead horses and cattle in the field beyond the garden. Houses were being unroofed and carried away in every direction, and the church suddenly collapsed into a heap of ruins. It was vain to think of going out into the open, for no one could stand for a minute against the force of the hurricane, and during its course several huge tenders were swept out of the river and thrown against the iron bridge which spans it, carrying a good part of it away and being themselves swept, rolling over and over, up the opposite banks. Altogether the hurricane was at its worst from midnight till two o'clock next afternoon, during which it was impossible to make oneself heard owing to the noise, and by that time the tidal wave had risen about forty feet. When at last the wind and water abated, the town, like many others, presented a curious sight. In one street only one house remained intact, while trees, cattle and furniture were piled in endless profusion on the river banks.

Where the trees debouch into the sea there are often dense mangrove swamps running for miles, and one sees very strange creatures in them. I noticed multitudes of one-clawed crabs, which dug suddenly into the ground at my approach. These are much in favour with fishermen for bait, for there is excellent fishing in these estuaries, as they are full of such fish as bream, mullet, flathead, snapper, etc. ; but as a whole Australian fish are somewhat tasteless as compared with those of Europe. Still, a very fine afternoon's sport can be enjoyed with a line, and the knowledge that it will prove a welcome addition to the supper round the camp-fire at night adds to the pleasure. 


\section{WANDERINGS IN QUEENSLAND BUSH}

Some of these lovely lonely bays are perfect for bathing, and it is possible to walk far out in the clear shallow water; but it is not safe to venture into deeper water owing to the swarms of sharks which infest these seas.

I heard something of the multitudes of these terrible creatures from a Captain Borland whom it was my privilege to meet during my stay in Australia, and with whom I travelled for some weeks. He told me that there were several places round the coast of Australia used as breeding-grounds by sharks, and he once heard of a bet made by a fisherman that he would undertake to catch a thousand of themlarge and small-within a week. Upon visiting the bay towards the end of the week, Captain Borland was surprised to see two great mounds of sharks, and was told that nearly five thousand had been captured and brought ashore. Indeed the difficulty was how to dispose of the bodies, some of which were only a foot or two in length, while some were of great size.

This same Captain Borland-who was in command of the vessel in which I travelled-told me that many years before, while training in a sailing vessel, he had seen a sight which had impressed him greatly. They were becalmed off some rocks in mid-Atlantic when suddenly they found the ship surrounded by a mass of sharks which literally filled the sea for a long distance all round. One of them, "the father of all the sharks," as he described it, a huge monster, approached cautiously and bit the wooden hull of the vessel to test it in case of danger, and having pronounced it safe in shark language the rest swarmed round them hungrily. As there was nothing to do 
while waiting for a breeze, the sailors amused themselves by fishing for sharks with baited hooks, and drew them out of the water as fast as they chose. Once on deck the sharks were killed with hatchets and thrown overboard, when their late companions devoured the bodies at once. One of them which was brought aboard gave a lash with its powerful tail and threw down several of the crew, including Captain Borland, and by this time the decks were slippery with blood. This serves to show the vast numbers of these " sea-dragons," for they can have few enemies whom they need fear.

Another interesting creature on the Queensland coast is the dugong, the original of the mermaid, though its hideous face is little like the fabled beauty one had hoped to meet. This marine mammal is half-way between a hippopotamus and a seal in appearance and possesses a tough leathery hide. Its flesh is said to be good to eat, but one would imagine that it would be tough. This animal cannot turn its head and must come up to breathe, and it can then be seen holding its young one in its flipper, like a woman carrying a baby, and bringing it to the surface to breathe when the mother does so herself, and this gives rise to the fable, as the two seen afar off look rather like human beings. The dugong is an affectionate mate, but a more repulsive type of face is hard to imagine, with the hanging lower lip formed for gnawing the sea-grass upon which the animal feeds. It makes its home chiefly near the Great Barrier Reef, and is hunted by the natives for the sake of its meat, which is said to be like coarse beef ; and this will probably be its last haunt before it joins the long list of departed species. 


\section{WANDERINGS IN QUEENSLAND BUSH}

A walk inland from the shore takes one through lovely valleys, often bordering some lagoon and leading to a river or creek which in many cases seems to have no name. She-oaks hang over the pools, and lovely palms, of which I noticed several varieties. One of these is the cabbage palm and another is the graceful phœnix, while pandanus palms grow everywhere, with their golden fruit. One can wander beside some stream which winds through a rugged valley on its way to the sea and, unless the sides are too densely clothed with scrub, one can see new beauties at every step. Sometimes it is a group of tree-ferns growing to many feet in height, often to fifty or sixty feet, and making the air dark above them with the density of their foliage; or cycads, that great family of bygone ages, now represented by degenerate descendants, but still beautiful.

Cocoa-nut palms grow in some patches near the coast and one can see their graceful feathery foliage waving against the brilliant sky in the hot wind, and where the ground is open enough grow many lovely flowers. Along the coast the ground is often gay with the magenta flowers of the "pig face" ( $M$. equilaterale) and on the flats near the coast grow masses of beautiful boronias, lovely typically Australian flowers. Ground-orchids are everywhere -yellow and mauve varieties-and burchardias of many kinds. I noticed here, and even in the mangrove swamps, the painted lady butterfly (C. cardui), and this is yet another country where $I$ have found this ubiquitous creature. I have specimens from the Yukon, Central Asia, Natal and every country I have visited in Europe, and to find it in Queensland 
proves to me that it has established itself in every part of the world.

Another curious creature found in the mangrove swamps is the hopping fish (Periophthalmus), which " sometimes leaving the water climbs trees and looks all round it with its curious protruding eyes." This fish has a breathing apparatus in its tail, and is yet one more of the unique creatures of which Queensland is full.

The dense scrub is full of hanging moss falling in long trails, and calamus vines bind the trees in such tough fibrous folds that the plant well deserves its popular name of "lawyer vine" from the impossibility the encircled tree finds itself in of ever shaking itself free from the strangle-hold; and I noticed too the pretty shrub sarsaparilla ( $H$. acutifolia) and the evil-smelling snake-vine (Hibbertia), while many of the trees were infested with pretty parasites of the mistletoe family, or loranths, with red flowers and red or white berries.

Farther inland, where the ground is more open, one comes across lovely flowers or flowering trees. The silver wattle seems common in most parts of Queensland, and the quinine bush, with its clusters of brilliant berries, makes a pretty show, though not the true quinine of commerce. And in every part of Queensland are ponds, where beautiful lotus flowers grow, both blue and pink. One of the most beautiful is the lake near Longreach, covered with them, and along the coast there are numbers of such lakes, large and small. Truly it is easy to imagine that Tennyson had seen this land of "plenty of time" when he wrote of the country "where it is always afternoon," for it is easy to dream 


\section{WANDERINGS IN QUEENSLAND BUSH}

away many hours in idleness in that hot, drowsy air.

While on the subject of flowers I should like to mention some of the most beautiful of the native species. Perhaps the very loveliest of all is the Eugenia Hislopii, with its tufts of pale pink fluffy flowers, and the equally lovely fruits, of the same exquisite tint ; and indeed it is the fruit of many Queensland trees which give them a distinctive charm, such as the Sterculia quadrifidi, with brilliant red fruit lined with yellow and its bright black seeds. Another with the same colouring in its fruit, and equally beautiful, is $A$. vaillantii.

Lovely orchids are found in these scrubs, such as Cymbedium suava (yellow and brown in colouring), and on the hill-sides are found great clumps of the beautiful white orchid locally called " native lily," and hibiscus of various shades are natives of Queensland. The flame-tree grows in many places too, but this is another importation which has naturalised itself and therefore cannot be included amongst the natives; and the same must be admitted of the Magnolia purpurea or " wine magnolia," as the settlers call it, which I found growing in the wildest places. Once in the same way I found, when following a mountain stream without a name-as far as I could find out-a large clump of white irises which had grown there without being planted by men, for it was far from any white man's dwelling, but these also, like some aloes, have spread far and wide in the rich virgin soil, in the same way as some terrible pests have done in that too hospitable land; but feathery bamboos are natives and beautify many glades with their graceful foliage, and one must not 
omit the banksias, with their " bottle-brush" flowers, often of brilliant hues, and their extraordinary seedcases, which when the seeds have been discharged look like gaping mouths.

It was with the greatest regret that at last we turned south and retraced our steps along the Queensland coast, but it was getting very hot during the daytime, and the bush was getting full of insect and other pests, which warned us that we must linger no longer ; but the wild loneliness of those exquisite scrubs and valleys have left an impression on one's mind which it would be impossible to forget. 


\section{CHAPTER VII}

\section{SOME PESTS}

"Queensland, thou art a land of pests, For flies and fleas one never rests, E'en now mosquitoes round me revel, In fact they are the very devil. Sandflies and hornets just as badIn fact they drive a fellow mad. The scorpion and centipede, With stinging ants of every breed. Fever and ague with the shakes, Tarantulas and poisonous snakes, Goannas, lizards, cockatoos, Bushrangers, logs and jackeroos; Stunted timber, thirsty plains, Parched-up deserts, scanty rains.

There's barcoo rot and sandy blight And dingoes howling all the night.

There's scentless flowers and stinging trees, There's poisonous grass and Darling peas Which drive the cattle raving mad, Make sheep and horses just as bad. To stay in thee, O Land of Mutton, I would not give a single button, But bid thee now a long farewell, Thou scorching, sunburnt Land of Hell !"

THIs is what the Bushman says in his Farewell, but it must be taken with more than a grain of salt, and we may even suspect that the Bushman did not mean it all himself. I fancy he would not willingly stay 
away for ever from his native land, for those who have lived long there could hardly fail to love their beautiful wild country, in spite of the long list of pests the Bushman has compiled.

And, curiously enough, amongst the pests whose names he has given no mention is made of the very worst of them. I mean the prickly pear, which is perhaps at the present time the most terrible pest the Queenslander has to fear. The very first day I drove through the bush I noticed on many of the trees near the township, soon after we started, a notice setting forth the advantages of using someone's " pear poison," and did not then know what it meant. I found out soon enough. It appears that the Government has offered thousands of acres of good land to anyone who can rid the country of this deadly pest, which, like so many others, has been imported. This one has been said to be due to a girl who brought a small piece of it from America to put in her garden to remind her of her old home. Thence it spread-unnoticed at firstuntil its ravages were found to be getting serious, At the present time about a million and a half acres are lost every year owing to it, and no cure has yet been found. Pear poison acts over the space where it is used, but the plant grows from the most minute eye and will survive a year spent in the air.

One station-owner, who has spent more than $£ 3000$ in trying in vain to clear it from one of his paddocks, told me that he cut a plant of it at the root on one occasion and hung it up on the fence to die. Chancing to pass that way more than a year later, he looked for the plant, and found it growing, and even 


\section{WANDERINGS IN QUEENSLAND BUSH}

flourishing, on the fence, having thrown out a number of its red fruits as if enjoying the situation!

The fruits look pretty-to a stranger; for no Queenslander will allow much beauty to any part of the plant. The yellow flowers are beautiful too; but once the terrible plant has got hold of a piece of ground nothing can live against it, except where it has made its way into bush where the trees are already tall. In such parts one can see the gums standing out from a dense undergrowth of the pear. On the open ground one can watch its progress. First small patches appear in various spots more or less isolated; these grow gradually nearer together, until they have joined, after which they become a dense, matted growth, and if allowed any freedom they grow into tall plants like walls of green spikes, through which nothing can possibly make its way. Pear will grow right down to the water's edge on the seashore, and I have seen it growing between rocks where no other green thing is to be seen.

Emus are said to eat the fruit. It is also said that paper can be made from the fibre of the plant, and a spirit obtained from it, but as yet neither of these can be made in payable quantities, though experiments are even now being carried out with a view to seeing if any use can be made of the pest to compensate in any measure for the loss occasioned by it. In some districts, such as the Roma and Dulacca country, you can ride for hundreds and hundreds of miles through pear without seeing a break in the dense growth, and no one cares to hold any land upon any terms in the true pear country. It is hoped that, as so often happens, Nature will ultimately find a remedy for the pest, but at present 
Man has not been able to do so: the only plan of any use being to burn the plants, roots and all, when they make a certain amount of potash, which is good for the ground; but this does little to atone for the fearful loss. Added to this, the plant is so venomous that it cannot be touched without injury, and I remember only too well getting some of the spines into my hand on one occasion. They were so small that I did not even know they were there, but I suffered from a gathering for several weeks as the result, even after they had been removed, as far as could be ascertained. But it must be confessed that, until it becomes so universal all over a landscape as to become monotonous in its effects, the prickly pear is a most curious and interesting-looking plant.

Another tree alluded to by the Bushman is the nettle, and if a passer-by is stung by one of the leaves he will remember it for the rest of his life, for an English nettle-bed is a pleasant resting-place compared to the Queensland tree. These trees grow to about seventeen or eighteen feet in height, and happily they often grow close together, in or near scrub, so that they can be seen and avoided; but it sometimes happens that one of them will be present among other growths, and one may then brush past it while riding or walking in the bush, when a flap from one of the large leaves will be felt by the sufferer. It is said that horses will die from the effects of severe stinging from these horrible trees.

The next pest after pear in order of gravity to the Queenslander is the rabbit, which is also left out of the list, possibly because it had not yet attained its height. The fact is, that in the hope of keeping the rabbit out of Queensland a wire fence of unequalled 


\section{WANDERINGS IN QUEENSLAND BUSH}

length was built between that state and New South Wales, being placed beneath and above the ground to a good height, for the Australian rabbit has acquired the habit of climbing wire up to a yard or more, in order to escape from an enemy or to obtain fresh grass, and this has to be provided against. But, as might have been foreseen, he has managed to overcome this obstacle and has now begun to spread all over Southern Queensland, multiplying so rapidly that nothing seems able to prevent his becoming the terrible pest he has long been in the southern state. In order to realise the menace of the rabbit it is interesting to study the book lately published on the subject by Mr James Matthams, entitled The Rabbit Pest of Australia. The writer shows that during the past seven years the number of rabbit skins sold in Sydney alone averages $36,000,000$ a year-or 3000 tons of skins; and as all graziers admit that not one rabbit is caught for every hundred that escape, the total rabbit population is estimated at somewhere in the neighbourhood of $3,600,000,000$, and these numbers are increasing in gigantic leaps every year. He calculates that forty rabbits are equal to a sheep in the matter of food, not only because of the actual grass and green food they consume, but because the rabbit is a wasteful feeder, nibbling here and there and fouling the food so that sheep will not eat it, so that the rabbit costs the states about $90,000,000$ sheep; added to which it is a cause for uneasiness that the number of sheep kept throughout Australia is diminishing - " in Queensland alone having dropped in I920 by three-quarters of a million, and that in a favourable year." 
Trapping can do very little in such a state of affairs, and the P.P. Board has long required the farmers to use the poison-cart as the only effectual means of keeping down the rabbits in any comparatively effective way. This cart goes out loaded with sausages made of pollard molasses and phosphorus, which are dropped in all the furrows made by the rabbits, and these are greedily eaten by them. Unfortunately other animals sometimes eat them too, and birds especially suffer greatly, and so do the fruit orchards in consequence, but this seems the only means of even keeping down the numbers. Farmers and others are heavily fined if they let a rabbit loose or, still worse, bring any into a district, a fine of $£$ Ioo being inflicted for a repeated offence; but nothing seems to do any good as far as eradicating the rabbit pest is concerned.

The author says that trapping is about as useful as trying to empty a lagoon with a cup while water is pouring into it, and the worst of it is that the rabbit has taken advantage of any improvements of the land, by clearing, ring-barking and sinking bores, and has in consequence advanced in numbers by leaps and bounds, until now the P.P. Board insists upon every landowner taking certain preventive measures in order to deal with the pest.

Blowflies are another difficulty, and when to these are added the depredations of crows, foxes and dingoes, it is to be feared, as the authorities are beginning to realise, that the sheep-farmer will be driven out of existence.

One more drawback may be mentioned in connection with the presence of the rabbit, in that he is the chief carrier of the disease known as hydatitis 


\section{WANDERINGS IN QÚEENSLAND BUSH}

This is so contagious that no rabbit is allowed into the markets unless it has been examined for the disease, for if anyone eats a rabbit suffering from hydatitis it is more than likely that the disease will be contracted by the human being, and the cure is long and requires several operations. The disease is shown by swellings which contain the hydatitis parasite, and these form again and again.

Rabbits are said to require over two pounds of green food a day, and in a country where grass is so valuable in times of drought this is costly in the extreme to the sheep-farmers, while rabbits get over the effects of drought far faster than domestic animals do; so that altogether the plague is one of the worst from which Australia suffers.

Another pest mentioned by the Bushman is the barcoo, a disease contracted through drinking bad water, want of green food and the plague of flies. It takes the form of scales beginning to peel off the surface of the skin until these can be blown off in clouds, after which sores form. It is most painful, and is only too common in some parts of Queensland.

But to a stranger who has not the anxiety of keeping live-stock alive the worst pests of all are the mosquitoes. It is not necessary to say anything about their doings to anyone who has lived in hot countries, yet no one can forbear to mention these horrible creatures. After a night spent fighting them there is no adjective which seems to express one's opinion of them, and in marching through long grass or scrub or, worst of all, swampy ground, or when sitting down to rest for a few minutes, seeing the hordes of the enemy pursuing 
one, there is a feeling-perhaps peculiar to the stranger-that no pest can equal this one.

But besides the "scanty rains" the Bushman alludes to he very truly adds :

"Here it never rains in reason,

There's droughts one year and floods next season."

And the effects of the sudden floods are often most extraordinary. Every river shows signs of them on its banks. Sometimes it is what were once log bridges lying on the tops of high bushes-or rather what remains of them-or trees and other impedimenta from the neighbouring "cultivations" are lying near the edges or across the river in many places, and the suddenness of the floods can hardly be realised outside Queensland. For instance, a stationowner I met told me that during the late drought, which lasted for three years, he had built thirteen dams to prepare for the rain when it came. Well, it came, and during the first day eight of his dams had burst! And it is no uncommon thing to go out in the morning and before night to find the brook one rode through turned into a mighty torrent. Sometimes the Queenslander-who as a rule can do anything with a horse-drives his animal into the flood and taking hold of its tail manages to get over it. At other times when the flood is impassable there is nothing for it but to seek some rising ground and trust to luck that it will escape the rising water. This refuge will be shared with snakes, rabbits, foxes and innumerable other creatures, such as cockroaches, centipedes and scorpions-refugees like himself from the danger.

One story I heard was of a man who had been 


\section{WANDERINGS IN QUEENSLAND BUSH}

caught by one of these sudden rains while out with a wagon and team of oxen. He decided to outspan and lie beneath the wagon for the night, and selected a hill-side for the purpose, to allow for the drainage. He went peacefully to sleep and never woke again, for when they went out to look for him next day it was found that the ground had become more and more swampy as the night progressed, and he, being asleep, never realised his danger, while the heavy wagon sank deeper and deeper into the mud. After raising the wagon, his body was discovered driven far into the ground by the sinking wagon and this had hardened so that it was not easy to recover the body.

An early settler tells a most amusing story of his escape from a similar flood. He was a sheep-farmer on the plains, and when overtaken by the rising water he managed to get into his house with a friend, but was gradually driven up to the roof by the water, until at last he was forced to take off a part of the roof and sit on the rafters. The two men managed to catch a bag of flour which floated up from the floor of the loft where they were sitting, and finding a box of nails amongst the rafters they tore off some planks and cooked a damper or two on part of the iron of the roof as they happened to have a box of matches with them; this was all the food they could obtain during three days, when the flood subsided and they were able to get out of their prison. The shepherd was found clinging to the branches of a bauhinia-tree which he had climbed, and in which he had lived for the three days off a dead fowl which had floated into the branches of the tree and which he managed to secure and to eat raw. 
A lady relates how on her return from her wedding she and her husband and a friend were overtaken by a similar flood, and how concerned the two men were at the thought that though they could get over by means of the "horsetail" trick she could not, not being used to the ways of the bush, and how they had to camp beside the creek until the water fell. But these sudden floods are often as suddenly followed by sudden " drying-ups," and then animals and birds are caught by the caking mud, which hardens with amazing rapidity in the blazing sun. Wild swans and domestic animals are found caught in this way and it is probable that many of the prehistoric animals whose remains are so often found in the swamps and marshes of bygone ages were overtaken in just the same way as the animals of to-day.

It seems a shame to class cockatoos amongst the " pests," but unfortunately, from a farmer's point of view, this must be done. The beautiful lemoncrested cockatoo exists in such huge flocks that when a number of these birds settle upon a " cultivation" they work great havoc there, from the owner's point of view. But from that of a stranger-especially one who loves birds - it is a beautiful sight to see the cockatoos flying from spike to spike, balancing their glittering white bodies and raising and lowering their crests in the hot sunshine.

The black cockatoos also love grain, though these are not so numerous; and it is interesting to watch a flock of them fly over, for they fly heavily and look like huge black squares against the sky; while the blood-stained cockatoo-another variety -is a curious and interesting bird. The tree which bears their name, the cockatoo tree, with its spikes 


\section{WANDERINGS IN QUEENSLAND BUSH}

of red and white flowers, exactly reproduces the shapes of their beautiful heads, just as the Strelitzia does that of the crested crane, in Africa.

When one sees what a brilliant mark is made by these bright birds, so easily seen by an enemy, it seems strange that while Nature takes care to protect some creatures, by what is called "protective coloration," she has exposed these and other species by their extreme brightness. But the fact is that, except when necessary for their protection, Nature loves bright colours, and until the advent of civilised man with his rifle there was no special need to conceal the cockatoo. In cases where they are not threatened one can see the love of gay colours in wild things. What could be more brilliant than the colours of tropical fishes as they float about amongst the corals of tropical seas? Blue and gold, or blue and silver, they move like flashes in the clear water, which shows every ripple on the sand below them.

And the birds are no exception to the rule. There is no more dazzling object in nature than the trogon of Central America, with his emerald-green body and brilliant crimson breast, with his tail feathers more than a yard long streaming behind him. And the lories of Queensland, and most of the parrots, make no attempt whatever at concealment, screaming noisily as they fly overhead or settle to feed on the trees or corn.

Amongst the lizards, which the Bushman has included in his list, there are not many which do him harm except the goanna, which has acquired such a taste for eggs that it will eat nothing else if it can obtain these, just in the same way as the fox in Queensland will not deign to eat a rabbit if it can get 
a lamb; otherwise the goanna should be looked upon by the farmer as his friend, for he is the enemy of the numerous snakes - which must be given a chapter to themselves, being so important in the category of pests owing to their numbers and deadliness.

An insect pest which has lately entered Queensland, and is becoming serious there, is the grape-vine moth, and the way in which it was introduced is curious. It appears that a number of leaves upon which the eggs of this species were laid were sent from another country to be examined by a Government Department and reported upon. The curator who had charge of them left the room, and as the window was wide open a draught from the open door blew most of the leaves out of the window. When he returned shortly afterwards, and found what had happened, he did all he could to repair the mischief, and had the gardens searched for the missing leaves. Some of these were recovered, but not all, and from this source sprang all the mischief, for the young caterpillars managed to find something to feed upon ; and within a short time the moths have become so numerous that they are now a serious menace to the vineyards of Queensland.

This is only one of the pests which have been introduced into the country-which had enough of her own. Sparrows and starlings have been imported by emigrants and have spread until they are now driving out native species from many of their haunts, especially in and near the towns, while they ravage the small gardens in the suburbs and are threatening the fruit crops in districts where, owing to the quantity of fruit grown, their numbers are increasing at a tremendous rate. The other imported 


\section{WANDERINGS IN QUEENSLAND BUSH}

species, such as the song-thrush and goldfinch, do not altogether atone for the mischief done by the other imported birds.

Amongst plants which have been imported and have become a pest are the lantana, which, brought in as a garden flower, has spread and become a nuisance, " the waste lantana heights," as the poet says, having been covered by the pretty bush so that nothing else can grow there; and the same is said of the water-hyacinth, which has now choked up so many creeks that it is a matter of difficulty for anything to pass through it on the water.

The last serious pest is the ant, and this means all the kinds of ants: white ants, white ants that are not "white" or " ants," red-beef ants, bull-dog ants, tree ants, and green ants, and very many other ants, including hopping ants-they having taken to hopping upon finding themselves in a continent where everything hops. I began to wonder sometimes, when I found hopping fish, whether in time the Australian race would develop habits of walking by hops.

These white ants, or termites, build the most extraordinary nests all over Queensland. Some of them are low, round turrets of red or black mud, being the soil moistened with their own saliva, and sometimes the nests are set on edge like a wedge pointed at the top end; in the north they build castles like candelabra cactus, sometimes building them up to eighteen or twenty feet in height.

Nothing is safe from their ravages. These are the ants which attack buildings, and almost everything else. They are of the family of the Neuroptera, to which belong the dragon-flies and 
ant-lions also, and they fasten down anything they find on the ground, such as boots or books, with a view to eating it later on. A man who lived for years in the north of Australia tells a most amusing story of one such nest. It appears that these termites often begin their nests round something they intend for food, such as an old tree trunk or other object. On one occasion a stockman who was overtaken by darkness lay down to sleep on the ground wrapped in his blanket. When he woke he found he could not move hand or foot, and a terrible fear came over him that he had been buried alive by his companions, who had thought him dead. He kicked and struggled desperately, but could do nothing to free himself, and meanwhile he was getting stifled in the close atmosphere. At last in his desperation he shouted with all his force, and mercifully he was heard by one or two men, who had missed him the night before, on their way home, and had come to look for him. When they found that the sounds proceeded from beneath their feet, as it seemed, they did not know what to make of it, but at last they began to dig away the mound from whence the sounds seemed to come. At last they caught sight of a human boot, and after a little more digging the buried man sat up. At first he thought it was a practical joke, but when he saw that they were as puzzled as himself to account for the accident it dawned upon them all that it was really due to the action of the white ants, who had begun a nest over his supposed remains.

Sometimes these creatures make their way into houses and eat the furniture until there is literally nothing left of it but a coat of paint, and even lead 


\section{WANDERINGS IN QUEENSLAND BUSH}

sheets are destroyed by an acid they secrete which acts as a corrosive, after which they gnaw their way past it for whatever is enclosed inside. Almost every tree is devoured by them, among the few exceptions being the paper-bark ti-tree and the Leichhardt pine, neither of which they touch. Among the cultivated trees liable to attacks by the ravenous creatures are the orange and lemon trees, mangoes and many others, the only ones they do not seem to care much for being the banana and papaw.

Though Queensland houses are built on piles chiefly to avoid the termites, these sometimes manage to surmount this difficulty, unless the piles are cased in iron for a long way up, which appears to act "efficaciously in keeping them out; but though it is this ant which is the most feared, other species are also a great pest in some places, such as scrub, for the terrible bull-dog ants will attack man and domestic animals who may cross their path by accident; while the green ants, which build in trees, will also attack anyone or anything which seems to threaten their homes; so that altogether the Bushman has some cause to include the various kinds of ants in his list of Queensland pests. 



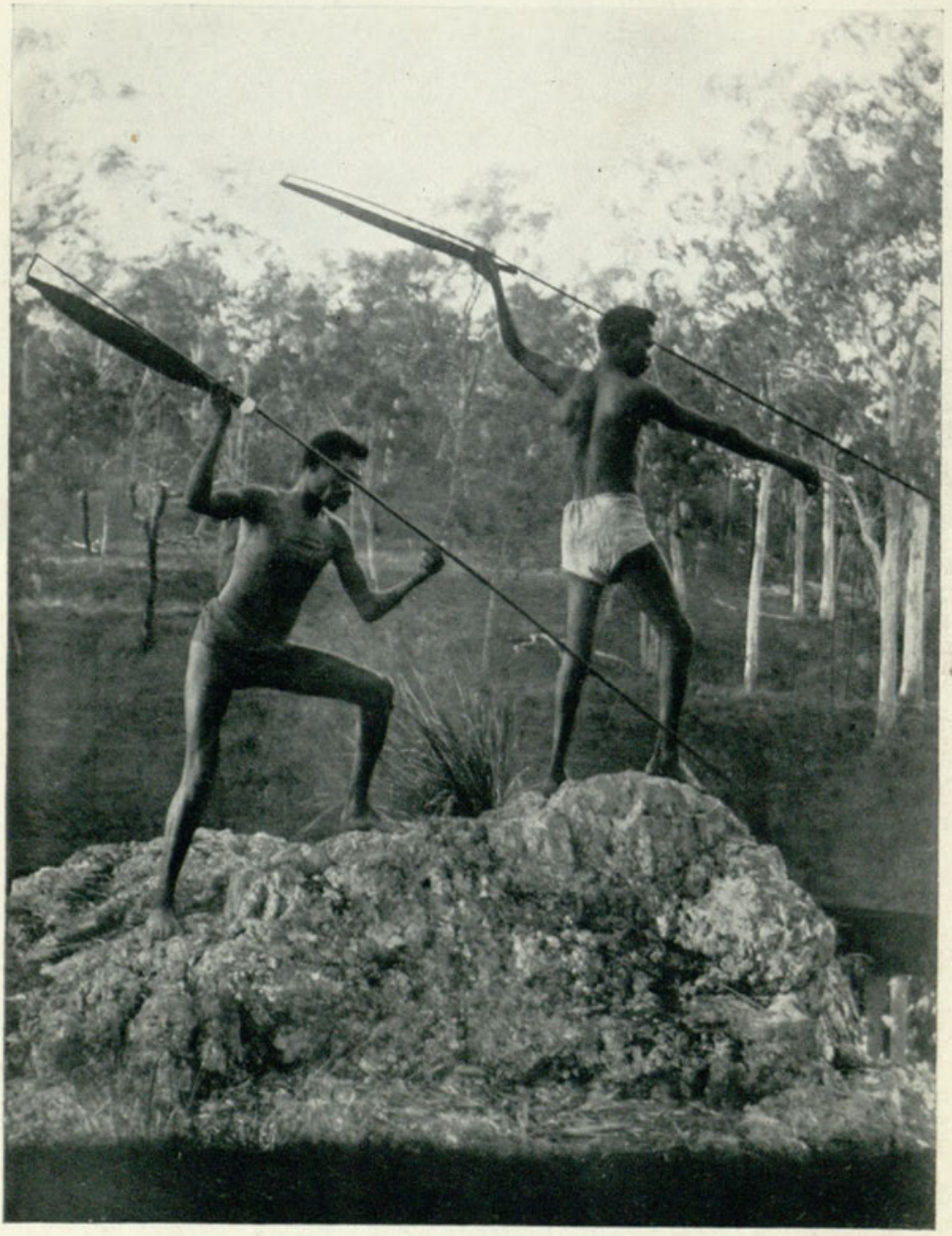

NATIVES FISHING 


\section{CHAPTER VIII}

\section{CONCERNING SNAKES}

A LADY of my acquaintance has a more than common aversion to snakes of all kinds, and yet, when I had the pleasure of her company, more than once, in a museum in Australia, she would always find her way to the snake gallery. Whenever I lost her for a time, while busy elsewhere, I knew well enough where to find her; and I never failed to do so: she would always be found gazing pensively at her old enemies in their bottles; whether with a sense of triumph - over a fallen foe, or, a more generous supposition, perhaps with a feeling of fascination to which she could give rein since they were now powerless to hurt her, I cannot say.

Certainly amongst the "Queensland pests," of which the Bushman gives such a formidable list, snakes should be awarded a prominent place, for their name is legion in that state. Happily very few of these are poisonous kinds-few, that is, in proportion to the number of varieties-or the human race could hardly exist side by side with such neighbours. But there are several kinds which are extremely deadly and must be guarded against. Oddly enough, too, their different poisons act very differently upon the system, not only in speed but in other ways, and indeed snake venom is not sufficiently understood yet in any country where many species exist in large numbers. 


\section{WANDERINGS IN QUEENSLAND BUSH}

This was well shown recently. A celebrated snake charmer in Australia had stood every test as regards the bites of snakes all over that continent, asserting that his antidote rendered him immune from snake poison. I saw him pull venomous snakes out of bags and lay them upon the ground before him, taking care to keep behind them when possible. He then offered to try the effect of the poison upon any bird or animal submitted to him by the onlookers, and declared that he would predict with certainty the length of time which would elapse before the creature died, according to which of the snakes bit it. Personally I did not care to watch the proceedings, but I have been assured that this was several times done, and the man's predictions were verified. He would then allow himself to be bitten by one and would at once administer the antidote; and for a long time this was successful and no harm seemed to result.

But the case was different when "Professor Morrisey," or some such name, undertook a world tour to prove his point and, after visiting various centres, found himself at Durban, where he again offered to allow himself to be bitten by any snake brought to him with its poison fangs intact.

For a few days nothing serious happened, and then a puff-adder was brought and the Professor was bitten. He at once took the antidote, and seemed to recover, though his recovery was not so speedy as in the case of the Australian snakes to which he had been accustomed. Then came a fatal day when a green mamba was brought in. The mamba family are the most dreaded snakes in Africa, for they alone of all the African snake tribes follow human beings 
and strike at them whenever possible, so that in the bush one has to be very careful to see that one does not cross the track of the reptile. In accordance with his habit, as soon as the mamba was let out of his bag he at once struck at the first person he saw, who of course was the Professor. This gentleman did not avoid him, and the snake bit him in three places. He then took the antidote, as usual, but this time it did not act, and within a few hours he had to be conveyed to the hospital. Every means was then tried to prevent collapse, but the unfortunate man died next morning. At the post-mortem it was ascertained that death was, partly at least, due to the bite of the puff-adder, for it was found that the organs showed certain "previous disturbances" to those caused by the bite of the day before death. It would therefore appear that antidotes efficacious in the case of the snakes of one country do not necessarily act in the case of those in another, as the poisons probably contain varying properties according to the species.

Some most interesting correspondence lately took place in the Australian papers regarding the snakes in that continent. One writer suggested that coldblooded animals are not affected by snake poison, and stated that no goanna could die of snake bite. (The "goanna," by the way, is the common monitor lizard of Australia, called (wrongly) an iguana-or goanna in bush language.) Not long afterwards appeared another article stating that goannas feel the effects of a bite exactly as other creatures do, and that in fighting with snakes, which they regard as their natural enemies, they take the greatest care not to be bitten in any vital spot, such as their under 


\section{IOO WANDERINGS IN QUEENSLAND BUSH}

parts. The writer told a story of an experiment in this direction.

It appeared that one day, while sitting round a camp fire with some mates, one of them who had wandered into the bush returned with a tiger snake ( $N$. scutatus) whose back he had broken, but which still lived, and was making vain attempts to reach and strike his enemies who stood round watching him. The conversation turned upon whether goannas ever died from snake bite, and to solve the question the men started off to find one, and as they were plentiful in the bush one was very soon brought in and fastened near the snake, which with his last efforts managed to reach and strike the goanna twice in a vital spot - that is, on his unarmoured belly part. The goanna was then released, and allowed to go where he pleased, but a watch was kept upon him. But the great lizard had apparently lost heart, for he only walked to a neighbouring tree and very slowly climbed into the lowest branch, taking no care to conceal himself, as if he knew all care was in vain. During the following night he fell from the branch, from which he had not stirred, and was found to be quite dead.

Another writer affirmed that a snake which had bitten itself in a rage, having made a wrong move and mistaken its own tail for the stick of the enemy, had died not long afterwards.

Experiments made by careful observers have, however, established that no snake fears its own poison unless when very young, but that almost every other creature suffers more or less from it. In the case of the snake which died after biting itself, it may have been injured by the writer, and died of the injury or from hæmorrhage. Harmless snakes 
are found to die very quickly sometimes from the effects of a bite from a poisonous variety. Thus a rat-snake bitten by a cobra died some hours later, and this result has been repeatedly noticed. Even birds and animals who habitually attack and kill snakes are most careful to avoid being bitten. The mongoose never allows any snake to get within striking distance if he can possibly prevent it. Snakes know this well enough, and always try to escape from a mongoose, which always attacks at sight, but takes care to keep facing the snake and waiting for an opening. In the same way the kookaburras in Australia will fly down from a tree when they see a snake below, seize him by the neck and carry him into the air, dropping him from there and then flying down to attack again, while the snake is stunned by the fall, or possibly has had its back broken. The secretary bird in Africa does exactly the same thing. Our relation the baboon, too, who is extremely afraid of snakes of any sort, will lift stones most carefully before he settles down anywhere, in case a snake may be resting beneath one, and if he finds one will at once try to kill it, if he can, by hurling stones at it from a safe distance.

As regards cold-blooded animals, though death does not take place so speedily as in the case of the warm-blooded ones, three eminent men (Sir L. Brunton, Sir J. Fayrer and Major Rogers), who have made many experiments, have found that frogs in whose bodies snake venom had been injected grew sluggish, and died next day, while if bitten by a poisonous snake a frog will gradually become paralysed and will then die; and that lizards are affected in exactly the same way; the bitten limb 


\section{I02 WANDERINGS IN QUEENSLAND BUSH}

becoming paralysed, and this paralysis soon spreading to the whole body. In the case of the higher animals and man the result takes place more quickly, according to various circumstances. Death is hastened sometimes by such causes as fear, shock or habitual intemperance, though the actual poison may act differently in many cases.

Some bites cause death by means of coagulation of the blood, but all snake poisons do not act in this way, and the symptoms of death vary greatly -sometimes being accompanied by struggling and convulsions, ending in collapse, while in other cases no struggle at all takes place, the victim merely becoming more and more drowsy and sluggish, and finally falling into a deep sleep. I saw a collie which had been bitten and was helped into a quiet spot, where he lay wearily down and went to sleep, never to wake again, and he did not seem to suffer at all; while on another occasion a man was found dead on a melon patch, having apparently been overtaken by sleep, and later on death, while in the act of eating a melon, which he had half finished, and it was not until a careful search had been made at the post-mortem that the cause of death was discovered in the shape of two small punctures found on his body. He had apparently sat down to eat the melon on a heap of leaves and dead grass. Probably if he felt the bite of the snake, which had been resting beneath him when he sat down, he did not recognise that it was anything worse than the bite of one of the bull-dog ants which abound in all such places, and did not even know that death was near, if one might judge from his peaceful appearance. 
When death occurs from asphyxia, due to the coagulation of the blood, convulsions seem to be a common feature, and these come on with greater or less speed according to the variety of snake which has inflicted the wound and the part of the body bitten, the most fatal place being, of course, the body, the next being the foot and the least fatal the hand, which can soonest be reached and treated. Some snakes inject a great deal of poison, such as the terrible copperhead $(D$. superba), a bite from one of which species killed a heifer in three hours, while a death-adder ( $A$. Antarctica) injects still more poison and can kill a dog in three or four hours. The black snake ( $P$. porphyriacus) is another venomous variety, and a rabbit bitten by one of these died within a few minutes. The remaining deadly snake of Queensland, the brown snake (D. texilis), causes death in a more painless way, no struggle being observable and the end coming most peacefully in most cases. Indeed, these deaths are the most difficult to guard against, for many people do not even know they have been bitten in a land where insect bites are so innumerable. For instance, while I was in Queensland a little girl was brought in who had been playing with some others. She appeared drowsy and was thought to be suffering from the heat, but shortly afterwards collapsed and died. When examined the two tiny punctures were found which revealed a snake bite, and the other children when questioned all agreed that they had seen a snake run out from where they had been playing, but had thought no more about it, snakes being a common enough sight in Queensland.

These reptiles often make their way into the 


\section{IO4 WANDERINGS IN QUEENSLAND BUSH}

houses. I remember in a large house where I was staying the lady of the house remarking one evening that she saw the table leg moving in the corner. Of course she had to stand a fire of jokes, but she still persisted, and after a time, to solve the question, the table was approached, when a snake was found coiled round the leg. This was not a venomous kind; but another case was that of a lady who was walking with friends in some bush and who had sat down on a $\log$ to rest. After resuming her walk she complained of a tightness of the leg, and upon examining it she found that a snake had coiled itself round the limb; mercifully this snake-which was of a venomous kind-was killed without having bitten her.

I read while in Queensland one most interesting story of the endurance of snake poison. A man had died suddenly and, though showing traces of poisoning, the cause of death was not ascertained; but later on his son also died, showing the same symptoms. Finally, when the third son was found to be suffering from a poisoned leg, and was lying in hospital, it occurred to the doctor in charge to find out what had caused the wound he found. After a searching inquiry it was discovered that he had worn the leggings which had belonged to his dead father and brother, and when these were scrutinised the poison fang belonging to one of the deadliest of the snakes was found adhering to the leather. This fang had maintained part of its power for a period of several months. And indeed the natives of many countries know this property of the snake poison and tip their arrows with it in order to inflict deadly wounds on their enemies. 
Snakes in parts settled by man are becoming more and more fond of eggs, and a small snake is preserved in a museum in Australia which is cut open to show two large eggs swallowed whole by the creature, for snakes will often swallow objects far too big for them. A case of this sort once occurred in the London Zoo, where the boa ate his mate foot by foot one day, and died a few days later, apparently from indigestion. The carpet snake of Queensland will often eat some large animal. One of them, a serpent about thirteen and a half feet in length, having been killed, a full-grown fox, partly decomposed, was found inside. These huge snakes are said to reach a length of as much as twenty-four feet, but I never saw one more than eighteen feet in length myself. These are not poisonous, but, like the python ( $S$. variegata), they can inflict very painful wounds.

Women in Queensland often set traps for snakes which have entered houses, in the shape of a frog left hopping about or a saucer full of poisoned milk. Both of these are sure draws, the snakes being killed while resting after the meal. I know one lady who showed great presence of mind on the occasion of a snake passing her on its way into the house. She was standing in the doorway when the snake passed her, having seen a saucer of milk just behind her, and as all snakes are very fond of this dainty it continued on its way, whereupon she quickly closed the door when it was half-way through and broke its back. This was a poisonous black snake.

Snakes seem to possess some strange sense of a coming change in the weather, and various movements are observed amongst them just before such 


\section{I06 WANDERINGS IN QUEENSLAND BUSH}

a change takes place. For instance, after a long spell of dry weather, before human beings see any reason to expect a change, snakes are seen to leave their usual hiding-places and seek others. Many of them love to lie amongst the roots and fallen trees near swampy ground, where the rivers have dwindled to pools of water, but before one of the deluges which in Queensland often turn dry water-courses into raging torrents within a few hours they leave the low ground and get into trees. Thus just before the flood which threatened Rockhampton in I9I8, and which had been preceded by a long drought, all the snakes near the town were seen moving away, and very many were found to be resting at the tops of the tallest trees they could find in the vicinity; and this before a drop of rain had fallen, or the change in the weather had been observed. And many other animals were found to have done the same thing, though what instinct had guided them is not known or understood.

I once saw a ringed snake which had been killed shortly after a meal which consisted of a blind snake even larger than itself. Of course it could not swallow the whole at once, but it had begun upon the head and had swallowed about half its victim before it ceased to eat. After this it lay torpid, digesting its meal, and indeed part of the victim was already digested, and the ringed snake would soon have resumed its gigantic meal had it not paid the penalty of its greed, for it was quite unable to move when found.

One more story of a snake concerns one of the most deadly - the before-mentioned $D$. superba. One of these had got into a house which was closely 
surrounded by bush and had curled itself up to rest on the boiler, which was still warm from a recent fire. The owner of the house approached with a stick to kill it as it lay coiled up, but to his horror, finding itself cornered, the copperhead suddenly glided up the stick and made for its enemy, and only just in time did the latter " retreat according to plan," not to return until fully prepared for all emergencies; for though snakes are not usually courageous reptiles " they will fight when they cannot run away," as the famous Major Monsoon said of his Portuguese troops during the Peninsular War.

One naturalist records that he once saw a snake which had been surprised give a sudden dart which betrayed his presence in a tree where he had been lying in wait, but a few minutes later, seeing no further cause for alarm, he resumed his former attitude, which was that of hanging down absolutely rigid, pretending to be a twig, in the hope of a bird or small animal settling upon him, when with a movement like a flash he would turn and devour it.

When injured, snakes will sometimes turn and bite the place, probably feeling annoyed at the pain, but a venomous snake cannot kill himself with his own venom, for this experiment has been tried over and over again. When a snake's poison fangs have been broken off, or in any way damaged, they grow again within a very short time-not more than ten days being required for the process. Snakes often devour each other if a pair are eating the same animal, for their teeth point backwards, so that they cannot relax their grasp, so that if one reaches the head of the other one of them has to begin going down 


\section{IO8 WANDERINGS IN QUEENSLAND BUSH}

the other's throat, and sometimes even the smaller will begin to devour the larger, though he cannot swallow it all at once; sometimes one part of it will be actually digested before the rest has been eaten.

We know very little of the way of the sea-snake as yet - r, as some prefer to call it, the sea-serpentbut young ones are often found on the Queensland coast of a fair size. A story is told of a diver on that coast who found one day to his horror that the lifeline had been snapped with a violent blow. This meant certain death, for he could not be pulled up in time; but his mates afterwards declared that they felt certain this accident was due to the action of a sea-serpent, in whose existence they all firmly believe on the coast of Queensland.

Before a constricting snake-that is, one which kills its prey by constriction and not by biting it-can devour an animal it first crushes it to death and then proceeds to break its bones, so that it can be more easily swallowed. It then straightens itself out and proceeds to swallow the victim, after which it lies in a torpid attitude, resting until the food is digested.

When the horns of a victim are reached by the snake's mouth they stick outwards until the head falls off ; and until this happens the snake cannot free itself or move far.

Snakes in Queensland (young ones in particular) have many enemies, but they now have one less than they used to have; for when the blacks roamed that country in great numbers they were very fond of eating snakes, and were adepts at catching them; even those that are left are often very skilful at doing 


\section{CONCERNING SNAKES}

so at the present time ; but there are few blacks now, and they have found other food easier to obtain and more to their liking: so that that is one enemy removed from the path of the snakes in all parts of Australia. 


\section{CULTIVATIONS}

EVERYTHING is a "cultivation " in Queensland which is an enclosure planted or sown with any crop, unless it is a "paddock" of grass-or so at least it seemed to me, and though I do not love cultivated places as I do the wilds, it is as well to have a look at a few of them. Just now, too, the Government of Queensland is setting aside a large quantity of land in various parts of the state for returned soldiers, so that it is interesting to see what chances there are in various directions for such men to make a living. I am largely taking my figures from the Government pamphlets, to supplement what I saw myself.

I lived on such a settlement for several weeks, where the stock crop was pine-apples, but owing to the numbers planted, in addition to existing supplies, I fear there is not much market for these at present. Then, too, of course, a good deal must be allowed for the great depression existing all over the world during these troubled years, so that almost every crop at present is suffering from a "slump," but it is well to look forward to the coming years in order to see what the chances are when conditions are more normal.

To me the most attractive crop was the vanilla, in a great measure because it does not require clearing away the bush, as vanilla is an orchid, and requires deep shade and moist places, so that the plants can 
be grown upon standing trees, with poles put here and there to keep them from running too far up the supporting trees. These are left as Nature planted them in some parts, though the dense tropical scrub has had to be cleared away. And a vanilla plantation is a pretty sight, with the beautiful flowers and their graceful growths draping the trees, nor does its cultivation involve strenuous work, though the plant is somewhat delicate-and even ladies and children can do a great deal of the work required.

The vanilla seems to have come from Central America in the first place, and was introduced into North Queensland as an experiment many years ago. Here it at once made itself at home, for orchids are natives of Queensland and grow in almost every part of that state. The vanilla plants at once took to running up the trees and had to be trained to run along posts instead, or they would grow too high to reach the pods which are the crop of the vanilla. Added to this, as the humming birds which fertilise the plant in its native forests are absent, they have to be fertilised by hand-this can be done very well by a lady, or even a child, and it is a most interesting task-after which the pods form. When these ripen they are gathered and dried. This work can also be done by a lady, except in the cases where the plant has run too high up. The vanilla flowers are a beautiful pale colour with faint pinkish tints here and there. Oddly enough, neither the flower nor the seed of vanilla give out any scent until the pods are dried, and even then not much until they are crushed.

The rich tropical scrub round Cairns is the headquarters of this industry, which for some years was 


\section{II2 WANDERINGS IN QUEENSLAND BUSH}

practically extinct, an artificial substitute having been found by chemists for vanilla, but now the natural article is preferred and the price is slowly rising, though it will probably never again fetch the prices it did in old days.

Another crop which thrives exceedingly well on the hot, moist coasts of Queensland is the sugar-cane. Here, in places like Cairns and Innisfail, where the mountain ranges behind cause a great deal of rain to fall during the hot season, the steamy atmosphere is exactly what the sugar-cane requires, and it thrives enormously, for it does not need to fear the cold winds and frosts, which it cannot endure. Now and then there are cyclones, such as the two which visited the coast at Mackay and Innisfail in I9I8, and then the damage is enormous, for the canes are twisted and broken and take a long time to recover. But these are happily rare, and meantime the cane flourishes splendidly on the rich alluvial soil on the great river banks, such as the Johnstone and the Herbert rivers, while on the ridges behind are the red volcanic soils which the Queenslanders so prize. Close to the cane-growing lands is the tropical scrub, and some of the plantations are still showing stumps where the forest has been cleared for planting, and the country all round is rich and beautiful in the extreme.

Of course there are pests which attack the cane, and some of these are imported, as the pear was farther south, and the grape-vine moth and many others. The worst perhaps is the nematode, which attacks the roots and causes the tips to club, so that the plant slowly dies of starvation, as the rootlets can no longer draw sustenance from the soil; 



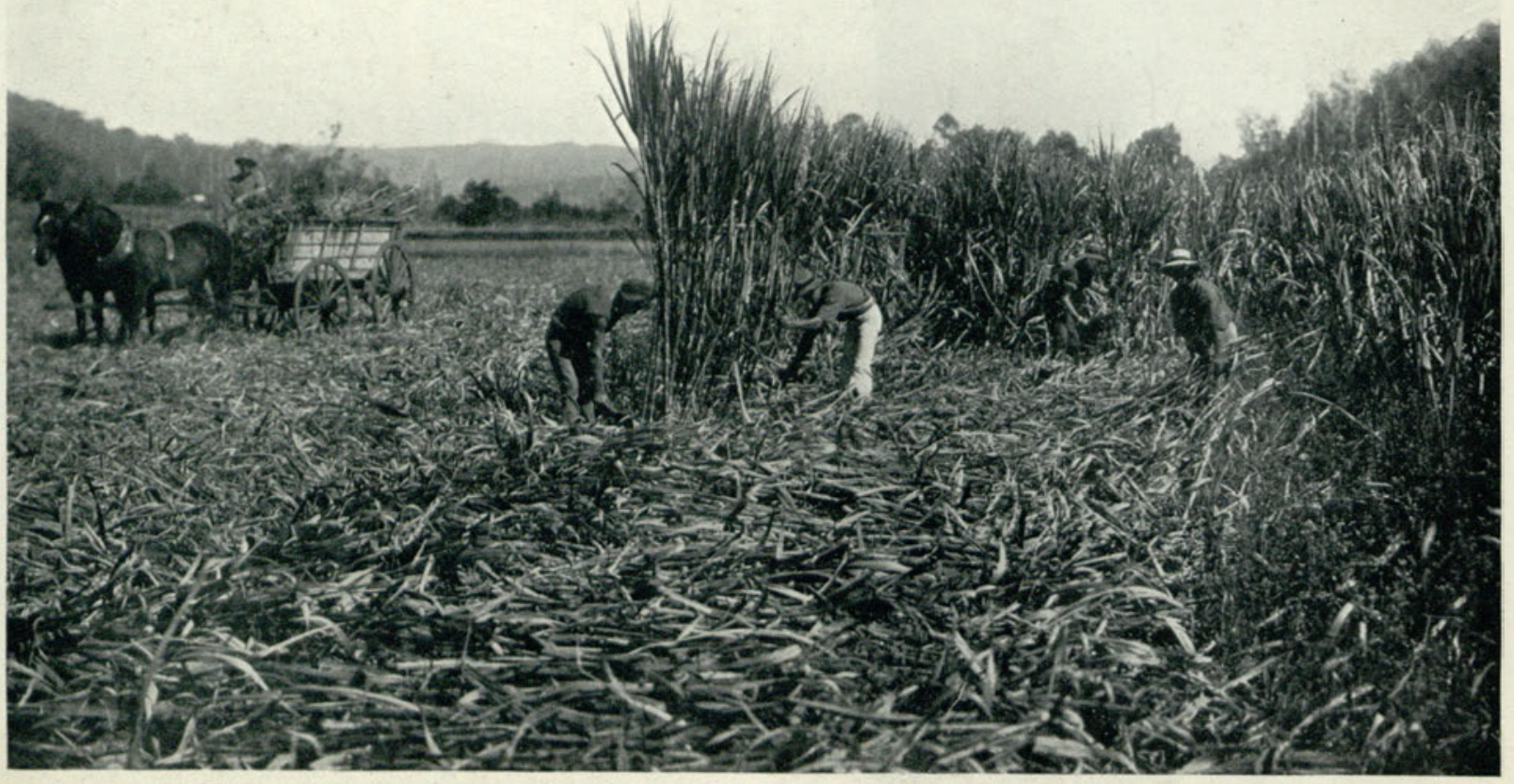


while the beetle-borer also attacks the cane, eating the stem and at last making a cocoon in the heart of it with cane-fibre, after carefully making an opening through which it can emerge later on as a beetle. A parasite fly called the techinid fly was imported from Hawaii to prey upon the borer, but unfortunately the Queensland ants took a liking to the fly and will not let it live there.

Sugar-cane can be grown to within about sixty miles of Brisbane, for the coastal districts of Queensland are all suitable for growing it, owing to the rich soils, as well as the plentiful rainfall during the hottest part of the year; but the density of the scrub makes it expensive to begin such a plantation, and at first at any rate the canes are planted " under stumps," until the ground is cleared by degrees. As sugar is an article which can never be dispensed with, and is required in growing quantities in all parts of the world, there should never be a slump in sugar for long ; but of course, as it requires a high temperature and much moisture, the climate suitable for it must be trying to white men.

Another crop which brings in huge returns - as regards quantity of fruit-is the banana. This is " a gross feeder," and when bananas have been grown for some years on a plot of land it is necessary to put into it a good deal of green manure to replace the good they have taken from the soil. They were formerly grown in North Queensland, chiefly by the Chinese, whose plan was the extremely wasteful one of clearing a rich scrub, planting bananas in the clearing and for five or six years obtaining a huge crop; after this the land was ruined, and they abandoned it for another plot, repeating the process ; this of course 


\section{II4 WANDERINGS IN QUEENSLAND BUSH}

could not go on indefinitely, and nowadays the banana-grower must put back what he has taken from the soil.

Bananas are natives of Queensland and several beautiful plants grow in almost all the hot scrub there. The wild plant, however, does not bear the fruit which can be sold, for it is wanting in flesh, and upon being opened the fruit can be seen to consist inside of a gummy substance " like bird-lime," filled with black seeds clinging to the midrib. No doubt these could be cultivated in the course of years, but there is no need to do so, as we have the splendid varieties which have been so long under cultivation in other parts of the world. It is said that all the cultivated kinds came from the same stock-the Musa Troglodytarum of the Moluccas; while perhaps the very best variety of all-the Cavendish-was brought to Fiji by the celebrated missionary, John Williams, from the Duke of Devonshire's nurseries at Chatsworth, and the lower growth of the Cavendish renders it less liable to injury by the high winds owing to cyclones which rage in those islands.

There are no plants more beautiful than the bananas, and a plantation of them, with their huge leaves flapping in the hot breeze, and their enormous bunches of fruit, is a sight for which to be grateful. I have photographed several such bunches, far higher than a man standing beside them, and Queensland seems pre-eminently suited for the growth, there being a number of native species, with their curious flowers, in every hot scrub in the north. The Government are now setting aside large reserves for returned soldiers, where these can be grown, in addition to which they give expert information and every 
assistance in their power to help such men. At the present time over 3,000,000 bunches of bananas are grown in Queensland per annum, averaging twelve dozen fruits a branch, while some have as many as thirty dozen bananas on a stalk. Except the palms there are no tropical plants or trees I personally think equal to the banana in beauty of growth and foliage.

Another quaint plant -which would be considered a tree in colder lands - is the papaw, which grows all over Queensland, and I think there are few fruits which white people living in the tropics seem to prefer to the papaw, of which they eat enormous quantities. Personally I dislike the papaw, but I am assured that, the taste once acquired, no fruit is preferred to it. I never reached this stage myself, for it always seemed to me to taste like an overripe marrow; but as it is such a favourite there will always no doubt be a splendid market for it. Oddly enough, I found a superstition-for it can be nothing else-very prevalent that it is unwise to plant papaws near a dwelling-house, as they cause depression in the house ; otherwise it is a most popular plant, not only because the fruit is so much loved, but because it is so easy to grow and grows so fast ; so that altogether, in a hot climate, it has many advantages.

The female tree has round fruit, and the seeds from this shape are not so good to plant as the oblong ones which have grown on trees bearing perfect flowers. And here it may be explained that there are three varieties of the papaw-a male, a female and a hermaphrodite bearing the perfect flowers, which are self-pollinated. The male bears fruit, but the size is small, not much bigger than a teacup, and borne on 


\section{II6 WANDERINGS IN QUEENSLAND BUSH}

long stems; the female bears large, round fruit; but the best are the hermaphrodites, which bear large, oblong, yellow fruits of great size. And another odd thing about the papaw was discovered by accident, which is that the sex of the tree can be changed by cutting it to within three feet of the ground, when it will shoot again and bear female fruit a foot below the top. This was found out by cutting some papaws to graft them; the grafts died, but one male tree was left by mistake, and this was found to be bearing a large crop of female fruit.

The papaw grows extremely fast sometimes, as in the case of some trees near Brisbane; these bore a splendid crop just a year after they were planted as seedlings, one of them having one hundred and thirty fruits, and the trees had attained to the height of twelve feet within that time. More fruit still will be borne if the tops are cut off, for they will then branch out, but the fruit is not so large. Another very interesting thing about the papaw is that you can feed the tree by cutting a small hole in the trunk and putting in a small rubber tube connecting the tree with a bottle of sugar and water; the tree will drink the contents greedily and will bear all the better afterwards, or the top can be cut off and the sugar and water can be poured down the hollow stem of the plant. This fruit can be grown with the greatest success all along the Queensland coast from above Townsville to Brisbane.

There are several very valuable uses to which the papaw-trees can be put. The juice has the property of separating the fibres of meat and making it tender, so that it is only necessary to wrap the meat in papaw leaves or hang it on the tree when it will become 
tender. Another valuable property is the juice, to obtain which the fruit is slightly cut and a cup or pan placed below to catch the drops from it. As the juice is corrosive metal must not be used. This is then dried, and a fine granulated product is the result, which is much used in medicine, being very useful as a pepsin-superior to animal varieties. This product always commands a high price, while a decoction of the leaves of the papaw is very useful in cases of fever and the milk from the plant will remove corns and warts; altogether it is one of the most useful of plants, and being very easy to grow pays extremely well.

Another crop which is often planted in Queensland is cotton, for which the climate is very suitable, especially in the north, which is not only warm enough but has a heavy rainfall, which conditions are just what cotton loves. Here it thrives and finds itself at home. Cotton is at present grown in many countries, and as there is an increasing demand for it, it is not likely that the supply will ever exceed the demand. The best cotton in the world is perhaps the sea-cotton of the Southern States of America, and a great deal is grown in Peru, Brazil, India, China and many other parts of the world. All that China can grow is absorbed by Japan, and the Persian crop goes to India, while Egypt sends half hers to England, which also takes a vast quantity from the United States.

In bygone days the Queensland way of planting cotton was to bury great quantities of the seeds in long rows and when they came up to harrow out most of them. Later on the rows were thinned out, and all but three seeds in each clump were removed, 


\section{II8 WANDERINGS IN QUEENSLAND BUSH}

which were left about a yard apart. Later on still, when these were about a foot high, two of the three were taken out and one only left. This plan would not be dreamed of now that the seed itself is so valuable. Nowadays the seed is sold for oil, and this commands a high price, and after the oil has been extracted there remains the oil-cake, which is so much prized for feeding stock; so that no part of the plant is wasted.

Oddly enough, there is a moth which attacks the cotton plants which is a near relative of the silk-worm. It is called the cotton-worm (A. xylina) and lays its eggs on the leaves. Here the little caterpillars feed on the under surface for a time, until they are growing to maturity, when the plant begins to look sickly and the leaves to drop off. The caterpillars then spin cocoons on the plant and hatch out. The female moth is so prolific that if all her offspring reached maturity she would have about 20,000,000,000 descendants in two months. Happily Nature has provided several enemies to prevent such a scourge. One of these is the boll-worm, which is worse still in some respects, for while the cotton-moth only attacks the leaves this pest attacks the young bolls. However they are also enemies of the cotton-worm and eat their chrysalids, and thus prevent too huge an increase of the latter.

These are only two of the creatures which attack cotton, but there is one plan which helps the cottongrower, which is to plant trap crops, as they are called - either of cow-pease or, better still, maize-here and there in the rows of cotton. In this way the moths are attracted to the maize plants, where they will always lay their eggs in preference to laying them 
on cotton if they can find maize plants, and they will therefore appear in huge numbers on the maize plants. This has the added advantage of developing cannibalism amongst them, for, not finding enough of their natural food plants, they will devour each other in great numbers.

Cotton is another pretty crop, for the flowers are beautiful in themselves and the bursting seed-pods, with their masses of soft cotton-wool falling out of them waiting to be picked, are another very pretty sight; and the picking is pleasant work, for there is no stooping about it. This must be done by hand, as no workable machine for picking has yet been patented.

Perhaps the most satisfactory of all the fruit cultures in Queensland is that of the citrus, in all its various forms. I have never tasted better citrus fruits in any part of the world, the next best being perhaps those of Natal. But in Queensland it is possible to get citrus fruits during most of the year, and these are of numberless varieties. For Queensland is the home of citrus fruit, having three native species of her very own - one being a sort of orangelemon called "Citrus Astralis," and there are two varieties of limes, with a pleasant acid taste. These are found chiefly in the north and along the Russell river, in the scrub there, and prove how well adapted this state is for growing the fruits. You can obtain the mandarin, navel, pipless (which was produced by accident by a Mrs Dunning, in the Blackall Ranges, and bears her name), many species of lime, and the shaddock. Most of these will grow and thrive in almost any part of Queensland. The flower of the orange has so sweet a perfume 


\section{I20 WANDERINGS IN QUEENSLAND BUSH}

that this alone makes it an attractive crop to plant.

I think if I were asked my opinion as to what fruit is the most beautiful when seen growing I should decide in favour of the orange. Not only because of its lovely fragrant blossoms, but when the fruit is ripe, and the trees are bending beneath their load, what can be more beautiful than the branches of golden oranges with their glossy green leaves? Lemons are not so attractive; being of so pale a colour they look almost colourless amongst the brilliant oranges, but a large bunch of the latter hanging down is as beautiful a fruit as can be seen -making me for once love a cultivated thing. Indeed I well remember spending one whole afternoon watching the beautiful fruit in a large orchard which had been left pretty well to itself. The owner was a rich man who took no trouble to gather his fruit for the market, and the trees were left to grow as they chose. Perhaps this was why they were so beautiful and bore so well. At least, every tree seemed bending beneath its weight of fruit-shaddocks, mandarins and oranges of many kinds, as well as lemons ; and in the hot sunshine, with the yellow butterflies flying about there, the whole made a lovely picture.

The Queensland Board of Agriculture are very obliging in the matter of assisting those who wish to farm, and seem prepared to give every assistance in their power in the way of expert advice or help. In my own case they most willingly put themselves at my disposal as regards information, photographs, and in every possible way, in order that I might study the conditions of the various crops as freely 
as possible. It is only due to them to say as much.

One great advantage the Queenslander possesses is that he does not have to fear what is so difficult to cope with at home, the frost, which in England has a trick of coming too early or too late and doing such havoc by its unexpectedness. You prepare for sharp frosts in the autumn and winter or springbut then you plant your potatoes or beans only to find that a frost has come later than usual and you see only blackened lines of young shoots. Or your cherished dahlias, which had just begun to look so brilliant in their beds of squares or rounds, starting out of the green grass round them, are " nipped" in a night by a frost which has come too early. Or the east wind will play havoc with the budding trees in an orchard, or a thousand other difficulties have to be met and overcome; and it does infinite credit to the English grower that he has accomplished so much under such trying conditions. Therefore it seems to a visitor that life in a warm climate offers more chances of success, where he can reckon on the climate even in seasons of floods or droughts, if these are not too severe or prolonged.

These are a few of the crops grown in Queensland into whose conditions I inquired. There are others, such as rubber, tobacco, etc., etc. ; but I do not love cultivated places. Perhaps it is because I am so fond of flowers, for instance, that I prefer to see even a "weed" growing naturally to the most beautiful flowers in a garden growing in rows and lines ; but in visiting a country it is well to examine what man has already done there in order to judge both of what has been accomplished and what is 


\section{I22 WANDERINGS IN QUEENSLAND BUSH}

likely to be the future of the country. Judged by an impartial standard-and I tried to be impartial throughout-I should think that when its temporary difficulties are overcome this beautiful land will justify all the hopes built upon her by those whose fortunes are bound up with hers. 


\section{CHAPTER X}

\section{LIFE ON A STATION}

THE very first long day I spent in the bush which surrounded the station where I was staying I counted no less than twenty-three new species of birds -that is, twenty-three I had never seen before in their wild state-and I spent an intensely interesting day watching them. Amongst those I always loved watching were the laughing jackasses, or kookaburras, also called the bushman's clock, and very few settlers will kill or injure a kookaburra if they can help it. I found that there is a variety of this interesting bird in North Queensland bluer in tint than anywhere else, and I never tired of seeing them and watching their ways, though they often laughed at me at awkward moments. It was curious to see them fly down like a flash, dig their stout bills into the ground for some grub, with their tails thrown up jauntily at the same instant, and then fly away, to repeat the movement again and again. I was told of one which had been accidentally killed which was found to contain two pounds of meat, which it had stolen, and which had been set as bait for dingoes, and just before death, with the meat still undigested, it was looking about for more. These birds of course are giant kingfishers. I found another kingfisher, a beautiful azure one ( $A$. azurea), flying about the creek near the station and settling on the ti-trees, with their lovely, red "bottle-brush" flowers, like 


\section{I24 WANDERINGS IN QUEENSLAND BUSH}

a piece of the sky settled there. Yellow and black honey-eaters, with their mottled bodies, were pecking at the flowers, and everywhere were the diamond sparrows, with their coats of grey and red, with red bills for a finish and marbled wings ; these were also feeding on the flowers. Lovely little emu-wrens, with their tails like aigrettes, were flying in the thicker bush, and thickheads or mutton-birds were common also. By the way, it is a pity that there are so many birds with the same popular names: there are several mutton-birds, for instance, and this causes much confusion to a stranger. One of the mutton-birds is a petrel and another is the wattlebird, a bird with a wattle of naked red flesh hanging on the side of the neck, which gives it one of its names. And the apostle birds, with their mournful whistle, flew in their usual numbers-for they have received their name from the fact that they usually fly in flocks of about twelve birds. Crows also gave a mournful cry, like a wailing child, and at first I was alarmed by the call, thinking it really was a child in pain.

It is astonishing what a number of Australian birds are of a grey tint combined with beautifully contrasted colours. One of the most beautiful is the galah, a very common species of grey bird, with a rose-pink breast, and these are most friendly, inquisitive creatures and come quite near, uttering their shrill cry and raising and lowering their pretty crests all the time. To these engaging qualities should be added two others-namely, he is good to eat and easy to catch; indeed a prospector I met who had spent thirty years in the bush by himself told me he had lived chiefly on galahs during the whole of that time. 
Bower-birds are to be found in Queensland, but not so numerously as in the other states. One of the loveliest is the regent-bird, of yellow-orange and black velvet. These birds are most playful, and love a game of hide-and-seek in their bower; and this is also true of the lyre-bird, which is found on the southern border of the state, though more common in New South Wales. A man told me a story of how he had once fallen asleep on a $\log$ in the bush and was awakened by a curious sound, to find that a male lyre-bird was displaying his charms on the open space near him, for the benefit of several plain females. $\mathrm{He}$ was dancing and going through various feats, and suddenly he began a perfect imitation of the human voice and exclaimed: "Come up, Cherry!" " Steady, there, Blossom!"- - evidently imitated from a drover he had heard in the neighbourhood. My friend was so surprised that he laughed and fell off his $\log$, and in an instant the birds had vanished like a dream, but he was certain of the fact. He said that he had often heard the lyre-bird imitate sounds, but had never heard so perfect an imitation before. Happily this wonderful bird still lives and breeds in some quantities in and about the ravines of the Main Ranges and Blue Mountains.

Another bird, more famous for its beautiful nest than its own appearance, is the scrub warbler, which builds a hanging nest, and these nests assume a great variety of shapes; they all contain holes at the side, but some are like cups and some like bags, and some have the hole built out at the side like an afterthought; these birds are still common in the scrub on the southern borders of Australia.

One more lovely bird is the spotted bower-bird, 


\section{I26 WANDERINGS IN QUEENSLAND BUSH}

with its wonderful magenta crest (C. maculata). It makes its bower of the bones of small animals and any bright material found in or near houses, for it will venture there in search of anything brightly coloured. Glass it particularly loves, and bright beads or stones of any kind; but I find it loves the open spaces where it can see all round it, not choosing to build anywhere within the shade of trees.

But birds were not the only things of interest at the station. One day I saw a huge goanna watching me from the foot of an iron-bark tree, and the way it waddled up that tree was a wonder when one noticed its heavy clumsy form. These lizards are carnivorous, being in reality monitors. This was of the species called $V$. varius, while the true iguana is a herbivorous reptile, but in many cases Australian animals and birds are misnamed, and it is difficult to change the names now.

Goannas are common enough-far too common for the farmers, for they have acquired the habit of robbing the hen roosts, for the eggs they so love, and my host's wife at the station told me she had shot several in the act of thieving from the roosts, one goanna having been shot eight times by her before it was killed. She also told me that one was shot there with no less than seven pot eggs inside it, the creature having swallowed these with the other eggs in mistake.

Though so clumsy in appearance the goanna will defend itself well, when necessary, against either a snake or a dog, and it is interesting to watch such a fight, the dog trying in vain to close in on the goanna and get it by the neck, while the goanna on its part will keep cool, but always manages to face its enemy. 
Another curious fight I saw described concerned a praying mantis which had been attacked by a hornet, which had grasped the mantis by its leg while in the attitude as of prayer that the mantis is so fond of assuming. In this case the observer witnessed a most interesting contest. First the hornet, after grasping the leg of the mantis, twisted itself round with the object of stinging the mantis in a vital part, but the mantis on its part closed its leg tightly in order to enclose the hornet and prevent his free movements. The hornet tried again and again to squeeze himself round far enough to bury his sting, but the mantis had him firmly held, and watching his opportunity bit the hornet near the tail, and in so doing bit the sting clean off. The hornet still tried to free himself, though he may have known he was now powerless, but the mantis still held him tightly until he got another opportunity, when he bit the hornet in the head and killed him, after which he resumed his attitude of prayer, like the veriest Pecksniff. When hungry he would eat his late enemy.

One day during my stay at the station I went to see the cattle dipped. This has to be done about every three weeks owing to the ticks. Indeed I saw one heifer with ticks so closely ranged on her back that she looked as if she had a coat of lumps. The dip is a preparation containing arsenic, and the animals usually seem to feel sick afterwards, and indeed it sometimes kills the calves if they swallow some of it; but it is quite necessary to dip them. The stockmen go out and drive in the cattle, and on this station they were aided by the daughter of the house, for some of these girls brought up in Queensland seem able to do anything with a horse. In 


\section{I28 WANDERINGS IN QUEENSLAND BUSH}

this case the saddle slipped while she was trying to head back a steer, but without stopping she grasped her horse by the reins and regained her seat without pausing in her gallop after the animal which was tearing down the opposite hill.

One thing which struck me about these Queensland animals was their extreme docility, for I cannot imagine English cattle-more especially bulls-allowing themselves to be driven into pens and dipped with so little resentment as these showed. About fifty were driven in at a time, and as the cattle on such a station number many thousands it is a work of time, and has to be repeated in several of the paddocks to save trouble in mustering. Even as it is, it sometimes takes the stockmen several days to bring in all the beasts. After dipping, the ticks loosen their hold and within a few days are dead, but if this dipping is not regularly carried out the ticks would very soon increase until they had destroyed the animals.

I heard an amusing story of bush life from my host concerning a show held in an up-country town, but as it has already become known in the state I will not give the name of the town, but will call it " X." It appears that X. had determined to hold an Agricultural Show during the last year of the war, though many people considered it would show a great want of taste-amongst them my host himself, who begged the men of $\mathrm{X}$. to wait for a year, but in vain. The idea was persisted in and my host, who is a leading man in those parts, was asked to contribute, and felt he must do so; but he determined to have his revenge.

It happened that the year before he had obtained a valuable setting of eggs of some kind of fancy fowl. 



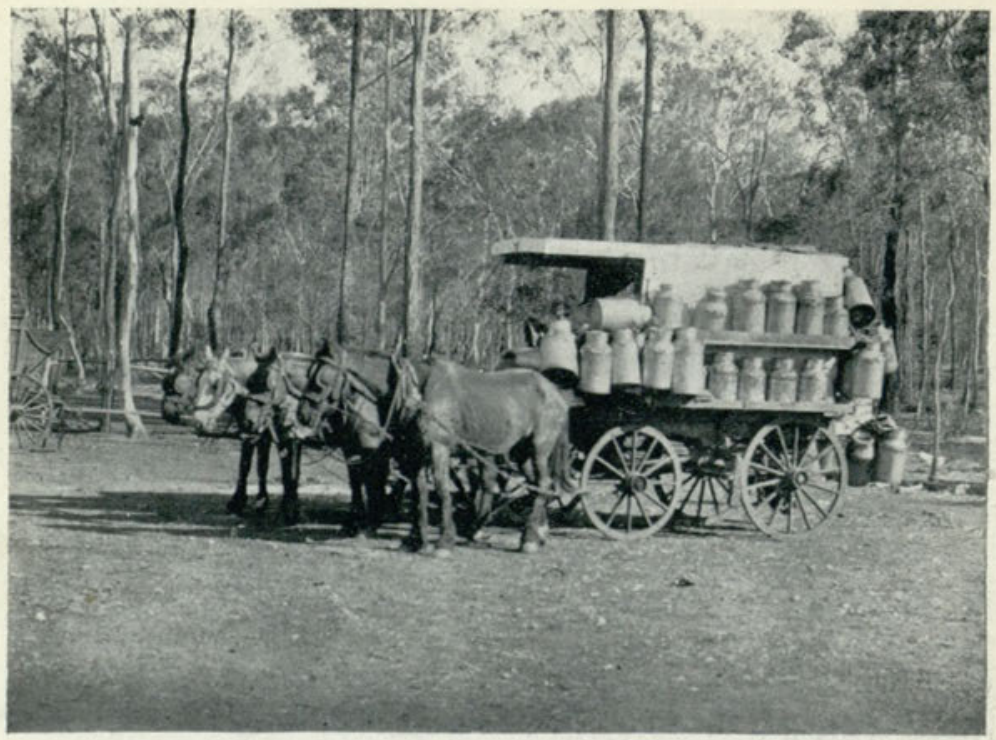

COLLECTING MILK IN THE BUSH

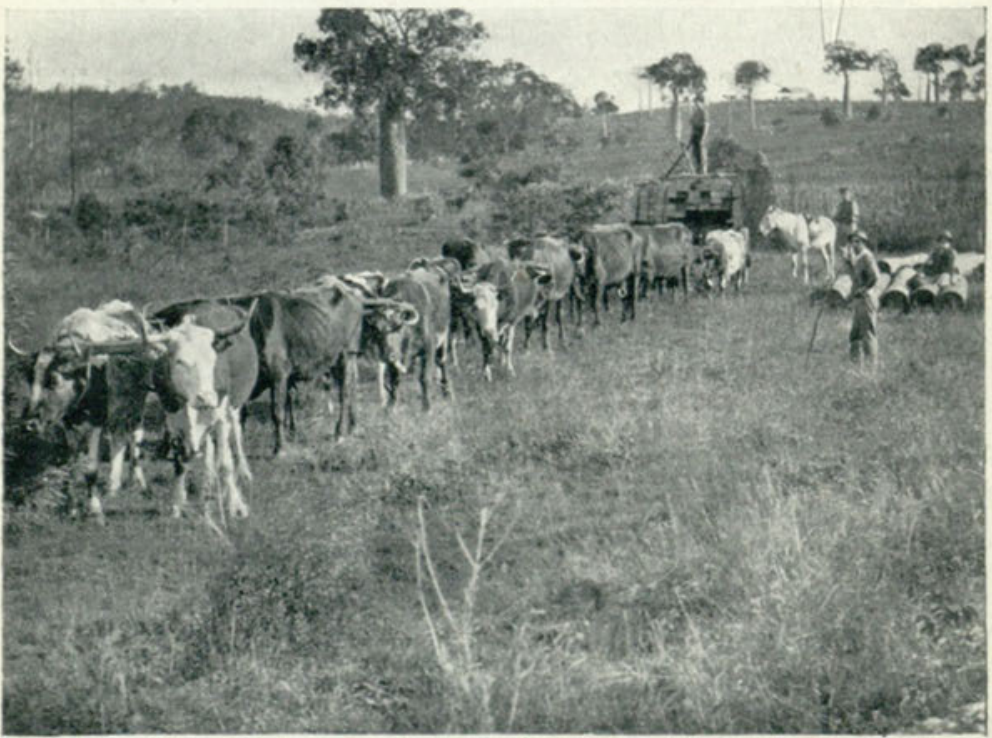


They turned out well, but amongst them was a curious chicken of no known breed. It was thought to be a pullet, but none of the other fowls would associate with it, and it lived and roosted alone in a tree. As it neared maturity it suddenly shot out two long tail-feathers, apparently as an afterthought, and though the whole body drooped toward the ground, like that of a hen during a rainy day in England, the two long tail feathers started upwards with great suddenness and stuck out over the bird's head. $\mathrm{Mr} \mathrm{M}$. therefore entered for the show at X. a new "Floradora" fowl which had just been imported at great expense from the celebrated Belgian breeder's, M. Églai. He afterwards heard that when the entry card was received the committee sent down to the Board of Agriculture at Brisbane to know the points of the new breed in order to have some data to go upon. The authorities at Brisbane knew nothing of the new bird, but this, of course, did not prove that there was no such creature, and accordingly when the show took place the "Floradora" was awarded first prize. Later on when the hoax came out $\mathrm{Mr} \mathrm{M}$. allowed it to be known that he intended to exhibit his famous fowl at every show held at $\mathrm{X}$. in future, and soon after this he received an offer to buy the Floradora. He replied that the price of this beautiful creature-which had now been rendered more valuable by taking a first prize -was six pounds. He duly received the money, and the bird was forwarded and was never heard of again. This anecdote got into the local Press and the name of Floradora is no longer mentioned at X.

I saw during my stay at the station some beautiful examples of the bottle-tree (B. Rupestris). This tree 


\section{I30 WANDERINGS IN QUEENSLAND BUSH}

is carefully saved even when scrub is cut down for the sake of the water it contains and which is used to save stock in dry seasons. It has a great heart of pith which holds a quantity of water and this is as precious as gold in times of drought. Unhappily the bottle-tree or gouty stem does not flourish except in dense bush, so it seems impossible to grow these trees artificially, but they are most quaint and interesting-looking, and one farm in the neighbourhood was named after them as they happened to abound there. Another tree which feeds stock in times of scarcity is the kurrajong, a tree with leaves rather like ivy, and therefore often called ivy-tree by the settlers. The whole tree is more like a poplar in shape. Yet another interesting tree is the brigalow, which seems to grow in circles as a rule, the circles gradually spreading outwards as years pass, for they keep to themselves like some exclusive people. These trees also are saved on cattle stations for the sake of the shelter they give on the hot plains.

I saw a number of ant-lion holes in the dry ground made to catch the numerous ants which abound in -I was going to say infest-Queensland. These are the traps made by the larvæ of a winged fly and they seem to catch a great number of these pests. Of all the countries I ever visited I have never been in one where ants existed in such hordes as they do there. And some of them are dangerous, such as the bull-dog ant, a creature about an inch long, of a dark red colour with bright yellow mandibles. I remember on one occasion at least we had to move our camp because they were found to be all round us. Unlike most ants, this kind does not fly from man, but sits up and faces him; and though one may 
kill a few, there are too many to tackle in hordes. The station-owner told me a story of one of his stockmen who had tied up his dog during the dinnerhour and though he heard it howling he merely thought it wanted to get free and went on with his dinner. But afterwards going to release it he found it dead and covered with the bites of the bull-dog ants which were running all over the carcass. In this case from start to finish he had not been absent an hour.

One day a turkey drive was organised at the station with the object of obtaining turkeys for food. They are plentiful in the dense scrub in that part of Queensland, and the party drove in a sulky or went on horseback to the borders of the scrub country, where the animals were left and the scrub entered. It is not easy to make one's way through this as the bush is very dense and is further tied up with the snake and lawyer vines. Long trails of grey moss hang from the trees and curious snails wander among the dead leaves beneath. Phalangers and opossums abound in the holes of trees, and some of the trunks are absolutely covered with the pupal cases of locusts.

At last the dogs which were sniffing about put up several turkeys and these flew heavily into the trees. Care must be taken with the first shot for one very seldom gets a chance at a second: the only clear mark is the bright yellow ring round the neck of the bush turkey, the purpose of which is difficult to find out as it is the only very distinct thing in the darkness of the bush where they live. Two were secured, and the party went on. One which was shot but not killed flew down not much the worse apparently, 


\section{I32 WANDERINGS IN QUEENSLAND BUSH}

and though the dogs searched long and diligently to find it again it would not move after taking cover and was not found.

There were several of the amazing nests about and these alone were worth going far to see. These turkeys, or megapodes, build gigantic nests like mounds, making them of grass and leaves, which they collect by means of kicking them backwards until they have made a hillock as large as a good-sized room. Not a leaf or blade of grass is to be found anywhere within a distance of at least twenty feet of the nest, which contains many cartloads of material, and in this gigantic mound many turkeys lay their eggs in clutches close to each other, each mother bird, it would seem, keeping to her own part of the mound. Presently the whole heap of green material will begin to heat and the eggs are hatched in a natural incubator. The young turkeys are quite able to look after themselves from birth. As soon as they are born they peer cautiously out of the mound and then run off into the bush, where they begin scratching for worms and grubs at once. These turkeys are now protected, and they are still happily common in many parts and are much prized for food as they are very delicate in flavour ; indeed I have never tasted a better game bird. It reminds me of glorified guinea-fowl.

Lovely orchids grew in the turkey scrub and a beautiful white trailing flower - a species of Capparis -and a pale purple flower on a bush of the sarsaparilla family; and in open spaces grew bushes of what the settlers call " shield-tree," from which the natives make their shields, and which has masses of delicate pointed flowers of greenish white. 
Thousands of cockatoos flew overhead. I saw one dead tallow-wood tree literally covered with the white cockatoos with lemon crests which are "noxious pests " in Queensland and another beautiful cockatoo, called " gang-gang," of grey and red with a brilliant crimson crest. But indeed I could not tell a quarter of the birds I noticed in these scrubs.

A great number of the trees were inhabited by swarms of bees. I was puzzled at first to find that they were of the same species as our English bees, until I heard that numbers of these had "gone wild" and taken to the bush and had prospered there exceedingly, like so many introduced species. One day I spent with a settler taking some of these bees. $\mathrm{He}$ made hives in his spare evenings, and having got several ready and marked the trees, he and a companion would cut down the trees one after the other -no long matter for these hardy men-and would then take the honey and put the bees with a little of their own honey into the hive on the ground. Sometimes they would try to swarm again, but this he tried to prevent, as it was then necessary to cut down another tree as a rule, and this wasted his time; but I saw him hive three swarms in a day successfully, and he then left them till the evening, when he moved them to his farm. In this way he is gradually building up a large business, for he sells honey to shops in the towns which has cost him almost nothing in the first instance. I may mention that during the day I spent with him he obtained two large pails full of rich honey excellent in flavour though slightly " woody," but perfectly clear.

I saw some lovely butterflies while at the station, though Australia is not so rich in butterflies as Africa 


\section{I34 WANDERINGS IN QUEENSLAND BUSH}

or America. But they have the beautiful green and black Troides with its bright gold body, and the Attacus moth seems native there, and many of the swallow-tail family are natives there also. Curious grasshoppers like green thorns abound and crickets of many kinds.

One day while in Queensland I watched a long train of caterpillars on the march. They were going steadily along one after the other, head to tail, on and on. I followed the line of them and found that in their wanderings they had reached a tiny stream, and here a chain of them had got across and had made a living bridge, and upon this bridge the rest walked over one after the other too. I was told by a resident that when the last of the caterpillars on the far bank had passed the living chain lets go its hold on this bank and swings down-stream with the current, after which they climb one after the other over the remainder of the bridge until all have landed. It seems some strange instinct which guides them. In the case of the one I watched I could not find the end of the line though I walked a very long way beside it, and at last I lost it in some thick bush.

We went for many interesting drives across country while I was at the station, for the daughter of the house had a small Ford car of her own which she could take anywhere, I believe, and drive anywhere - except possibly up the side of the house. Bush did not frighten this demon driver, for she could always manage trees by getting round or under or over them, and when I say across country I mean a sort of steeplechase, for we never even pretended to keep to the tracks. Once we stayed for the night at a primitive "hotel " called the "Ritz" or "Cecil," 
I forget which-its name proved to be the only resemblance it possessed to the original-but in a new country trifles do not matter, and every day brought its own pleasures.

One drive in particular I remember. We had been to the " bush store," a sort of " co-operative stores," at a crossroad, and had then left even the pretence of a road. Presently the car gave a leap rather more wonderful than usual and I was thrown violently against the roof. When I regained my seat I found we had crossed a small river by means of a few logs lying about anyhow which had once pretended to be a log bridge and that we were now stuck in the marsh beyond. There was nothing to be done but to wade ashore and go across country for help. We wandered in various directions till I chanced to come across a man looking for some of his horses which had strayed, as they always do when not actually at work, in search of food for themselves. He promised to come when he had caught a couple, and I could see him in the distance riding after some apparently wild animals with a rope; but somehow he managed to secure a couple and returned, whereupon, as usual, the rope was fixed to the back of the car and we were pulled out backwards. After this we resumed our journey. But I believe that if fortune had not favoured us and we had had to pass the night in the car it would not have troubled my valiant driver.

We camped for our tea that evening beside a lovely river. The water was low -as rivers are in Queensland when they are not too high, owing to cyclones or some other disturbance - and we walked up the side for a long way. There were sand-banks along the river and these were covered with the 


\section{I36 WANDERINGS IN QUEENSLAND BUSH}

footsteps of kangaroos which had been drinking there recently, for these animals abound there, and the red ti-trees were a beautiful sight all the way up the river banks. There were high banks of maidenhair fern and wild violets with pointed leaves $(V$. hederacea $)$, and the bushes were covered with the beautiful red pea (K. rubicunda), which threw its trails all over them. There are few prettier flowers in Queensland, unless it be the true desert pea with its red wingpetals and black and white centre. Two other flowers I love greatly, but these are not natives of Queensland unfortunately, are the flannel flower (A. helianthi) and the waratah; but though these grow so freely in the neighbouring state it seems they will not thrive in Queensland. There are numberless flowers, on the other hand, peculiar to the latter, so it would appear that there is some subtle difference which only the flowers know in soil or climate.

And along my river the kingfishers and honeyeaters were flitting amongst the flowers; and I do not believe I ever saw a lovelier river in Queensland than this one, so far from the beaten track that it only possesses a few rough log bridges thrown over it, which renders it all the more lovely in my eyes. We boiled our billy beside it as the evening was drawing on, while the sun was setting behind the silver stems of the gums, and I do not ever remember a meal I enjoyed more than that one taken in the lovely loneliness of the bush. 



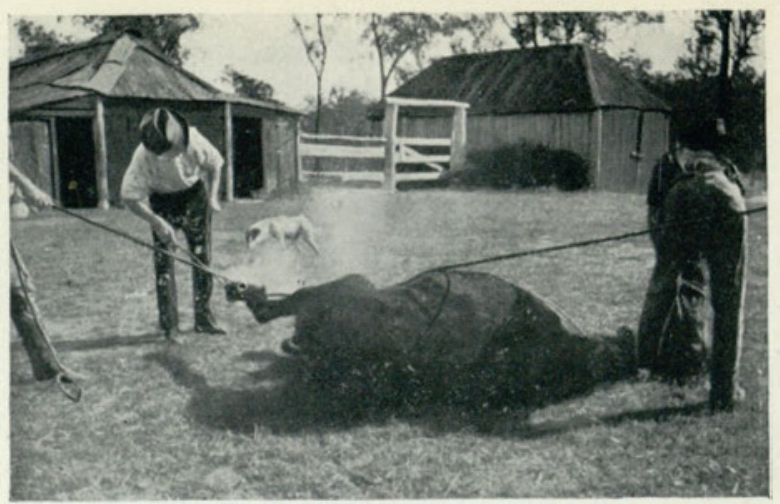

SHOEING A BRUMBIE

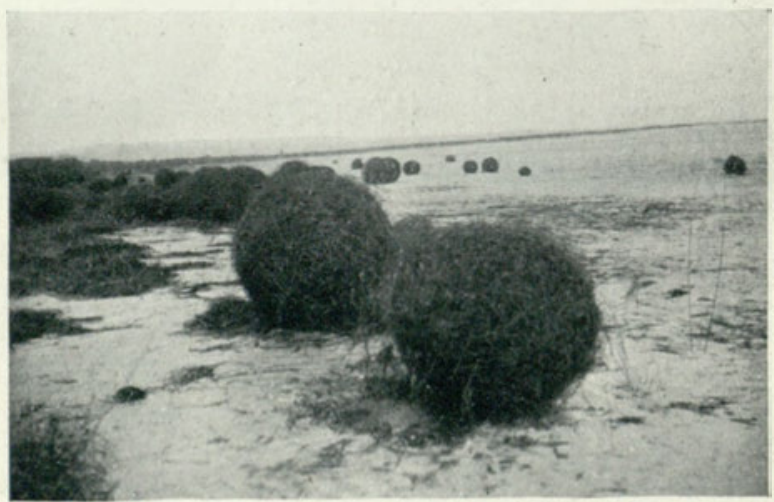

SEA-GRASS BALLS

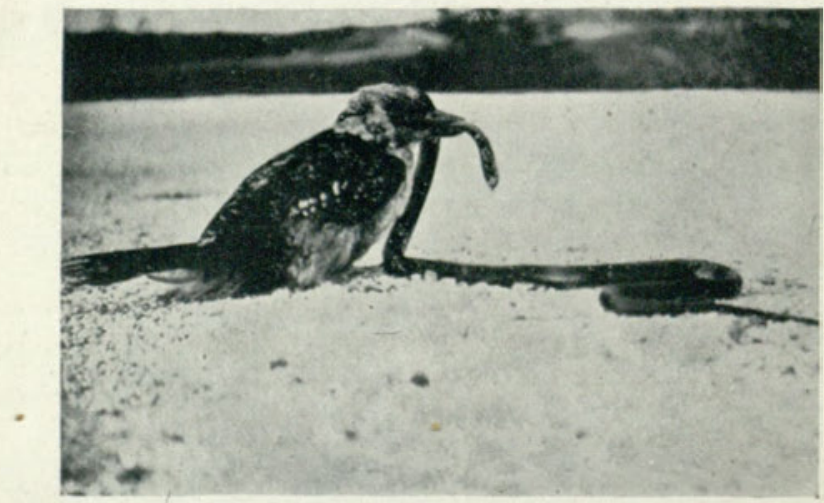

KOOKABURRA AND SNAKE 


\section{CHAPTER XI \\ SOME CURIOSITIES}

IN a most interesting book the naturalist $\mathrm{Mr}$ Le Sou ef mentions having found several small sea-snakes on the Queensland coast about fifteen feet in length. $\mathrm{He}$ adds that he firmly believes in the existence of the sea-serpent and tells two very interesting stories in connection with the monster.

One of these is the tale related by a Captain Worsley of the cable ship Sherard Osborn, who showed the author one day a curious piece of snake-skin of an unknown kind which had been brought up when the cable was lifted and examined, and which had been found adhering to it, probably because the seasnake had sloughed his skin by rubbing it against the cable. This piece-whose edges did not coincide -was part of a creature bigger than is at present known to inhabit the sea. The captain had preserved the piece of skin in a glass bottle. The second story is that of another captain who told the author that about half-way between the Cape and Australia he had suddenly seen a monster of which about thirty feet were out of the water, while he saw quite as much as thirty feet in the sea before it dived. It had been advancing "in a shooting manner" until alarmed. Added to this, on two occasions ships have reported seeing young whales struggling to free themselves from some kind of snake which had coiled itself round them. 


\section{I38 WANDERINGS IN QUEENSLAND BUSH}

I remember a story of much the same kind. Upon one occasion I was on the bridge of a ship speaking to the captain, who was a most reserved, quiet man as a rule, and suddenly spoke of the "legend " of the sea-serpent. He did not answer, so I asked him if it was possible that he believed in such a monster. $\mathrm{He}$ answered quite calmly that he not only believed in it but had seen one himself, but added that he never mentioned it, knowing he would not be believed. When pressed he mentioned the same place as the last captain had done-i.e. half-way between Africa and Australia - and repeated exactly the same thing. However this may be, it is certain that a large seasnake exists and can be seen along the tropical shores of North Queensland.

Perhaps the most wonderful of all the survivals of the past in Queensland is the lung-fish or Ceratodus, which is still found, though in diminishing numbers, in two rivers in Queensland-i.e. the Burnett and Mary rivers. This quaint fish has not only " uncanny lungs," but ribs also, and is annually caught for a fish dinner held at Gayndah, when this is the principal dish of the evening. The flesh is rather like coarse salmon. The whole fish is about twelve pounds in weight when full-grown, and it is an odd fact that no young ones are ever found, so that their habits are little understood at present. This most interesting fish was once a common type, but has been extinct in most of the world for many ages, being of the Jurassic period and contemporary with the Ichthyosaurus and the Plesiosaurus. At present it has very few relations left on earth, the only ones who also possess lungs at the present time being the very rare $L$. annectans of South America, which in 
dry weather buries itself in mud and can survive for a long period owing to its lungs, and a similar fish in Africa with the same powers.

In the case of the Ceratodus the creature possesses long slender pectoral fins which would in the course of coming ages probably have developed into arms and the creature would have become amphibian, but now it is likely to become extinct, for its haunts are only too well known, and it is retreating before the white man ; otherwise it would have been most interesting for those in coming ages to watch the slow evolution of the Ceratodus just as forms have evolved in the far past of the earth. It is an interesting fact, too, that long before English or Australian scientists had taken much notice of this weird creature the German scientists were greatly interested in it, and specimens were sent to the Kaiser long before the late war, as he had heard of it and asked that some should be forwarded to him at Berlin.

Another curiosity of Queensland, though happily not a rare one as yet, is the frilled lizard (C. Kingii), the "dragon" of old writers. This curious-looking creature is often seen walking about on its hind legs, for it does not crawl as other lizards do, but stands erect, and is often more than a yard high. When it is frightened or annoyed it raises the huge frill round its head until the whole of its body is concealed by it, and shows all its teeth in a terrible scowl intended to alarm its enemies, much in the same way as a lion does. But when caught the poor frilled lizard proves to be a most harmless, helpless creature, and can be handled without the slightest fear, for it has no weapons of defence at all beyond its alarming appearance. 


\section{I40 WANDERINGS IN QUEENSLAND BUSH}

Another curiosity in Queensland is the water-frog, a creature which, like the one in the fable, has the power of inflating itself enormously - but with water only. When the dry weather comes, and the pools and rivers are drying fast, the water-frog will drink a vast quantity of water-for his size-and then bury himself in the fast-caking mud, and in that spot he will sleep; gradually absorbing the water he contains during the long months of drought. So well was this habit of his known to the blacks who wandered in those solitary deserts that they used to dig up the ground round the dried water-holes and lakes and upon finding the frog would drag him out and drink him.

Quite lately a descendant, or at least a distant relative, has been found of the long extinct Trilobite. This is the Apus, which has lately been discovered in one of the pools in the "Dead Heart of Australia," which with a few shallow lakes represent all that is now left of what was once a vast inland sea. The Apus is locally called a "tadpole" or a "water-dog" by the few residents of those districts, but he is in reality a most interesting creature, being a representative of a decayed family of the past.

Just as the marsupials still carry their young in pouches $-a$ habit which has proved fatal to them in other continents, where the fight with the betterequipped placentals proved their ruin-so the habit of the fish of the Queensland coasts, which carries its eggs in its mouth to save them from destruction, is a habit which must prevent the mother fish from feeding as she should, and will in time prove her ruin too. The same must be said of the two monotreme -or egg-laying mammals-which still maintain a 
precarious existence in this continent so remote from other lands. It will be a sad pity when that day comes and these two curious and most interesting animals have vanished from their last haunts.

And there are plants, too, which linger here whose family " has seen better days," amongst them the horsetails or Equisetums, which once held an honoured place amongst the plant families until driven out by newer forms more capable of maintaining the fight with other species. These I found growing in very many places in Queensland, and sometimes they attained a very respectable height, as horsetails go at present, though they would not be recognised by their relations at the height of their glory in the days when the coal measures were being laid down. The cycads are also aristocrats, and hold their own bravely against the tree-ferns in many places. When the tract of country where cycads grow thickly is burnt by a bush-fire one can see the tall stems standing out like so many straight black posts, with the crown of foliage above looking rather like treeferns, but with coarser, less lacy foliage than the graceful tree-ferns, amongst which they live and struggle:

Another curiosity is the stick caterpillar, which I often saw walking about during my rambles. This creature, whose mother laid him as an egg upon a gum-tree, soon leaves the tree and wanders about at its foot collecting a number of small twigs in which to encase himself, so as to protect himself against his enemies, and he looks rather like a walking pin-cushion when moving about. Even when he eats he only puts his head a very little way out, and upon the slightest sign of danger it disappears into his 


\section{I42 WANDERINGS IN QUEENSLAND BUSH}

curious dwelling, and the whole looks like a tuft of rubbish which has got together accidentally. When he turns into a chrysalis he still retains his dwelling, and lies warm and snug inside his stick cocoon, which he has hung to a twig of the gum-tree and of which he has sealed the ends, and here he lies until the time comes for him to emerge.

A bird which builds a somewhat similar nest on a large scale is the gerygone or floodbird. She attaches her floating nest to a reed or two and lets it float on the current. She builds it more than two feet long in some cases, and it looks to any casual eye like a huge heap of rubbish accumulated by the flowing water and held together as if by accident. But in the loose mass she has made a soft nest at one end, and in this she lays her eggs and hatches her young ones undisturbed.

The megapodes or mound-builders, who lay their eggs in a huge mound, drag together enough material to fill a room; but it is the male bird who builds the mound, and he appears to take the greatest interest in his work. He resents the hen coming anywhere near the home he has prepared-or rather he and his mates have prepared, for several work at it-and it is with the greatest difficulty that the females can approach to lay their eggs in the huge heap. The hen bird is just allowed to come to the hillock and scrape a small hole, wherein she deposits an egg, but the jealous male, who is watching her, forces her to leave it as soon as she possibly can, when he fills up the little hole she has made for her egg at once with the greatest care, evidently thinking she is not safe anywhere near the home he is building with such loving interest. 
A vegetable curiosity of Queensland is the parasitic fig-tree, which throws a root towards the fork of a tree upon which it desires to fix itself and catches hold of it in this way. It then inserts a tiny rootlet into the hole and winds itself round the tree, gradually throwing down tendrils towards the ground. As the strangle-hold gets tighter the tree begins to die, for there is only one end to the contest, and as the wood gets rotten the fig fills it with roots, until it takes the actual shape of the host-tree at last, and when the tree is dead the heart is found to be full of the roots of the fig.

Another parasite is the bean-tree, with its pods more than two feet long. These contain the round Queensland beans which are used to make various pretty fancy goods and are a bright brown in colour. Brilliant cockatoos flutter round this creeper for the sake of the beans, which they eat.

Very interesting creatures are to be found on the shores of Queensland too. I have one coral about the size of a soup-plate which has taken the trouble to reproduce exactly the horse mushroom of an English meadow. There are the flat top, the gills made of stone, exactly as in the original, and a long foot of coral also. One wonders what was Nature's object in growing such a form in the shallow waters of the coral seas. Perhaps, as in the case of the eye on the peacock's tail, it would seem as if she were proud of the design and had reproduced it several times in different creatures, just as the peacock's eye is reproduced on a beautiful butterfly, a bright bird and a curious little fish. At any rate one might easily mistake this coral at a small distance for a large mushroom. 


\section{I44 WANDERINGS IN QUEENSLAND BUSH}

Amongst the strange shells on that shore are some that excite wonder also. What can be the object of the giant clam in growing a shell so frightfully heavy that in some cases it takes two men to carry it for a few yards with great difficulty ? It would seem hard to imagine how such a backboneless creature as the one for whose benefit it was designed could lift or move such a weighty object. And other shells on the same coast are equally curious. There is one which resembles a limpet, but when removed from its rock it is seen to consist of shell, only leaving the tiniest aperture for the fish which lives inside. This is true too of the beautiful mitre shells of Queensland. It is difficult to conceive how anything small enough to get into that tiny hole could move such a shell. A lovely little spiral shell found in the warm waters of the Gulf, which looks as if it had been exquisitely carved out of ivory, has a hole so tiny that it would seem as if nothing could possibly squeeze into it, yet it has a long tail stretching out below it !

Another very curious object of the ocean often brought to the surface by divers in those seas is a plant with black shining stalks and branchlets. When this is softened in water it can be made to assume any shape desired, but it has no leavesor rudiments of any - and nothing is known of its growth. And one more curiosity of those shores is the vast amount of the sea-grass which is brought in by the waves. Some banks are made of nothing else, which the sea amuses itself in some bays by rolling into balls and oblong shapes and then throws farther up, so that every tide leaves them higher up. In some bays nothing else but this grass is to be seen, 
though one wonders why Nature made so much of it and then wasted it, as she does so many things.

When one thinks of the numberless odd animals and plants which have survived down to the present in Queensland, and indeed all over Australia, one wonders at the means Nature has sometimes taken of arriving at her object. As a Queensland naturalist - Mr Heber Longman-has well remarked of the apparently useless contrivances devised by Nature, it is as if she were groping and experimenting in every direction before she decides upon any final form. Thus the tree-ferns throw hundreds of millions of spores of which how few survive! And a fish will produce thousands of eggs for every one of her offspring which can grow to maturity. The huge extinct monsters of the past were burdened with masses of bony plates far in excess of what was required for safety, and which would alone have ensured their destruction, since they could not drag about such cumbrous weights for many generations, especially when newer, swifter forms were appearing upon the scene. The toucan has a bill so clumsy that he can hardly manage it now, and the extinct elk had horns so monstrous that he could hardly have got through thin bush country.

$\mathrm{Mr}$ Longman mentions also the case of various orchids which are so specialised that they can hardly be fertilised, and a whale which has two teeth which grow to such a size and into such a curve as gradually to close its mouth and prevent it from eating. In the same way the sabre-toothed tiger, which began by using a long tooth, found it in time growing to a length which prevented its owner from eating, and this also ensured its destruction. In this way also 


\section{I46 WANDERINGS IN QUEENSLAND BUSH}

the marsupials, who have to carry their young with them, could not compete with an animal which leaves its young at home and goes to them with food when all is safe. And a mammal like the dugong, which has to feed its young in the water while having to bring it to the surface to breathe, has a double task to fulfil to meet the dangers of land and water. This is true also of the poor platypus. And the spiny ant-eater, though she does not live in water, has to carry her young one about as well as having to hatch it in the first place as she walks. Only in an isolated portion of the earth could such creatures have survived down to the present time.

But at last it would seem as if an effort were being made to save them from extinction, if it be possibleeven at the last moment in some cases. A park has now been set aside, in the form of a large national reserve at Lamington, and in this sanctuary it is much to be hoped that the last poor remnants of some of the Australian fauna will find a resting-place where they can live out their simple primitive lives in peace. 


\section{CHAPTER XII}

\section{THE STONE MEN}

UNLESS one is prepared to go far afield now it is difficult to see the Stone Men at home-that is, living as they always lived until the white men came. Most of them are "rounded up" now, and placed in reserves, and those in charge of some of these at least do all they can to help the poor doomed race to die out in peace. Of course the treatment of the blacks varies in each case according to who is in command of the reserve, but it is an attempt at least, though a belated one, to do the State's duty to those whom it has dispossessed.

When these aboriginals are left at liberty near a white settlement the effect is disastrous, for tobacco and spirits drive them absolutely mad, and then very often the worst occurs; but in some regions still left in the vast interior, and in the north and west, the natives still roam about much as their nomadic ancestors did. Some of the tribes are fine-looking men, such as those on the Queensland coast, where the food is plentiful, but in the waste land in the interior, in what Professor Gregory calls the "Dead Heart of Australia," they are a stunted race, the men sometimes being not more than five feet in height and the women less still. Very often in bygone days these blacks helped and aided the white men who had fallen into their hands, until they had learned by bitter experience to fear the white man and his 


\section{I48 WANDERINGS IN QUEENSLAND BUSH}

rifle. The quarrel between the two races is easy to understand. No native tribe ever allowed any other tribe to come into its territory and rob it of its scanty store of food, and if this was done reprisals took place. If some of the Mulga tribe entered the land of the Darling river blacks and speared or snared their kangaroos, the latter returned the compliment by killing and eating the emus or other game of the Mulgas. But when the white men came into the territory of both, and shot and killed their precious food supply, the blacks naturally enough - not understanding the white man's logic-speared his cattle. This being an unforgivable offence in the cattleowner's eyes, he shot the "cattle thieves" at sight, and the black men speared the whites when they got the chance; but when a fight occurs between a man with a boomerang and spear and another with a rifle there can be no end to the quarrel but one, and in this case the victor got off very lightly in the matter of killing the poor Stone Men.

A very great injustice has been done to these in considering them incapable of being taught. At any rate I was told by the heads of several of the reserves that some of them are most intelligent, and can be easily trained in certain subjects for which they have an aptitude - though in the case of some tribes at least they are easily led astray if they wander away for long from the settlement, which they can sometimes get permission to do if they get employment elsewhere-and certainly I saw one mission station, where the A. A. Mission is at work, where the results are most encouraging. I was given a photograph of two girls, taken on their wedding morning, with their long silky hair smoothly brushed (and their hair is 
the chief beauty of all the full-blooded natives), and the contrast between them and their wild relations was very striking. The lady in charge also told me that she had always had one at least in her house, and had never lost a single thing, and that they served her with the most touching fidelity. And those men who have contracted alliances with black gins on the outskirts of civilisation have always found that they make perfect slaves, being almost like dogs in their love for the men with whom they come in contact. Unfortunately it is in their treatment of the gins or lubras that the aboriginals are at their worst, for they treat them like so many chattels. The women do all the work, such as digging the ground for roots with the clumsy tool they call "kirtree" or yam-stick. These are blunt clubs, and the poor lubras have to dig up the hard earth with this one implement. They have to carry heavy loads such as kangaroo meat and any household goods they possess, in addition to their babies, and in spite of their intense fondness for their offspring they have often been obliged by the men to throw away the baby if it interfered with the loads the men oblige them to carry from place to place. Particularly if one baby arrived upon the scene before the last was able to walk did the men force the women to abandon it, and if she tried to linger near the little wailing thing - she has always been noted for her love for her baby - the man would only too often kill the child and then beat her unmercifully. I have seen a poor woman with a wound so terrible that I wondered she did not faint from loss of blood, which had been inflicted by her lord merely because he happened to be in a temper, for the women never 


\section{I50 WANDERINGS IN QUEENSLAND BUSH}

give their husbands any cause to complain if they can help it. Perhaps in the treatment they have themselves received from the whites the aboriginals are receiving back something of what they deserve for their treatment of their own gins in the days that are past.

Even their marriage customs reflect this brutality, for many of the tribes have a custom whereby the young man when he wants to marry strikes a girl a terrible blow; to see how much she can stand. If she falls under it he judges her unworthy to become his wife. Under such circumstances it would appear wonderful that the gins should ever desire to marry, but until she does so a girl is the slave and drudge of her male relations, so there seems little to choose for a woman between the two states. Now, under white rule in the reserves, she has a slightly better time, for if she desires she can have several husbands; and some of them do so, for their customs are not much interfered with by the authorities, so that a man who desires to stand well with her is obliged to restrain his temper in some measure.

Some of the early settlers gave accounts of the black men which differ very much from the generally received ideas of these poor creatures. They told that where the aboriginals were treated with ordinary kindness they returned it with great goodness of heart, and in many cases made real friends of the whites who had come to settle amongst them. Indeed in many cases the pioneers owed their lives to the kindness they met with. This is all the more creditable when one remembers the treatment the poor natives received at the hands of most of the white men, for pioneers are not as a rule chosen from 
those who "try to make empires in kid gloves"as Rhodes once said. One of these stories concerns a man named William Buckley, a convict who had escaped from Port Philip in the early days of the white settlement of the country.

It appears that Buckley, with two companions, managed to get away from the penal settlement and wandered off into the bush, where they separated. What became of the two others no one knows, but after many wanderings by himself Buckley lay down to sleep one night in a cave, where he was found next day by a tribe of blacks. Buckley was a huge man, of about six feet five inches in height, and when the blacks found him they thought he was the reincarnation of one of their own dead chieftains, for it was a common saying with them: "Lie down black fellow ; jump up white fellow." They therefore asked him if he were indeed their lost chief. Buckley, who did not understand a word of their language, nodded his head in assent to all they said, and they forthwith adopted him as their chieftain, and he lived with them for more than thirty years, living in the bush as they did, and hunting with them, and sharing their lives.

At last one day it chanced that he overheard some of them talking together of a party of white men who had landed on the coast, and whom they were plotting to murder, and Buckley resolved if possible to make his way to the coast and warn them of their danger; but not daring to tell his intentions to the blacks he set off during the night, and managed to get there in time. The surprise of the white men was great when they saw the huge old man arriving in their camp dressed in kangaroo skins; but to his own 


\section{I52 WANDERINGS IN QUEENSLAND BUSH}

consternation he suddenly discovered that he had forgotten his native tongue and could not remember a single word of English. However, he managed to make himself understood by them, and remained in the camp for ten days, at the end of which time he had recollected enough English to talk badly in that language. After this service the Governor pardoned him, and even got him a small appointment under Government, and in this post he died a year or two afterwards.

But lower than any of the blacks on the mainland were the Tasmanians, with coarse hair and features and a degraded physique. These poor wretches were shot down like wild beasts by the early settlers, until only a remnant were left; whereupon the Governor determined to round up the remainder and deport them. This plan they discovered in time, and when the cordon was drawn in only one boy and an old man were captured. The Governor was the first to laugh at his own want of success, but one of the settlers, George Robinson, undertook to manage the affair, and going alone into the bush he parleyed with the natives and induced them all to come in, when they were deported to Flinders Island, and treated well, according to the agreement. But confinement does not suit a savage people accustomed to wandering wherever they choose, and the poor remnant dwindled and died out within a few years, the last of the Tasmanians being a woman named Truganini, who died in 1876 . It is a sad thing that even when we do our best we seem unable to stay the extinction of many of the native races under our domination. Almost all are agreed that, as a distinct race the Australian blacks are doomed, though traces 



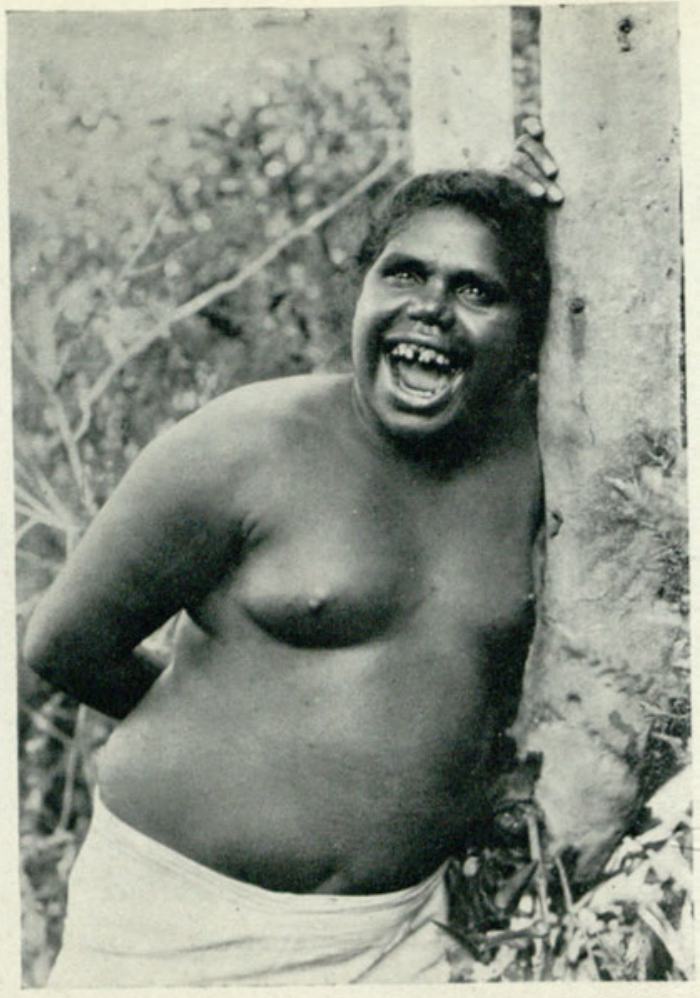

AUSTRALIAN BLACK

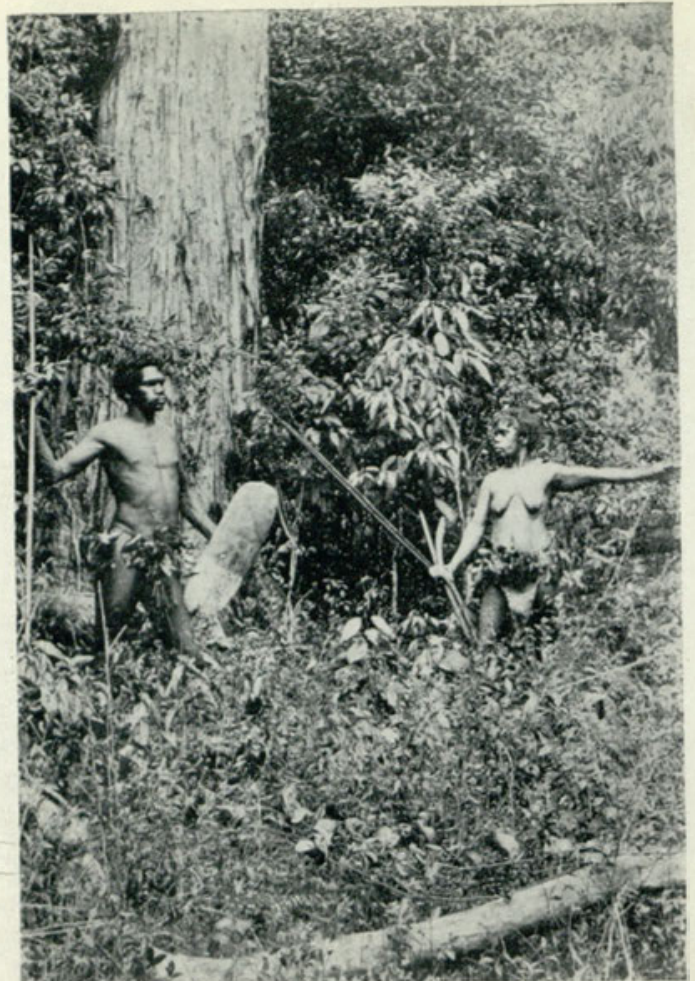

BLACKS HUNTING 
of black blood will long be visible in the less-settled districts of Australia. Possibly civilisation has come too suddenly upon the poor Stone Age men, but so it is ; and though owing to tardy measures to save them their extinction may be delayed, it is much to be feared that before very long the Stone Men will have passed from the earth.

It seems strange that with so much iron lying about the idea never seems to have occurred to them to use this material to make their tools, but instead they went on grinding and chipping stones for their various weapons. Exactly how far they could have progressed had they never come in contact with the white men it is interesting to conjecture, for it can never now be known. They have been unjustly accused of hopeless stupidity, as recent experiments have shown, but in addition to this, some of their ways are not those of imbeciles. For instance, they have managed to evolve a complicated marriage system of laws, whereby no man can marry his relations, not even his deceased wife's sister nor his cousin, and even if they had never made anything but the boomerang this instrument would reflect some credit upon the race, for they are the only ones who have discovered it and can use it to perfection. I was once fortunate enough to come upon a corroboree when the men were throwing this tool. Some forms of it were thrown along the ground until the weapon struck some object, like a tree trunk, when it bounded into the air and returned to the sender in circles. Other forms were thrown into the air, and they can cut off a bird's wing with it, and sometimes bring down several birds at a time. The boomerangs are lighted at one end for throwing at nights, as in a 


\section{I54 WANDERINGS IN QUEENSLAND BUSH}

corroboree, to show the flight, and they almost always return to the sender, the war boomerangs being far bigger than those used in play.

More than once I was fortunate enough to find fine stone axes still in use amongst the more remote natives. One old man, who was using a beautiful ironstone axe, was prevailed upon to sell it to me, though at first he refused, saying it was hard to make; but at last I got it from him upon giving him enough to buy a white man's axe in place of it. Whether the money went towards an axe or some more harmful object I did not dare to inquire later.

I once saw some natives fishing with their long spears. Some of these were beautifully barbed, either with pointed quartz crystals or with the spines of a fish called " ninagai " by the natives, which is a species of gurnard, and possesses thorny spikes close to its head, which inflict a sharp wound, as I can testify from bitter experience, having once run a spike into my hand. This recalls a cruel punishment inflicted upon the blacks by one early settler, who boasted that he never wasted shot upon a black, but if angered by any one of them he fastened them down and drove their own spears through their hands. When later on this same man was drowned while crossing a flooded river, after making desperate attempts to reach the opposite shore, one wonders if at the last he saw in his death a punishment for his treatment of helpless natives whom he and his race have supplanted. Indeed a rough sense of justice seems to lie at the bottom of the fact that while white men will not work beside a yellow man in Australia, or with a negro, they are always ready 
to work with the aboriginals, recognising, it would seem, how much they are in the debt of the latter. If only this idea had crossed the minds of the earlier settlers the natives would not now be trembling on the verge of extinction as a distinct race.

It is very hard to find out anything about the religion of the native races, but certainly they revered, and perhaps worshipped, their ancestors, whose remains when dead they wrapped carefully in the bark of the paper-bark ti-tree, and hung in a tree; and there is also a legend all over Australia of a terrible creature, known as the Bunyip, which inhabited certain water-holes amongst the mountain ranges and which was half-animal and half-human, which came out of the holes at night to devour human beings when these could be caught alone. I was shown more than one such hole inhabited in olden days by a Bunyip, but which it would seem has retired with the natives before the white race.

When crossing a creek inhabited by crocodiles, who seem to be more terrible to-day than the Bunyip himself, the natives always force an old woman to cross behind all the rest, believing that the crocodile always takes the last of a file of people, for most savage races think very little of aged people and cheerfully leave them to perish if by so doing they can save the younger members of the tribe. When on the march from one settlement to another these are only tolerated as long as they can keep up with the rest : if they fall out they are left to their fate, which usually means perishing for want of food, which they are no longer able to procure for themselves, But in the matter of obtaining food the blacks were not in any way behind many savage races. They 


\section{I56 WANDERINGS IN QUEENSLAND BUSH}

had made nets from kangaroo thongs for snaring emus on the banks of the creeks. Fibre was made from several plants and trees, such as the pandanus, and with this they made coarse clothes for cold days, for the winds on the heights of Australia are very piercing ; and they could also catch the wild animals, for their clothes were made of wallaby and kangaroo skins which they had caught. Added to which their powers of tracking are so well known and appreciated that even now black trackers are always attached to the police to track down criminals or animals which have escaped. Therefore they could not have been altogether devoid of brain and intelligence. If they had been left to themselves they might have become settled in their habits; though with no domestic animals to tame, and of which to form flocks and herds, there would never have been any inducement to abandon their nomadic lives, and this would have militated against their becoming what we term " civilised." The only animal of which they ever made any domestic use was the dingo, which they used to help them to run down game.

Where the blacks of the mainland came from in the first case is not known. They are not of the same race as the Kanakas of the South Seas, and the only way in which it seems possible that they entered Australia was from the north-from Asia-when at some time or other that continent was joined to Australia by some land-bridge. Parts of Australia are known to have been raised and lowered several times in past ages, and in one of these convulsions of nature the men from the south of Asia may have crossed with the wolves from that continent, and later on been separated from it before more of either 
race joined them on what had, perhaps suddenly, become an island. This would explain how it was that the dingo drove the earlier marsupial wolves and devils out of existence on the mainland of Australia and left them to linger on the island of Tasmania, where they were protected by the Tasman Sea from their more advanced rivals; while the earlier type of men of the mainland also were left, a miserable remnant, on the island of Tasmania, till the last of them, a mere handful, died of broken hearts on the island to which they had been deported.

As it is, when white men found them, the aboriginals were fairly numerous, while at this moment there are only a few - a very few-thousands left in New South Wales, while all over the continent there are not more than about thirty thousand in the various reserves, and a few more tribes still wander in regions not yet settled by the whites in the north and west. How long the race will last it is not easy to foretell, but that it is doomed as a distinct race is practically certain. White men now too late recognise their obligations to the remnant of the people they have supplanted, and are showing them kindness at the last. No one now would boast that "he shot at sight, thirty-nine up to the present," but many whites owned to me that they would be relieved when the last black had disappeared, as they did not desire " a coloured question," as in the United States, for instance, but that is not a fear in Australia but a mere expression.

When they have disappeared there will always be one memory of them left, in the shape of the numerous names given to the townships all over Australia, and the habit of calling places by their native names 


\section{I58 WANDERINGS IN QUEENSLAND BUSH}

is infinitely better than when such places are given names like "Smithville," " Oil Springs," etc., so common in new countries. There is something poetical in such names as Boonara, Wagga Wagga, Woy Woy, and numerous others. And it is due to the dispossessed owners that at least the names they gave-often of very poetical meaning - should remain as a monument of the far past.

By the way, the habit of repeating a sound is a superlative in the native tongue, meaning such things as "big big " river or "good good" water. They do not count higher than five, making up the number by saying "two two one," their only words for counting, though their language, in Queensland at least, is rich in grammar. All the places named by them have some meaning, such as "Gympie" = "paper-bark ti-tree "; " Beerburrum "=" parrot"; "Beerwah" =" big hill," etc. And they reckoned time by sleeps and moons, as so many other primitive peoples have done.

Whither they were tending as a race will never now be known, for civilisation has come upon them too suddenly; and in all cases where an animal or race comes in contact with fresh conditions it is decreed that it must conform to these conditions or perish. Other races more adaptable may survivethere even seems a faint hope for the Maori nowbut not for the poor aboriginals of Australia.

I remember a most striking scene in which I once took part in Queensland. It happened that I reached a settlement on a Sunday when a "bush brother," who chanced to be in that neighbourhood, was to hold a service in the little bush church there. The blacks in the reserve were allowed to attend the 
service, and some of them did so. I shall never forget that evening. There were only two or three whites present beside the Head of the Reserve, the rest of the congregation being made up of the blacks. So there one saw the representatives of the Stone Men - the last poor remnant of the men who had once owned the earth-side by side with those who represented on their part the last word in modern civilisation. One line of a simple hymn we sang struck me and has remained in my mind though I have forgotten the rest :

"Life's poor distinctions vanish here."

I could not help thinking that there was a parallel between the decaying race and the dying day, for the little windows were open and I could see outside the silver and gold sunset behind the gum-trees; and I wondered if we too should one day pass away, as these were doing, before some newer development of the human race, leaving only a few traces of our sojourn here as they had done. And then the service came to an end, and we walked home in the dying light, with the beautiful Australian haze lending its magic to the bush all round us. 


\section{CHAPTER XIII \\ ON THE PLAINS}

I THINK one of the things which makes Queensland so interesting is the great diversity in character of the various regions there. First come the eastern scrubs with their rich, often tropical, vegetation, then the chains of highlands, and then the plains leading to what Professor Gregory calls the "Dead Heart of Australia." These plains begin within twenty miles of the Main Ranges, and spread away towards the west - a rich red country with blackedged streams and rivers running through it, until the grass runs out into thin bush, such as salt-bush and mulga ; and then come the plains covered with pebbles, mostly quartz mixed with red gibbers, polished by the sand which blows over them. These are due to the breaking up of the desert sandstone which once covered these plains when the vast inland sea dried up.

Upon these plains millions of sheep feed now, thriving enormously when the weather is favourable, but when a drought or floods occur they are left to perish. And this is the great artesian basin which underlies most of Queensland, and which is being more and more tapped by bores, which are drawing out the water held against the shale beds far below -though how it came there is not yet settled by geologists, some holding that it is the remains of the ancient sea, others that it is the leakage from the 



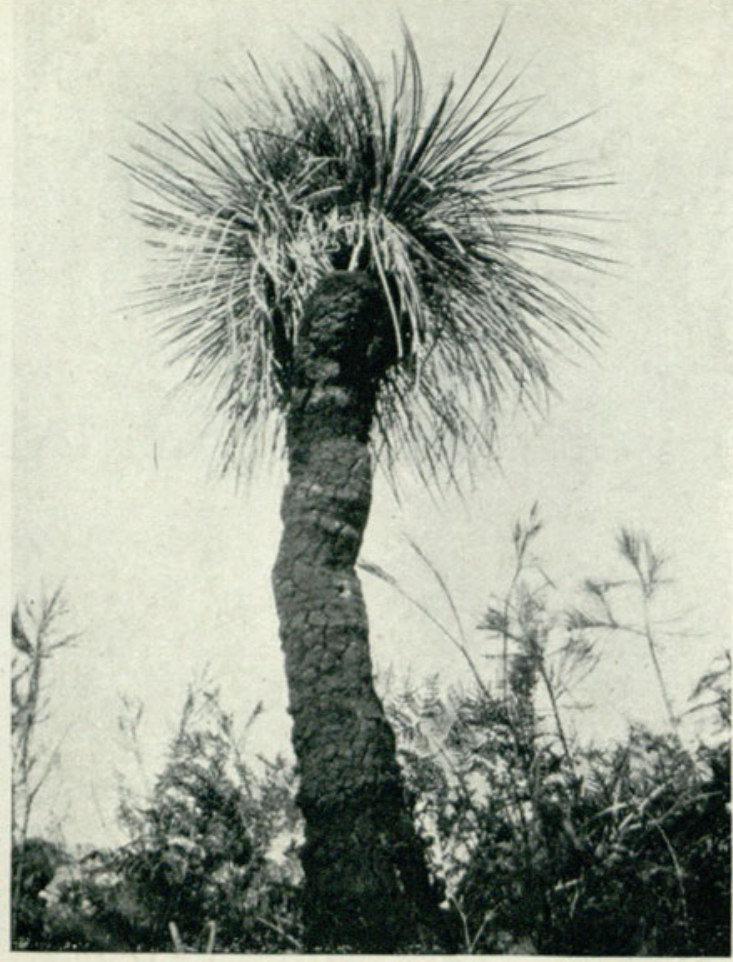

GRASS-TREE

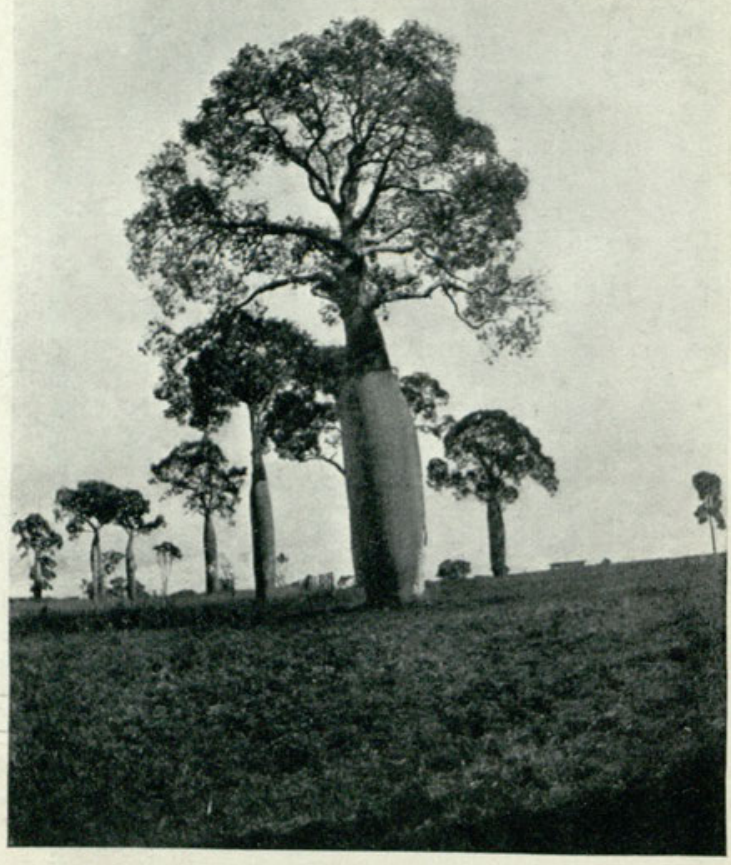

BOTTLE-TREE 
rivers after the rains from the mountains to the east.

Here and there in the drier parts a spring is found which is warm and bubbles out of the ground like "boiling quicksand," as someone has described it. Sometimes it forms a huge bubble and then falls back and breaks; and indeed all over the artesian basin the water obtained by the bores varies, both as regards the temperature and the quantity of salt it contains. In bygone ages, when the vast inland sea had disappeared, the desert was probably full of these springs, filled with warm water, which bubbled up in all directions, and formed in time the rims of lime sinter which are the " extinct craters " of to-day. Now only a few of them are still alive, and the increasing dryness of the "Dead Heart of Australia" will cause these to dry up in time and to fill with sand, as the remaining water below is more and more tapped by the bores.

One interesting proof that this dry, arid desert was once connected with the coast by rivers and lakes, even after the sea was gone, is found in the fact that near a few fresh-water pools are still to be found a species of earth-worm which is also found near the coast on the east of the continent. No worm could possibly have reached this region as it is at the present time, owing to the surrounding deserts, and no one can have imported it. But the fact remains that this is a variety of the earth-worm family known as $N$. eremius, of an earlier type than the common worm which has now conquered its rival in the coast regions, banishing the earlier worm which once spread all over Australia. The older form is still found in such places as New Zealand and Papua, and several other 


\section{I62 WANDERINGS IN QUEENSLAND BUSH}

spots once connected with each other by some vast lost land.

But it is in the parts where sheep can live that one can best study the life "out back," and see the shearers and drovers at work. And these seem to me to be the best type of Australian to-day. There is what we should call a manliness about them which enables them to go through every form of hardship without a murmur. If a man has luck he "makes good," if he does not, he "takes it all in the day's work," as he says. And they seem able to turn their hand to anything that comes along. I know one man, for instance - there are thousands like him in Queensland-who has a "selection," which he has cleared, and he has now gone out to work for others until his crops begin to come in. He has been shearing at Longreach and droving on the Burnett. He was cutting cane at Bli-Bli when I saw him, and later I heard he was in the sawmills near Brisbane; and I am sure he could have done a dozen other things all equally well. And all through everything he and his mates would show the same good nature and " mateyness," and the same pluck and resource.

As regards horses, I believe the Queenslander of the plains can do anything with a horse which mortal man can do. He loves everything in the shape of a horse, and helps to breed it and break it in, and ride it and race it, and bet on it-even if it is his last shilling which he puts down. And to see him rounding up the sheep, or " cutting out " a brumbie from a herd of wild horses, and shoeing it later on with the help of a mate or two, is a sight not to be forgotten.

A picture of life on the plains has been written by 
a Queensland poet, who has himself since passed "over the Great Divide," which gives a very true feeling of the life lived upon them by the ordinary men and women of to-day. A few of the verses run :

"Here where the days are dull and gray

And youth has stilled his joyous song

In fancy yet I love to stray

By creek and plain and billabong,

To the curlew's call

And the noiseless fall

Of the unshod hoof 'neath the gum-trees tall.

I hear once more the plover's " peet,"

The grey hawk wheels in dizzy flight,

And swift beneath my horse's feet

The brown quail rises in his fright;

And the galahs fly,

With pink breasts high,

A rosy cloud in a cloudless sky.

Afar I mark the emus run,

The bustard slow in motley clad;

And basking in his bath of sun

The brown snake on the cattle-pad

And the reddish black

Of a dingo's back

As he loit'ring slinks on my horse's track.

Slip girth and let the old horse graze,

The noon grows heavy on the air,

Kindle the camp-fire's tiny blaze

And 'neath the shade as monarchs there-

Take thou thine ease :

For hours like these

A king has bartered satrapies!"

I met a man who was "taking a spell " on the coast one day, who told me of his arrival some years before on the plains, where he had gone in order to offer 
his services in a shearing shed. He arrived as he would have done at his London office: in a neat suit, a collar and tie, a billycock hat, the whole finished off with a smart cane. The men were just streaming out for one of their numerous meals when they caught sight of him. Now the Queensland working dress is a shirt-or what remains of it-open pretty well down to the waist, with a good deal of person showing through in many cases; dungaree trousers-often slept in as well-and sometimes no boots on, with a slouch hat of any shape the weather has left it in. When they go into a "township " they usually put on boots and a whole shirt, otherwise the costume is the same. When, therefore, they saw my poor friend they gathered round him. "What's inside?" asked one. "Dunno; poke it with a stick and see if it bites." "Blime, I b'lieve there's only a pommie in it after all," etc. Now the word "pommie" seems to have had many derivations, for I have heard a good number ; but the most likely is the one an old settler mentioned when he showed me a fine garden of pomegranates: "Here's where pommies come in, for when they meet our sun they gets burnt up like a pommiegranite "-which word is the Australian for pomegranate.

When my friend the pommie met the "boss" of the shed a few minutes later, and offered his services, the man, to try his mettle, told him to ride "that horse " round the yard, the said horse being an ancient, wall-eyed creature, with its head drooping and a lack-lustre look in his eye. He accordingly mounted, when a change came over the brute, and whisking his long tail his apparently aged eyes caught fire, and he tore off round and round the yard-bucking, kicking 
and jumping. My friend hung on as long as possible, but at last the inevitable happened and he was thrown into a pool, where the old brute rolled upon him. Picking himself up, he was surprised to find that the men were pleased with his grit, and several of them offered their help in trying to clean his "flash" clothes: one even brought him his cane as a consolation. The boss offered to take him on trial and to find him a shearing mate, and later on, in the dinner-hour, he came up and said confidentially : "For Gawd's sake, sir, shove a 'ole in that there roof." After this all went well till the shearing at that station was over and my friend left.

The shearers are paid by the fleece, and I asked one of them how many could be shorn in a day. $\mathrm{He}$ replied that a few of the men could do as many as two hundred ewes a day, for which they receive pay at the rate of two pounds a hundred at present, though the amount varies now and then, but very few can accomplish as many as this, a hundred and fifty being considered a very good number. Out of this pay they have to find their own cooks and " keep," while the rouse-abouts, who only receive three-pound-ten a week, have their board and lodging found for them.

And I must here mention a man I several times met in Queensland, and with whom I travelled for some weeks-I mean Bishop Halford of Rockhampton. This man has resigned his bishopric, and given up all his worldly goods, to become a "bush brother," which means to put himself at the disposal of the authorities to be sent into the bush in any capacity and wherever they may think well. When I knew him he had been at work amongst the shearers at Longreach, and shared their work with them, ready 


\section{I66 WANDERINGS IN QUEENSLAND BUSH}

to cook for them, or anything else that was required. I wish he could have heard them speak of himthough I know well enough he did it for no earthly reward but to follow in the footsteps of the Master he followed. One shearer-a Roman Catholic, by the way-remarked to me that though he was not of the same faith as the bishop he would go anywhere to hear him speak, for whatever he said was sure to be right. I do not know if Dr Halford will see these lines, and I feel sure he will not appreciate them, but I feel it a duty I must discharge to say here what I could never have said to him.

When the sheep are to be shorn the musterers go out to round them up, and this involves riding very many miles after them. This is no uncommon thing in Queensland, for domestic animals are left to find their own living, and very often - especially in bad seasons-they go far afield for it. When a man wants his horses he sallies out upon one of those who are in work at the time, taking ropes to catch one or two others who are "somewhere," and you can see him riding over swamps-or through them-and across country or bush in search of them. When found he drives them in. Sometimes he will have to bring in a huge herd of cattle to brand them, or to dip them, or for some other purpose, and then one realises what Paterson means when he writes of the drover's life as he does in Clancy of the Overflow:

"As the flock are slowly stringing Clancy rides behind them singing,

For the drover's life has pleasures that the townsfolk never know. And the bush has friends to meet him, and their kindly voices greet him

In the murmur of the breezes and the river on its bars; 
And he sees the vision splendid of the sunlit plains extended, And at night the wondrous glory of the everlasting stars.

And I somehow rather fancy that I'd like to change with Clancy, Like to take a turn at droving where the seasons come and go ;

While he faced the round eternal of the cash-book and the journal-

But I doubt he'd suit the office, Clancy of the Overflow."

I used to like to watch the men coming in, with a piece of wattle sometimes stuck in their hats, and singing or shouting as they brought in the cattle to the yards. Sometimes when the musterers are out for days they have to take tents with them, for the distances are great, and sometimes a paddock contains thousands of acres; and the tent life itself is pleasant in that warm climate and the fires at night, with the billies boiling, was a cheerful enough sight. I can fancy many a worse life than a stockman's in the bush.

Here and there, as one advances towards the barren regions, one comes across a fence against which are banked many of the curious remains of a bush which looks like a white sponge. When it dies it detaches itself and rolls along the ground for many miles, looking like a football, and when it meets a fence it rests there, and gradually gets covered with sand, and this bank rises to the top of the fence; for the sand-storms in the desert regions are very severe. One station-owner lost five hundred sheep on one occasion by their blowing into the creek, being unable to keep on their feet in the dust and wind, and sometimes such a storm gets to the eastern part of Australia in the form of a dense cloud overhead which blows for an hour or more at times.

In the barer portions less and less grass is to be 


\section{I68 WANDERINGS IN QUEENSLAND BUSH}

seen, and the rabbits are eating much of what there is. They are doing other damage too, for they are ring-barking the bushes out of existence, one kind in particular, the beautiful leopard-wood tree, which is like a silver birch in shape. Patches of mulga bush grow here and there, and in moist places the marsilea, from which the aboriginals made their bread, and the salt-bush grows too for acres on end. This bush has tiny greyish green leaves, and gives out a horrible smell after rain; but the sheep can eat it if necessary, and this is all-important in a region where grass cannot grow unless it be of a kind whose seeds will germinate after waiting for a favourable season for many years underground.

A most wonderful effect upon the plains is seen in the early morning, in what is called "the foreglow," when the sky suddenly becomes of a brilliant orangecolour and this fades to grey ; after which, when the sun is rising, it again begins to turn to pale yellow and pink, and then the day is begun. I never saw this effect in any other part of the world, for it is in the mists and colours of Australia that its chief distinction lies.

In the gem districts of Queensland one sees masses of "potch" lying about; this is like cloudy quartz, with a gleam as of opal here and there, for here is where the opals come from. I saw one black piece of stone broken open with a hammer. It looked like a ball of iron pyrites before breaking, but when opened I saw the loveliest red opal that could be imagined. It is not known what produced the opal, but it is sometimes thought that it is the result of the blazing sun acting on quartz in arid regions, or it may be the action of water in those burning plains 
where once the great sea rolled. However that may be, there are opals of every shade of blue and red, looking like a rainbow in stone; and farther to the east are the sapphires-for most of Queensland is gem-bearing - and these are found in high lands amongst the remains of the basaltic crags where they were first formed. They are of every shade too, from the white colourless sapphire to the blues of every imaginable tint. One stone I loved in Queensland, and that was the zircon, of many shades of yellow, from pale primrose-colour to deep brilliant orange ; not for the value of these gems but for their beauty I loved them.

Wandering in the desert you look over what look like miles of tomatoes, from the broken stones lying about and rounded by sand. And everything points to ever-increasing drought in the " stony desert," as every year more water is being drawn away from beneath by the bores, which are being sunk in increasing numbers by the sheep- and cattle-owners in the stations lying towards the east; but most of the bores are now reducing the output, some by as much as seven per cent. a year, as the water below grows less. Long ages ago, when Australia formed a vast continent spreading over what is now the Tasman Sea, this inland sea must have separated the highlands on the east from the western plateau. In those days sandbeds were laid down there, and upon them thick beds of clay, which have now become shale-beds, and in Queensland these sand-beds are now thousands of feet below the surface. Then gradually the whole surface was raised, and folding occurred, the eastern beds being turned on end and forming the beds which now hold the water. Bores have been sunk 


\section{I70 WANDERINGS IN QUEENSLAND BUSH}

in almost every part of the artesian basin to draw upon the water held below. Unless they are sunk far enough the water is so salt that it is useless for stock, and one station-owner with whom I stayed told me that several of his bores were useless owing to this cause. Farther to the west occur those strange formations known as mound springs, where even now in some cases water oozes up round the rim of the "crater," which is built of sinter by the action of the water, but most of them are extinct now owing to the increasing aridity of the climate. Some of these are near Coward Springs, and one of them lately described was still alive and held a pool of water. But it also held a dead horse, which had been bogged there, within the rim of the crater, around which grew clumps of panicum.

Horses and cattle are often bogged in their attempts to reach the water in swampy ground, and one writer described how she saw a horse sunk to the neck in the swamps of the Northern Territory, the head still trying to reach the grass which grew around, of which he had eaten all within his reach. It is very difficult in most cases to get an animal out which has been bogged, as it is risky to approach too near the treacherous soil, and sometimes in trying to get an animal out its tail is pulled off. I myself saw a horse which had died as the result of the severe dragging he had received in the effort to get him out of the swamp, which sucked him back every time he was almost saved.

Some of this desert region, as I said, is growing more desolate as time grows on, for the white men at least are forsaking the most arid parts. Thus Coward, for instance, which was a small "township" 
twenty years ago, now consists of four houses, and two of these are shut up, while the train stops there now only once a fortnight. For of what use is a plentiful flow of water if no green thing can live and thrive near? And indeed even in less arid districts it is necessary to have a "station " covering many thousands of acres even to make a bare living, for it takes several acres at least to feed a sheep, in some parts fifteen acres or more, while in times of drought many more still are required per sheep. I have seen farmers carefully transplanting a single plant of grass and replanting it near water in the hope of saving it for the future use of their animals.

The number of sheep in Queensland is enormous, even in spite of the recent terrible drought, which ended in February I92I - though there was a setback in I922-for the country is so rich in the pastoral districts that it recovers sooner than one would think possible, and at the present time it is estimated that there are about II,000,000 sheep in the state and over 2,000,000 head of cattle. At Longreach, for example, which is one centre of the wool industry, the output of wool is growing. But the rabbit pest is threatening the sheep-farmer in the arid regions more every year, for they nibble off the young sprouting grass which is struggling to grow after a flood or a drought and kill it. They also kill the bushes by eating the bark and ring-barking them, so that at the present time it sometimes takes fifteen acres, or even more, to maintain a sheep. I was told of 3000 rabbits being poisoned at one water-hole alone within a week.

Ticks are amongst the worst pests to overcome, and in some places the grass seems full of them, lying 


\section{I72 WANDERINGS IN QUEENSLAND BUSH}

ready to spring upon any living creature which passes near them. When they have got hold of an animal they stick to him with a grip which nothing but death relaxes, and which can only be cured by dipping. These horrible little creatures, unless removed, cause swellings upon the unhappy beast which at last cause tick fever, and even if the beast does not die it seems to paralyse his hinder quarters, and you can see an animal so afflicted dragging its legs behind it ; this does not seem to be curable, and the animal seems thenceforward unable to recover the use of its limbs.

Here and there, beside a creek or pool, one comes across piles of the remains of an aboriginal camp, with flakes and bits of their tools which had broken in the making, and sometimes it is possible to find fine celts and other reminders of the past amongst them. I once found a beautiful axe-head beside such a pile, and once I saw the two stones wherein they had been grinding nardoo, as they do at the present time in remote places. Here and there, too, you can see the " desert varnish," as it is called, which is caused by the action of the hot sun drawing the iron salts to the surface, when it imparts a bright varnish to the stones and sand there.

Some years ago a scheme was much talked of which was to let the waters from the Gulf into the centre of Australia, and thus to return to the conditions of past ages; but this was knocked on the head by Professor Gregory and others, who declared that it would not only cost hundreds of millions of pounds, but that within thirty years the sea would again be dried up, and the only result would be the filling of the bed of Lake Eyre-one of the few remaining lakes-with a bed of salt, owing to the 
evaporation; for in the drier parts of the desert the rainfall is about 5 inches a year and the evaporation is about 120 inches. So the scheme was abandoned ; and it appears as if the centre of Australia will ere long be left as Nature left it, and to the few aboriginals who still wander there.

But in the regions before you reach the Stony Desert the scenery is very like England, for the plains are green, and the rivers flowing peacefully along in their shallow beds are very like some parts of the old country - though you would not see gums at home bordering the streams; but the cows and sheep are there, and wild birds such as duck in thousands, and the crane of Australia called the native companion, besides other native species; and here and there are lagoons of lilies, pink and blue or pale purple; and upon the leaves are the little larks running about and catching the insects. And here and there you can see the roof of a homestead amongst the trees. But these are few and far between, for the sheep and cattle stations are large in Queensland, and nowhere in England could you find any country so thinly peopled.

Sometimes the man " out-bush " has to take a herd of sheep or a flock of cattle over immense distances for the sake of food, or when they have been sold, and the distances they cover are enormous, as well as the difficulties they have to encounter on the way. In bad seasons a terrible number of the animals die on the way, and at all times it is hard to procure enough food while moving across country along the villainous tracks from one part to another. Some of them come from the borders of the "Never," and have to be taken right across the country, and the 


\section{I74 WANDERINGS IN QUEENSLAND BUSH}

work accomplished by the stockmen would do credit to one of the celebrated pioneers in the resourcefulness and pluck they display. But they make nothing of it-"it is all in the day's work." When they arrive at the "station "-perhaps a number of them together-and you see the bronzed faces and their hard, healthy appearance, you recall some such stirring lines as those of one of their poets when he says :

"It was pleasant in the glowing morning among the gleaming grass

To wander as we wandered many a mile.

It was merry midst the black-woods when we spied the station roofs

To wheel the wild scrub cattle at the yard

With a running fire of stockwhips and a fiery run of hoofs$\mathrm{Oh}$ ! the hardest day was never then too hard."

And the evenings spent gathered together round the fire or, with luck, round a piano, if such a luxury can be obtained, is another of the pleasant memories one retains. I shall never forget one place, where a number of us gathered on those beautiful hot nights, for one of the party had managed to buy a piano and another had obtained some music, and I was fortunate enough to be able to play well enough to give pleasure to the boys - but much more to myself ; and to hear them singing some "bonzer" song which I had often heard in very different surroundings, far away in England, in their rich happy voices, added another to the memories gathered around the song and the distant bush. Some of those songs I heard out in that far-off corner of the Empire I shall never hear again without the memory of the faces gathered round the piano while I played; and a pang of longing 


\section{ON THE PLAINS}

will come over me to be back with the boys out there again instead of in the " man-stifled" towns, which always weary me, whether they are placed on the banks of the Thames or the Hudson or the Fitzroy river. 


\section{CHAPTER XIV}

\section{IN TROPICAL QUEENSLAND}

PERHAPS the best way of getting about in the north of Queensland-that is, if you wish to leave the beaten tracks-is to go up one of the rivers there. You can land and walk past masses of rotten coral, and past lagoons filled with thousands and thousands of wild fowl of all sorts, geese, wild duck, spoonbills, storks or native companions, pelicans and many others, and if you wish to shoot for the pot you can get enough in an hour to supply all you can possibly want.

There are mangrove swamps at the mouths of most of these rivers, for the Queensland rivers bring down so much silt that the mouths are usually very wide and shallow, with huge estuaries, and it is easy to understand here how the coal measures of the past were laid down. And if you walk amongst the mangroves you can usually manage to walk on the numberless roots, and so keep out of the evil-smelling ooze beneath. Some of the mangroves send down their pod-like seeds towards the water, and at other times they throw down roots and the ground beneath is covered with their pretty red flowers.

Perhaps as you get higher up the river and reach firm ground you will come round a bend and see a stretch of grassland, and here you may see a herd of wild horses feeding or lying about ; for there are now quite a number of wild animals in Queensland 



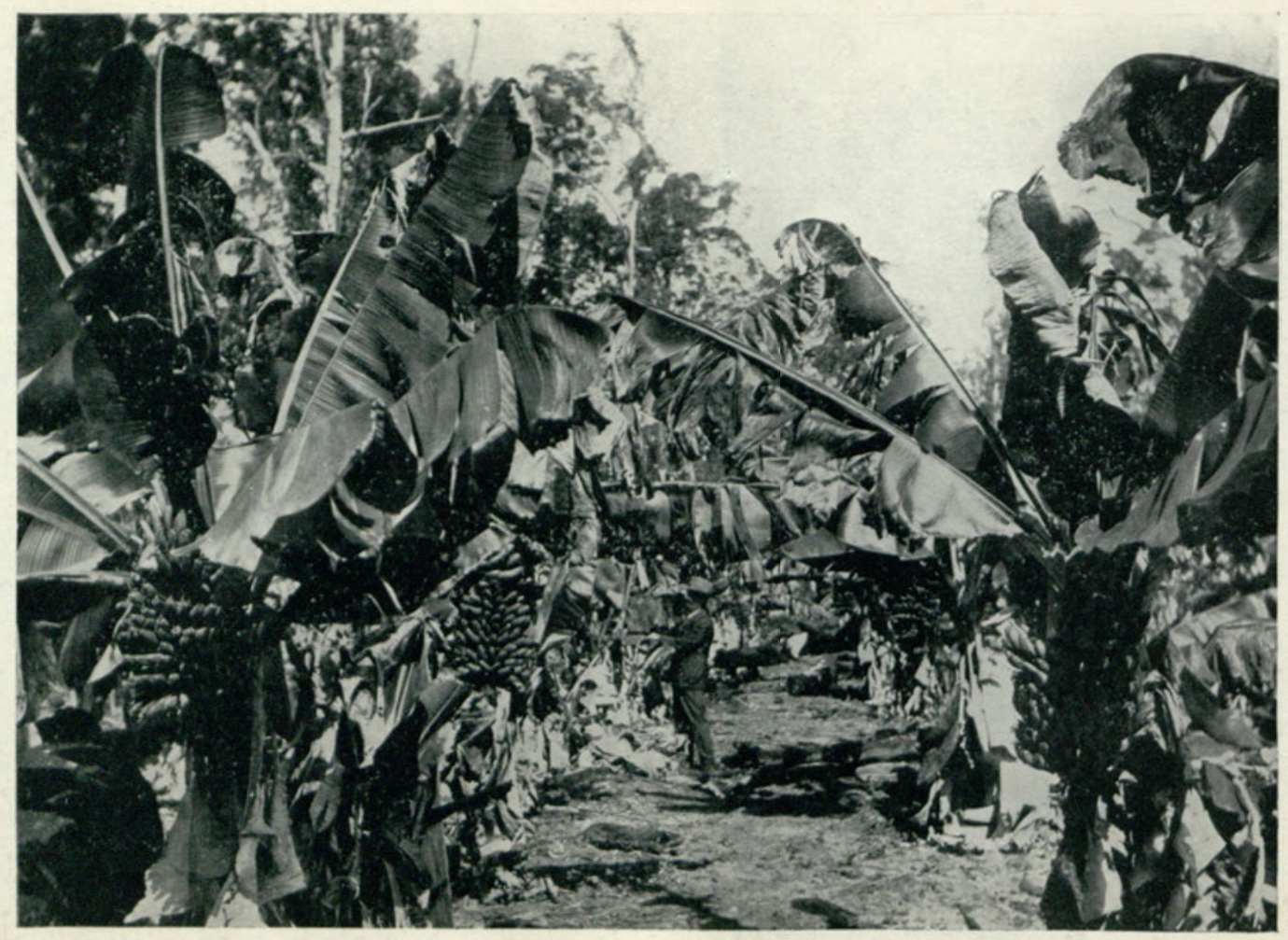


which are the descendants of those brought by the settlers; and these numbers are increased from time to time by "escapes" from the stations. I saw a herd once which had been joined a year before by a stallion from one of the stations, and he was now as wild as they were. These wild horses always keep a sharp look-out for human beings who may be going to follow them. The wild horses of the north seem to be getting smaller, something like our mountain ponies-perhaps owing to the climate.

In the "good old days" men who had gone " off the rails" and had become outlaws were in the habit of taking to catching these horses for a living. They would take up their abode on the "Never," not too far from the borders of the territory, and if pursued they made their way over the borders. They would catch a "brumbie" by riding him down and cutting him out from the herd, break him in and sell him; sometimes to this industry they would add that of " cattle-duffing," for many of the cattle ran wild in order to get their living, and it was no hard matter to shoot one of these for food. One gang in particular, led by a man known as "The Queensland Orphan," numbering about sixteen, lived on the borders and made a very good thing out of capturing calves or colts which had not yet been branded and selling them after marking them with their own mark. Even to-day, in out-of-the-way places, this is not a difficult thing to do, for until the calves are marked they cannot easily be identified by their owners. The one thing creditable to the " Orphan " and his gang was that they never robbed a small station nor a poor man, and indeed they often helped 


\section{I78 WANDERINGS IN QUEENSLAND BUSH}

one along. They would meet in the drinking shanties on the borders and discuss future plans, and they were never broken up by the authorities, though at last they gradually broke up of themselves, and took to a settled life, having secured enough plunder to enable them to live in peace. These answered to the bushrangers of the southern parts of the colony, for when anyone " down south " had gone " on the crook " he would go off and join "Thunderbolt," or one of the other leaders, and thenceforth he became an outlaw like them. Almost all the men were " hard cases," who had gone under from a civilised point of view.

In wading or walking beside the rivers in the north one has to keep a sharp look-out for crocodiles, for these lie in the ooze ready to snap up any unwary walker, and so closely do they resemble the logs which lie about everywhere on the banks of rivers in Queensland that they are easily mistaken for one. One man who had gone down to wash his clothes in the stream got on to a crocodile, thinking it was a $\log$, in order to wash; but finding his log moving beneath him he got off, only just in time. And these animals can go pretty fast, for one of them in pursuing a dog up the bank, where he had been down to drink from the river, went after him at such a pace that the dog had to run hard for his life; and dogs often perish in this way when they are out retrieving birds for their masters. Though the crocodile is supposed to be a slow mover, one was seen to turn a complete somersault in order to catch a native who was standing behind him. These natives are said to make for the eyes of a crocodile which has caught them and to try to poke them out, but this must be difficult 
when once the monster has got hold of one of them.

These reptiles are increasing in the rivers of the north now, owing to the natives ceasing to collect their eggs for food. In bygone days they were very fond of them, but now they have found it easier and safer to obtain other kinds of food, so that the crocodiles are left to hatch out in peace on the warm banks where the eggs are laid; and their numbers are likely to increase still further, as the blacks retreat more and more. While as they can subsist easily enough upon the thousands of wild fowl in the creeks and lagoons they will never be at a loss for food.

Walking beside these rivers in the north is not always an easy task. Now and then there are wide spaces, but these are usually caused by lagoons, for the rivers here have low, wide banks, owing to the floods bringing down so much soil. These floods are exceedingly rapid in their rise when the storms break in the mountains, and then they sometimes cover miles of land with water. One writer mentions having seen the carcasses of bullocks as high as forty feet from the ground in the trees; it was probably in some such flood that Leichhardt was swept away, for his expedition was making for the Gulf when last heard of. He probably camped on some rising ground between the rivers and a sudden flood covered his camping ground, and he and all his camp must have been swept into the Gulf, otherwise some traces would have remained to be discovered later.

In the dense growths on both sides many lovely trees and creepers are to be seen. Lawyer-vine, or calamus, grows between the trees and is so tough 


\section{I80 WANDERINGS IN QUEENSLAND BUSH}

that I never succeeded in cutting through the thicker vines with a clasp-knife, though I tried many times to do so when I wanted a rope. And various palms throw their graceful shade, fan and cabbage and phœnix and several other varieties, and near the coast numbers of beautiful pandanus palms, twisted into endless shapes. And wild bananas of various kinds grow here, and hibiscus of several shades, and wonderful orchids in the forks of trees. And sometimes I saw ferns of absolutely monstrous size-elkhorn and bird's-nest ferns with fronds many feet in length; and the pink coral-tree, and the wisteria, with trails of blossom; and the ginger, with its pretty white flowers; while creepers hung from many of the trees.

In less crowded places the ground is covered with masses of huge convolvulus flowers, pink and blue and red; and pepper, with its yellow flowers; while one species of cotton grows everywhere and throws its white fluffy seed-pods all over the ground. And through these woods fly multitudes of birds : sulphurcrested and black cockatoos, and fruit pigeons and rifle-birds, and numberless others. A curious story is told by Mr Le Souief of a sight he saw on one occasion, when an iguana had been trying to rifle a cockatoo's nest in the hole of a tree for the sake of the eggs of which he is so fond; for Mr Le Souief saw him half in and half out of the hole, with the parent birds holding on to his tail and trying to drag him out of the nesting hole. The kookaburras also build in holes, but they often bore these in the nests of the tree ants and lay their eggs there, and I well remember, when photographing one such nest, the way in which the parent birds set up their harsh laugh when they saw me suddenly fall with my camera into a bush 
near. This laugh sounds mocking in the extreme at such moments.

It is a great pity that so many of the beautiful Queensland flowers either have no popular name or are given such ugly ones. Time after time I asked the name of a species, only to be told: " $\mathrm{Oh}$, it is some bush thing," which I already knew myself. Or a lovely orchid is called " donkey flower," or the mauve flower which covers the sand-banks near the sea, which we know on our rockeries as Mesembryanthemum, is the "pigface" of Queensland. Contrast these and many other names with the beautiful old English ones of which Kipling says :

"Alexanders and Marigold,
Eyebright, Orris and Elecampane,
Basil, Rocket, Valerian, Rue-
Almost singing themselves they run;
Vervain, Dittany, Call-me-to-you,
Cowslip, Melilot, Rose-of-the-Sun,"

Probably some of the love we bear these old flowers-besides their associations-is due to their beautiful names. It is hard to associate poetry with "fat hen," or " blue tongue."

On the eastern coast the rivers are not so shallow as a rule as they are in the north, and before long you are in the hilly country behind. Unfortunately the climate does not help one to activity for it is extremely hot and damp-almost steamy-during most of the year. At Cairns for instance, even in the winter, the thermometer marks $100^{\circ}$ in the shade soon after breakfast, and in the summer you find yourself in a steam bath. Off the river mouths there is no end to the fish waiting to be caught. Farther out towards the Great Barrier Reef there are gigantic 


\section{I82 WANDERINGS IN QUEENSLAND BUSH}

groper, weighing up to six hundredweights or more ; rock cod of more than three hundredweights ; barramundi of thirty-five pounds, and mullet and schnapper of various kinds. The best bait is a prawn, and these are of a quite ridiculous size in Australia. I saw some being sold in the streets of the towns of which two or three at most would be a fair breakfast, and some of those caught in the north when stretched out are a foot long from point to point. If you land in the early morning before the world is astir you are met by what someone has called " a church-like silence." In the night many things are stirring, and the screams of the flying foxes and the wails of the curlews and the solemn call of the boobook or mopoke keep on all night; but in the early dawn everything is still, and a walk in the morning in Australia is a memory not to be forgotten. And then the magpies begin to carol and the day is beginning.

As you walk on the outskirts of the dense scrub you must look out for nettle-trees, which usually grow there, and a little inland are beautiful " cedartrees" which are not cedars at all, but belong to the meliacæ (C. toona), and beautiful kauri pines. Another curious tree is the flycatcher, whose seeds are prickly and get into the fur of any animal which chances to pass below and irritate him exceedingly. Amongst the hills are narrow valleys with rugged sides, such as the gorge of the Barron river, with its wonderful falls. In the flood time this river brings down more water than Niagara, but in the dry weather it diminishes to a narrow series of falls about seven or eight hundred feet in height. From the railway bridge over the valley you look into the 
densest vegetation one can imagine below, with the rivers winding between it in their rocky beds here and there, and numberless beautiful little mountain streams falling in cascades-many of which seem to have no names as yet.

The narrow roads wind up gullies with vegetation on both sides almost choking the road, or rather track; for as someone has said: "In Queensland there are roads near the towns and farther out there are something like roads-not much" ; to which I must add : farther still there are only practical jokes. But the beauty of everything all round you atones for many things.

Sometimes in the middle of the bush you come across a pool or lake where one of the streams has widened out, and here you stand at the margin and see numberless water-lilies, of many shades, with birds upon them, and perhaps some wild pigs or cattle coming down to drink there. And turkeys are all round one in the bush, with their huge mound-nests ; while some of the lakes near the coast are filled with beautiful black swans swimming about in the still water. And jacanas or lotus-birds are building there, while perhaps a splendid eagle-hawk is floating overhead, watching his opportunity to pounce down upon some bird or animal for his breakfast. It is interesting to see him pursuing a flying fox, for he will decide upon one of these creatures and will then cut him out of the flock and fly off to eat him in peace. Some of these birds grow to huge size, and they seem to float in the air for a long time without flapping their powerful wings, or with one or two strokes they will flash out of sight. To see such birds in captivity, with their eyes full of an intense despair, as it seems 


\section{I84 WANDERINGS IN QUEENSLAND BUSH}

to me when I see them, is to gain no idea of what they look like in their wild state, any more than you can judge of the effect of a humming-bird in the forest hanging over a flower from seeing its dead body in a glass case.

A very strange range of mountains in the north, somewhat resembling the Glasshouse Mountains, is the Black Mountain Range. These are so called from their colour, for they are of granite, with all the vegetation washed off by time from their summits; and they are covered with a black lichen, which has also covered many of the loose boulders lying about. One of the strangest peaks in all Queensland is Mount Peter Botte, a mountain built of loose boulders, with a gigantic top made of two vast blocks of granite. There are crevices in this and the neighbouring heights in which cattle are said to be lost sometimes. It is said that when the blacks were pursued in the early days of the colony they disappeared into the mountains and were never seen again. But after a time cattle began to disappear too, and could not be found, and it was thought that they strayed into the mountains and dropped into the crevices upon the torn sides. But one day one of the heights was scaled, with great difficulty, by several enterprising men, and they found upon the summit the marks of many fires, and the bones of many animals; so the disappearance of the blacks and cattle some years before was explained. Sometimes these beautiful wildernesses are the scenes of bush fires, which are lighted by accident, or sometimes by design if it is desired to burn the scrub. Several touching stories of these fires and floods are told which show the devotion of a mother to her young ones. 
One is told of a hen, near one of the stations, whose burnt body was found when the fire had passed, but beneath the poor charred remains five little chicks were found in perfect health. There is no doubt the mother could have escaped, but by so doing her babies would have perished, and she preferred the other alternative. A similar story is told of a mother pigeon in a tree, whose dead body was found after a flood still trying, this time in vain, to shelter her young ones by giving her life for them: in this case too she could easily have saved her own life, but she gave this to stay with her young ones.

Climbing amongst the rocks in Queensland one sees many beautiful flowers, such as the hoya, which I also found on the summit of the Glasshouse peak I climbed. Here it is again, and in company with a glorious orchid of pink and black and another of mauve and white. Lizards are running about too, and a watch must as usual be kept for snakes, for no place in Queensland seems safe from them. And rock-wallabies live here too, in some numbers; these were once much prized by the natives for food, but as these have now for the most part disappeared the wallabies may be expected to survive for many years to come in their rock heights. Farther down in the valleys are the trees where the tree-wallabies live, and hang upon the outmost branches, which sometimes break beneath their weight; but they do not seem to suffer from their falls; at anyrate they prefer to keep to the topmost boughs, from which they have nibbled every leaf, in order to see the country all round them. And considering the way all species of the fur-bearing animals have been slaughtered 


\section{I86 WANDERINGS IN QUEENSLAND BUSH}

during the past few years it is wonderful that so many have survived up to the present, for it has been calculated that in one year alone (I9I9-I920) five and a half millions of the skins of the opossum (which is a phalanger by the way) and one million bear skins passed through the markets of Australia ; therefore it is as well that the Government of Queensland is at last trying to protect them before they are exterminated.

In the deep valleys of the north tree-ferns grow to an immense height, and cycads also, and the cones of the latter are eaten by the cattle when they get the chance. Unfortunately these have a bad effect upon them, and unless they are stopped from eating them paralysis sets in, and this seems to be incurable. Another tree one constantly sees is the handsome bunya-bunya pine, with its cones thirty inches across. Indeed some of the seeds and pods of these Queensland growths are enormous in size. I brought away a pod over a yard in length, and there is a creeper which bears pods of many feet long.

Some of the birds seem strangely tame, where they have not been molested. I remember coming upon an owl one evening and standing quite close to him. He did not appear afraid, only a little surprised, and I could have touched him but feared to alarm him. I remember also walking within a foot of a mopoke one evening, but he did not stir. The butcher-birds are too tame: they will fly into a room where one is sitting and take food from a plate, and indeed in one of the suburbs of Brisbane it was almost impossible to keep canaries, for the butcher-birds continually killed them, the canaries seeming too frightened to 
try to get away. One bird I know of killed four one afternoon at Wynnum.

Sometimes one comes across interesting migrations of animals or birds or insects, though where they are going to or for what purpose is often a puzzle. One migration was of the jerboa-like rats of Australia, which were migrating towards the desert, mile after mile of them, though when they got there they must perish of hunger or thirst. There seemed to be no meaning for the migration, only some blind instinct they were apparently obeying. And on the coast one sometimes sees thousands and thousands of butterflies flying out to sea, only to be drowned as far as one can judge. But the parrots and lorikeets which fly to the north do so for a very good reason, for there are their chief breeding-places, in the dense scrub, where they can live at peace It is about one of these bird migrations that $\mathrm{Mr}$ Quinn has written - that of the black swans, who at a certain season of the year make for the north, flying far overhead and adding one more to the bird-sounds of the Queensland night :

"A stillness broods on hill and tree,

Along the coast there gleams no light,

As over darkened land and sea

Black swans go trailing through the night.

A large star glimmers in the west,

One star unclouded pulsing light ;

I know not what may be their quest,

The purpose of their darkened flight.

Oh, I would know the peace they feel

At dawn upon some water-place

By stirless reeds where never keel

Sows ripples on its gleaming face. 


\section{I88 WANDERINGS IN QUEENSLAND BUSH}

And I like them, at sunset hour, On some green swamp would love to brood; Where tall rush-spear and red brush-flower O'ertopping fern and bracken stood.

They know their pathway through the wide Dark night o'er headland, reef and dune, The falling tide, the flowing tide, On salty creek and lone lagoon.

The night is thrilled with mystery, On land and sea no light shines forth As over rock and dune and tree The swans go trailing to the North."

Just one more bird must be mentioned, for it would not be fair to leave out all mention of such an extraordinary bird as the cassowary (C. Australis), so curiously Australian in type. This shy creature haunts the deep scrub of Northern Queensland, and in some dark dense cover she lays her four dark green eggs. She has sometimes been betrayed by her bright head and neck, and the curious horny crest she bears on her head, just as the ring round the scrub-turkey's neck sometimes " gives her away" when roosting on a tree ; but the cassowary takes no risks and is never seen unless one is prepared to go far into the bush after her. She is one more of the strange survivals of Australia.

And one interesting experience to me was that in the heart of that remote part of the continent, and in the most unlikely places, I was suddenly brought back to England in fancy by finding two English things.

Once I was on the top of a mountain, and on that arid spot I suddenly found, between two stones, a real English sundew, just such an one as I have found hundreds of times in the boggy places in Hampshire 
and Sussex, and in hundreds on the common near Woking. How the plant could survive under such arid conditions I could not imagine, but there it was, with the little ring of dewdrops, as if it were growing in a bog in the old country.

One other creature I found was a bloodvein moth. I was watching some bottle-trees, and thinking they looked like plants stuck in huge bottles, when a little moth flew out of one of them and settled near me, and I saw it was a real English moth. I felt as if I had met an old friend in that great solitude.

Other English acquaintances were not so welcome, as, for instance, the numerous sparrows, whose pert ways were so familiar to me at home and which I found too much at home out here. It is said these birds were imported to check the insects which feed upon the fruit in the orchards, but lost their good name when it was found they ate the fruit themselves. The Government curator at the Zoo at Melbourne tells an interesting story of an iguana which he watched there catching these birds. He lay in wait for them and snapped them up without swallowing them, and the listener distinctly heard several faint chirps even after they had-as he expressed it "reached their destination." 


\section{CHAPTER XV}

\section{POLITICS}

IT is with fear and trembling that I approach the thorny subject of politics - a subject that I do not love in any country ; but they can hardly be avoided in Queensland, for they occupy much of men's minds there at present. As I do not know anything about them out there, except what an outsider could glean, I shall only reproduce two conversations I had with two men who may be considered representative of the opposing points of view ; and as I took down what they said at the time I trust I shall reproduce their views pretty exactly. I will put them in the form of two conversations, and I am not in the least responsible for what either said. The first was one of the squatters of Queensland, and he may be said to be a fair representative of the pastoralists, and is personally a man of the highest character and standing in Queensland. My part of the conversation consisted of questions designed to find out the squatters' point of view on the subject of the recent legislation.

"What do you think of the prospects before Queensland at this moment? "' he was asked.

"I think we should do very well, when the prevailing slump is over, were it not for the men in power at this moment."

"What in your opinion is their mistake?"

"They are anxious to secure their majority and 
to do what they think will please their followers. This renders them grossly unfair to the old settlers, who have had so many difficulties to overcome in the past."

"I understand they think the pastoralists hold too much land per head; is this so?"

"What they refuse to see is that it is necessary to hold an enormous amount of poor land to make a bare living. For instance, in many parts of the poorer districts fifteen acres or more are needed to feed a single sheep, and of course in bad seasons it would require far more than this. Added to which the pastoralist has to reckon with floods and droughts, etc. One wind-storm blew five hundred sheep into the water in one day. Then in seasons of drought, for instance, one loses almost all one's sheep and cattle, and there is no compensation for this. I have sunk bores at enormous expense in some cases, but of what use is a bore producing plenty of water when there is not a green blade to be seen for many miles ? Then after a drought like the last, which has lasted three years and only broke last February (I92I), the rains came with a terrible rush, and in one day eight of my dams burst, from the huge flow of water which flooded miles of country and killed some of the remaining stock."

"Do they make no allowances for all these difficulties?"

"Practically not. One is supposed to be allowed to appeal, but it does not avail much unless the squatter or pastoralist is absolutely broken, when the new laws become a dead letter.'

"Are many of them broken?"

"A good number of my own friends have sold out 
and left the country; no country on earth can get on without capital, which is now leaving Queensland when it can be moved. I myself have sold many thousands of acres by degrees, but no allowance whatever is made for improvements made on the land by my people before me and myself. You see, we are amongst the original landowners, so I hold my land upon a different tenure to the new men."

"What is the new method?"

"The Government will no longer sell land, but grant it in what they call 'perpetual leases'though nothing on earth is 'perpetual' with them; for they have shown that they do not hold to any lease or contract when they desire to break it."

"Is this literally true?"

"Absolutely. For instance, in the original leases the leaseholders were promised that under no circumstances would they be reassessed higher than 50 per cent. at any single time; the reassessment, I must tell you, being made about every seven years ; now, in many cases I know personally they have raised the rent by 300 per cent., or even 400 per cent., at the last assessment, and though the leaseholders appealed, nominally, I do not know amongst my own friends of a single case where the appeal has been allowed, except when they were absolutely ruined. Under these circumstances what security can anyone feel ? Added to which I must tell you that the new law has been made retrospective."

"Who are the main- I mean, who are the chief capitalists in this country?"

"Most of the big enterprises are financed by English companies, who found the capital. These companies now find their dividends gone to nothing, 



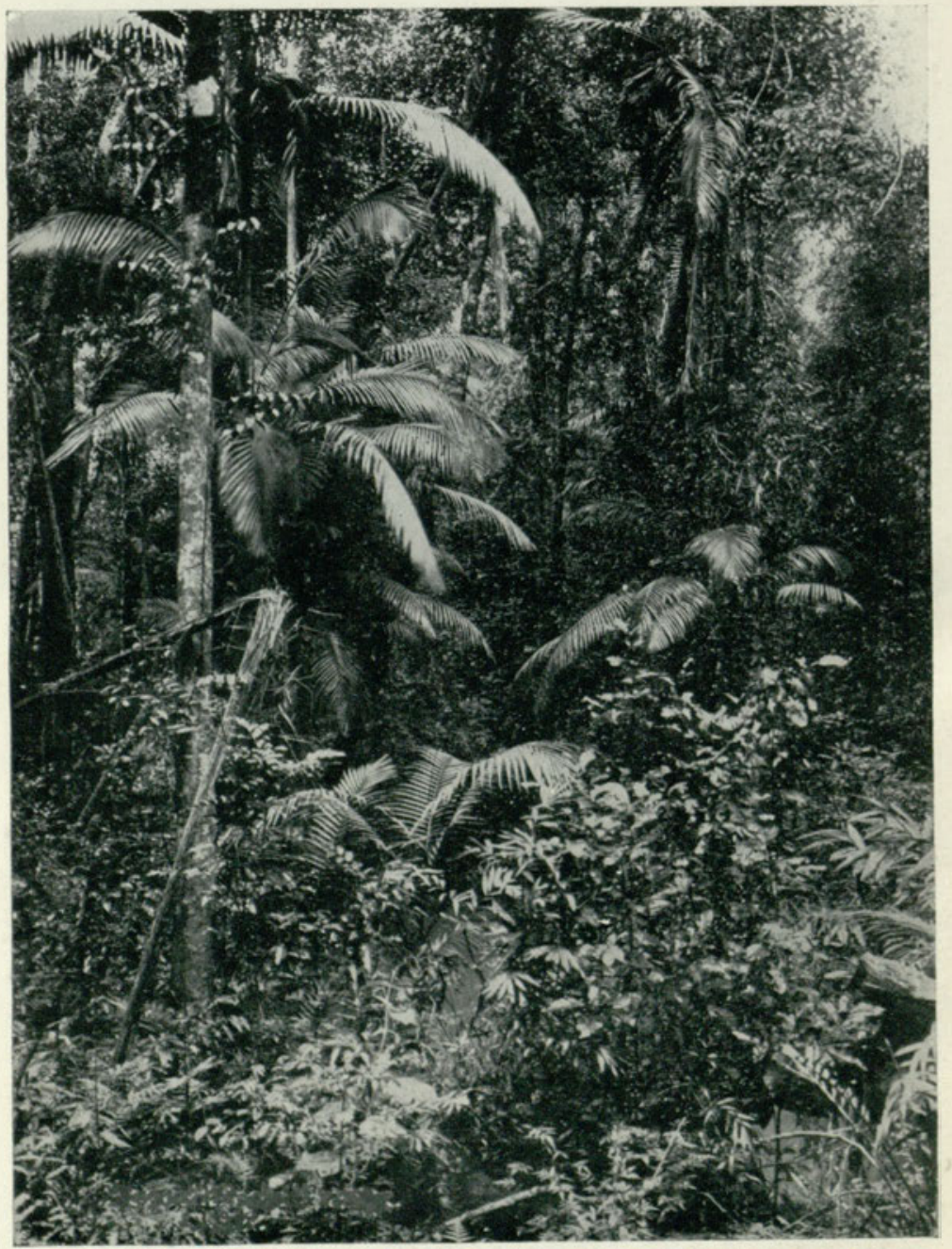

Board of Agriculture, Brisbane]

SCRUB SCENERY 
and they will not longer lend money on empty promises. The Government have found out to their cost that they cannot raise the money anywherefor their credit is gone-and they are talking of raising a forced loan. You know what this means."

"Are they more successful in their other legislation?"

They have been unsuccessful in every venture they have undertaken. They boast that they have made their butcher shops pay, but this is only done by compelling the sheep and cattle owners to sell to them at a very low figure or pressure would be brought to bear upon them. This has driven the price of stock to an extremely low level. I was offered $£^{2}$, Ios. per head the other day for a herd of cows, and at last sold them for $£ 4$. After the recent drought, when cattle and sheep are so reduced in numbers, the price should have been upwards, not downwards; but there are too many difficulties in the way of the cattle and sheep farmer at present, and they should be helped, not hindered, by the laws of the country.

"Then look at the roads and railways. You have yourself commented freely upon our roads; in fact, as you say, except near the large towns we have none. As regards the railways too, the trains are getting fewer and fewer : at this moment we have not even one a day to our nearest station, which is many miles away, and this is one of the main lines across Queensland. This is on the plea that railways do not pay; and indeed the Queensland railways do not: they are heavily in debt, the rolling-stock is wearing out and when it is gone we are wondering what will happen. 


\section{I94 WANDERINGS IN QUEENSLAND BUSH}

"Then, too, their system is so bad. The other day my wife and daughter objected to the fact that the pig-truck was fastened directly in front of the first-class coach, and that on a very hot day. When this was brought to the notice of a high-class official the only redress they got was the reply: 'We cater for the whole community, and do not undertake to study the fastidiousness of the few.' This sounds very well, but then why have two classes on the railway at all? Surely you need not pay extra to travel with the pigs close to you?

"And it is the same with the Post Office and the fish shops, and everything else. The so-called rulers seem to me to spend their time-and the ratepayers' money-running about the whole of Australia in cars or launches, and are seldom at their posts. This is freely commented upon in one of the papers, which gives every week an account of where each member is at the moment. They claim it is on public business, but even their own followers do not believe this-in most cases, at least, though there are honest men amongst them, but even they have not learned the art of governing, and are full of theories."

"Do you believe they will remain in power?"

"I am sure they will not. Their own followers are breaking away in some cases. They know well enough they will go out of power at the next General Election, and I verily believe it will be a great relief to them when it comes, for they will hardly be able to carry on for the next year or two.

"I think their whole system is wrong. They boast that a few men are paying almost all the taxes and they desire to eliminate the capitalist class. They enter into most unfair competition with private 
enterprise and so break small and big men. I would very much like to help any small man setting up, and you see for yourself what we have done here in the way of co-operation. Our creamery sends round a van every day through the bush and picks up the can, or perhaps two cans, each small owner places at convenient spots in the bush. Our one industry all round here is stock, as you see, so this helps the beginner, and in this way he can gradually get on. This is far better surely than State interference?

"I believe they know well enough they are on the wrong tack, but they do not see how to go back to the right one. No one is satisfied with their guidance of State affairs, and you will see at the next General Election what the country thinks of them. There was a debate recently on a 'Want of Confidence' vote in the House, and they only just scraped through. But in any case I believe their days are numbered as a government.'

"Do you believe in the future of the country?" "I do-in the future; but I do not know when that day will come. The country is rich enough, but cannot at present develop its resources. There is a slump all the world over, as you know, and no one feels settled or comfortable. We want settled conditions all over before any country can really go ahead. But personally I love the country and have spent all my life here, and sincerely hope she will come safely out of all her troubles."

My second conversation was with a member of the Queensland legislature, a most kindly, intelligent man. He answered every question I put to him with the greatest frankness, and I am sure that 


\section{I96 WANDERINGS IN QUEENSLAND BUSH}

he was a most favourable specimen of the ruling class.

"Do you mind my asking you quite freely what you think of the new land laws and if you consider them just to the pastoralists? " was my first question.

"They are not really new at all, but a revival of the oldest laws. The oldest leases were framed with a view to changes if necessary, and a clause distinctly stated that they were subject to revision. It is true this clause was left out of more recent leases, but we have reinserted it. Surely this is just enough?"'

"But the pastoralists took their land upon a certain understanding. Do you think it justifiable to alter this understanding ?

"Certainly, if the good of the country demands it. What country in the world would allow itself to be strangled by the 'Dead Hand'? In this case we found that a few men were holding huge territories-as large as an English county in some cases-and the closer settlement of the country demanded some of this land for a number instead of a few. Do you not think we were justified in sacrificing a few to the many?"

"This is the 'Scrap of Paper ' theory, is it not?"

"In some measure-yes. . But when a body of men are placed in authority they must be guided by the interests of those they are supposed to be looking after, not by the interests of a few, who have already reaped so much benefit in the past for themselves."

"But how far would you go ? You see, if you allow this principle, what security has anyone for the future?"

"The certainty that we shall do nothing we can 


\section{POLITICS}

avoid to create difficulties. As it is, anyone who considers himself aggrieved can appeal in each district. You see, we ourselves are in great difficulties. The Governments of each state of Australia are hampered by debts due to the war. Before that disaster we were more than making our way; but now we absolutely must balance our ledger; otherwise bankruptcy will be the outcome, and that could benefit no one."

"Yet you have great resources?"

"Enormous resources, as you say; but at present we cannot realise them. You remember the story of Pat and the Englishman who remarked to Pat, who was selling his pig for a song in his local market: 'If you took that pig to England, Pat, you would get more pounds for it than you are now getting shillings.' To which Pat replied: 'Yes, your Honour, and if I took the Lakes of Killarney to Hell I should get maybe a thousand pounds a drop.' We are in that position to-day.'

"Then what do you chiefly require now ?"

"Before everything else we want population and capital-but not capital in the hands of a few. We shall get the capital all right in time, but just at present there is great difficulty about it, for we are - most unjustly, as I consider-under a cloud. You see we took office at a most difficult moment, at the end of the late war, when the finances of the country were in a hopeless condition, and we were left to straighten out the tangle made by others. It is unfair to blame us for the result.'

"I find though that many emigrants complain they are not met with open arms ?"

"Because they are the wrong kind. We do not 


\section{I98 WANDERINGS IN QUEENSLAND BUSH}

need any more people crowding into the towns and taking away what work there is there from our own people: we have too many town-dwellers already. We want men who will work on the land and go 'out-bush,' and women who are prepared to do the same ; no others at all at present."

"What crops are paying at present ?"

"At this moment, very few, for there is such a slump all over the world; but this state of things cannot last. We are exporting wheat to Europe, and they will take all we can send, and that only of all our crops pays splendidly. But of course a great deal of our land is not suitable for wheat. Then, too, if you ask about just the moment's conditions, we can get very good prices for our fruit owing to the late drought in England, which damaged their berry fruit I understand. Therefore they seem to be short of fruit for jam and future use, and they are buying ours; and, as you see, our land is very well adapted for fruit-growing; indeed in some parts, such as New England, we have only just begun to show what we can do."

"I am staying on a pine-apple settlement. Do you think there is any fear of overdoing such a crop, for instance?"

"Yes, for the present, unless pines become a staple article of food instead of a luxury. We shall have to find a market overseas, and in order to do this we must come into competition with the crop from America and other countries; but happily our pines are making their way and, partly owing to the recent drought, as I say, we have sold out our last crop and are now ready to market the next.

"Then, too, as time goes on we must make up our 
own products. It seems ridiculous that our wool has to be sent across the world to be made up, and our cotton, and every other native produce almost-except sugar. All these will gradually no doubt come to be made in Australia, for we have all the means of production out here."

"This will hit England, will it not ?"

"I am afraid it may, but all the Empire must draw closer together and make a family concern of it, so that the benefit of each part will benefit the whole. It cannot benefit England that we should remain in difficulties when she is our chief creditor."

"It appears not. But may I ask you, can nothing be made of your timber? In the settlement where I am staying at present they are ring-barking every species of timber, some of them of great beauty and value. Yet it is within a hundred miles of Brisbane, and within three miles of a railway. And meanwhile I see you are speaking of planting trees in many parts to save timber."

"Certainly this subject wants attention. I did not know what wholesale destruction was going on, but at present the ground must be cleared for planting. You see, our forests all grow in one half of the country, just where land is fertile and required for cultivation. Still, any timber which is valuable for any purpose should be saved if possible, and at this moment there are several schemes on foot to try to make use of our various resources-such as paper-pulp, amongst other things."

"You are determined-as a Government-not to sell any more land ?"

"We believe in State control of land, and are willing to lease it on perpetual leases, but not to sell 


\section{WANDERINGS IN QUEENSLAND BUSH}

it. Such leases are as good as freehold as long as the holder is prepared to pay the rent, and we find that in almost all cases the holder is content with this arrangement. At all events, we do not want to get into any further difficulties by the whole land getting into the hands of a few, which has led to such difficulties in the past in many countries, not only our own."

"Do you think the future of Queensland is assured ?"

"I am absolutely certain of it. Our difficulties, of which one hears so much, are only temporary. We have had to face them with the other states out here as well as with outsiders; but nothing on earth can keep us from rising in the end. There are boundless resources in this state, and we have every element of wealth when once we can realise our assets. What do we lack in the way of assets? We have rich soil in many places ; gems of almost every kind, including a few diamonds, and there must be more where these were found; we have plenty of coal and iron, gold and silver, and, in fact, all that is required for future wealth when we have got the required population and the initial capital to work our mines and land. Then, too, gradually we shall make our own goods, and the circulation of money will bring wealth. And, finally, when once they have found out the beauty of our country, tourists will come here from other countries. Do you not think so ? And indeed I should like to know the opinion of a stranger."

"I am delighted with your country, and I agree with you that if the tourists of Europe only knew what awaits them here they would flock to your beauty resorts. Indeed I am glad that I saw your 
beautiful land before the rush came, for I consider you have a gold mine in your lovely scenery, your perfect winter climate and your splendid vegetation. And personally I shall never cease to be glad I have seen Queensland as it is, and not what it will one day be when it has been-'Discovered.'

There were several other topics I should have loved to touch, but I did not dare strain further on the courtesy of the speaker, who held a high position in the legislature and whom I knew to be a very busy man. Otherwise I feel sure he would have answered with the same freedom and candour as he had done throughout the conversation.

Much as I hate politics I have thought it absolutely necessary to give this brief outline of the different views held to-day in Queensland on several points of policy-views which may diverge without proving that either side has anything but the good of the community at heart, though their opinions may differ as to the best means of securing that end. But upon one point all are agreed-as far as I could ascertain-that some day the state will rise to success. And personally I feel sure of the same thing-how can it be otherwise in the end? So all who know the country will say with Mr Kipling :

"Suffer a little and my land will rise

Queen over lands indeed."

After all, party politics, however keen, get out of date: people, and even parties, change their views; but happily the resources of a country last beyond the moment's debates, however heated ; and if only all are sincere in their aims Queensland must at the end "win through." 


\section{CHAPTER XVI \\ "THESE FROM THE LAND"}

AT last my days in Queensland were numbered, and already in Burton's phrase I could hear " the tinkling of the Camel's bell." It was with great regret that I turned to leave, for I may honestly say thatoutside my own country-I have never loved any country I have seen as I do Queensland. I think it is partly the sense of freedom there, as well as the kindly nature of the inhabitants and their lovely country, which all combine to make it a land of charms-as well as a land of "plenty of time." Personally I went there as a stranger, knowing scarcely a person in the state, and left leaving a host of friends. But before closing there are several things about which I do not think I have said enough.

First as regards the mountain ranges there. Though these are not high, there is a wonderful variety about them; they are mostly high tablelands, so that mountaineering in Queensland is rather reversed. You start out in the morning to go downwards and descend torn, scarred ravines, and ascend in the evening to the heights you left at dawn. But what ravines they are! As you go deeper and deeper down some wonderful gorge you pass glorious waterfalls, tumbling from height to height, sometimes catching the light and then rainbows-sometimes several-are seen in the clouds of spray. Many of these have not even a name, as yet, 
and even the streams are nameless too. Sometimes you come upon a river which comes out of the ground with a roar from some unknown water-course and flows down its rocky ravine until it suddenly disappears again into the earth whence it came; sometimes it flows downwards hundreds of feet, with huge tree-ferns and cycads fringing it and always wet with the spray, until at last you are down past the region of vegetation, and far overhead you see a thin strip of sky. If a storm breaks while you are down below you hear the thunder rumbling amongst those deep ravines with terrific force, or if the sky is clear you may hear no sound more formidable than the crack of the stockwhip-bird calling to his mate or in rivalry with others of his kind. And you may have to cross the stream which has torn away this deep gully a dozen or more times when you are struggling upward to the light above. Then as you ascend you come to the region of trees, and how such mighty giants as some of these maintain themselves on those rocky ledges is a marvel.

But some ranges are not like these: there are heights which come near the coast-line, such as the Bartle Frere Range and the Bellenden Ker, near Babinda and Innisfail in the north, and the Black Mountains and Glasshouse Peaks, and the extraordinary Pinnacle Rock on the plains, made of rotten conglomerate; all of which must have been raised in some convulsion of nature such as made the terraces of inverted sandstone near Springsure, which resemble those of New Zealand-though the latter are of sinter. The rocks all over Queensland are of endless amazing shapes. Thus Mount Peter Botte is a huge knob of granite, while Coonagrin is a pointed 


\section{WANDERINGS IN QUEENSLAND BUSH}

cone. Some heights are like pyramids at the top, others are flat-topped and others are like sharp wedges set on end. Many look as if they had been carved by giants-so strange are the shapes they assume; while many districts are almost composed of curious stones and boulders. For instance the country round Stanthorpe is full of boulders of all sorts and shapes. There are the Sentimental Rocks, like some huge amphitheatre, and the gigantic boulders without names on Mount Hardy. There are the Two Brothers Rocks, two huge boulders exactly alike in shape and size. This, by the way, is the country of the bushrangers, who liked being on the borders of a state so as to escape over the frontier if necessary. I must tell of the last exploit of "Captain Moonlite" and his gang, who were almost the last of the bushrangers, and almost the most famous of all. This man had earned a terrible name for himself and his gang, until the whole country round was almost at his mercy. The end came suddenly in the following way.

Captain Moonlite appeared suddenly at a border station called Wanterbadgery, which was in the possession of a young man named MacDonald, who had lately come out from England and had not long before left Harrow. He was not wanting in pluck, but the number of the gang overcame all possible resistance and the Captain-who was evidently a man of education-compelled MacDonald to have supper with him. While they ate they talked, and the Captain asked MacDonald if there was anything he had taken which the owner particularly prized. MacDonald replied that the thing he most regretted losing was a presentation cigar-case, whereupon the Captain with a bow restored it. Next morning they 
left the station-though they left a guard therein order to "hold up" the bank in the local township near, which they accomplished, returning in the evening to the station. That evening the Captain shot the owner's horse in a fit of temper. When MacDonald asked the reason Moonlite said he deeply regretted doing so, but added that his infernal temper had always been his chief drawback and had got him into endless scrapes. He had, indeed, shot a man only the day before in a fit of temper, and this was by no means a rare occurrence. Just as they were speaking, one of the gang entered the room and told the Captain that a stranger was seen approaching the station on a horse. To which the Captain answered, without turning his head: "Hold him up and if he refuses shoot him dead," and went on eating. The horseman, however, seemed to have changed his mind, and rode off without seeing anything unusual.

But he had noticed something wrong, and went off for the police in the neighbouring township, who were on the alert, owing to the bank robbery, and before morning the station was surrounded, and in spite of every resistance, and the shooting of several of the police, the gang was captured or shot, and the Captain himself was taken alive. He was conveyed to prison at Sydney and underwent his trial. While there and awaiting sentence he sent for MacDonald, and asked if there was a chance of his life being spared, to which MacDonald replied that there was not. "That's all right then," said the Captain, and asked for a cigar.

It appeared that he was the son of a clergyman, named Scott, and had been sent to school, living with an old aunt for the holidays as the school was far from his home. Here, after receiving great kindness 


\section{WANDERINGS IN QUEENSLAND BUSH}

from her, he stole her money one day and ran away to sea, and after many wanderings made his way to Australia. Here his daring and lawlessness got him into trouble with the authorities, and at last he became an outlaw and took to the roads. He was a most remarkable man, and exerted a strange fascination over all with whom he came in contact, which is all the stranger since he had a villainous face, with large, protruding eyes, and a wild shaggy beard. His cave in the Mount Hardy Range is still shown.

I think the most extraordinary effects in Queensland are caused by the mists and tones amongst the mountains. The Blue Mountains receive their name from their intense blueness, and though less well known the Queensland ranges deserve the same title ; no one who has not seen these chains could believe the depth of colour which spreads over everything. I remember standing on a summit of one of the chains of the Main Ranges one day, with endless peaks and hills all round me. Some were rounded like our downs; some were very evidently filled-up craters of long extinct volcanoes; others were "Plugs" of basalt here and there. I could not help recalling the lines of a Queensland poet, and thinking that they applied to the whole country and not to only one part of it, to which he had addressed the words:

"Dark purple chased with sudden gloom and glory,

Like waves in wild unrest,

Low-wooded billows and steep summits hoary,

Ridge, slope and mountain crest.

There have been dreams for thee by those who slumber

Sound where no voice may reach;

Who ere they joined the host that none may number

Saw what they strove to teach." 
"Dark purple"-that is the exact tint of the distant ranges, but the nearer ones are intense blue, and the foreground only appears green.

And the lights and shadows of the morning and evening are past description-the foreglow in the morning over the plains and the unearthly beauty of the sunset behind the guns. The weird scenery, and the endless sounds and sights and scents, and the curious animals hopping about, and the "strange bright birds" flying in flocks overhead, and a number of other wonderful things, make the Australian bush a thing to dream of.

I think if I were asked what struck me most about the Queenslanders, after their kindness and hospitality, I should say their love of horses. Many of these are beautiful animals, capable of holding their own anywhere, for racing is a passion with all Australians. No one seems to walk a step if he can ride, and it is a common saying that " an Australian will walk two miles to catch a horse to carry him one mile." The men ride everywhere; they ride to church-if there is one; they ride about the streets lighting the lamps; they bring your letters on horseback; they go to get stores in the nearest township on a horse and return looking like walking stores. And the women back them up, for what a woman in the bush cannot do with a horse no woman on earth could. And the horses are often of splendid physique, for they are asked to do a great variety of work-like their masters-and seem able to endure a great deal. I remember seeing a strange sight one day. I was driving along a terrible track with two others, and we came to a deep stream across the road, with a steep side on one side and a gully on the 


\section{WANDERINGS IN QUEENSLAND BUSH}

other. I preferred to get out and cross the stream by crawling along a log which had fallen across it, and was watching my companions trying to cross, when I saw that the cart had stuck, so they put the horse at the side in order to turn. The gallant animal then tried to climb the mountain-side, with the heavy cart behind him, and was literally sitting up while trying to do so, as his hindquarters were touching the ground. However, he was eventually turned, though the tail of the cart was also on the ground and the occupants had to scramble out in the water for fear of being thrown out. However, no Queensland horse seems surprised at anything-or at being asked to do anything.

Another curious sight in Queensland is that of the men who "hump their bluey" from station to station offering to work. They carry their whole worldly goods with them on their backs, and are often accompanied by a thin dog. These are often men who do not care for a settled life and prefer to wander, but they often work well enough for a short time until they get tired of a place and wander off. A story is told, so ancient that it is not allowed to be told in Australia, of two such men who wandered in company without exchanging a word most days. One evening the silence was broken. "There's a dead horse," said one. "That's not a horse, it's a cow," said the other. Presently they lay down to sleep for the night, but next morning Bill had gone, leaving a note on which he had written: "Too much argufying in this 'ere camp."

Many of these "Wallaby" men make a good living, for they can usually turn their hand to anything, whether shearing or stock-driving or clearing 



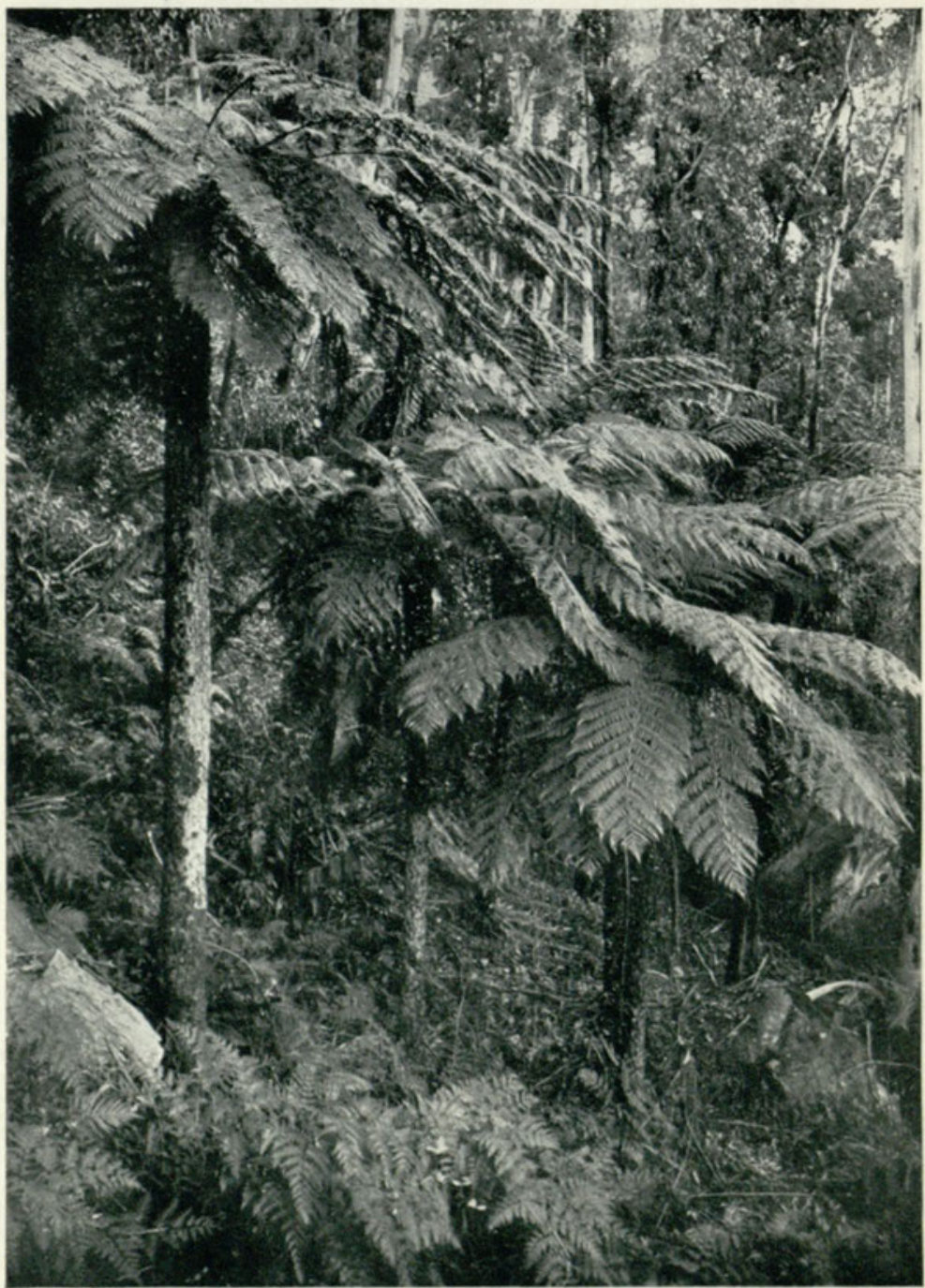

TREE-FERNS 
the ground, or whatever is required of them. I several times saw a handy little implement for tearing the tough roots out of the ground being worked by two of these men. It is called a "Forest Devil," and is fastened to a tree, while a chain or cable is run round the root or tree to be taken out. One man walks backwards and forwards, giving a turn to a wheel which works a $\operatorname{cog}$ every time it is turned. Gradually the force is increased as the chain grows tighter, and at last even large trees are torn out by the "Devil."

Sometimes one comes across a selection which has gone back to bush, and it is surprising how soon the bush will cover up the traces of man, though the trees may not be tall yet. The once cleared land is covered with sprouting gums, with their brilliant young red leaves, and huge weeds are growing too. Perhaps the dreaded pear will be there, struggling to overcome all resistance, or the lovely N'Gurra Bur, with its silver leaves and gold flowers, and faint traces of past crops will be struggling to show themselves and to show what once grew there: a few plants of maize, or " mealies," a sickly papaw or two, or a dying banana which has taken all the good out of the ground it has ruined. Or the brilliant flowers of an arrowroot plant will be seen, or a passion-fruit still trailing on the piles. But all the rest is desolation-for a ruined or deserted homestead is far more desolate than the wildest natural scene, even as an empty nest is a melancholy object in a winter hedge at home.

One such homestead struck me particularly. It had belonged to a man who had lived and died alone. 


\section{IO WANDERINGS IN QUEENSLAND BUSH}

He had cleared the ground, but the work had proved too hard for him, and he died rather suddenly. His neighbours spoke of him as a quiet, industrious man, but he had come as a stranger amongst them and had had few opportunities of making friends with them. Therefore, though they spoke kindly of him, none had known him for long; and as there was no graveyard near he had been buried there where he had hoped to have made a living, and where he was trying so hard to dig himself in. It was a lonely ending, and his grave is now overgrown and forgotten, except when a casual question is asked about it. There are many such endings " out-bush," but I do not know that one could not rest better so than in a crowded cemetery at home.

\footnotetext{
" A bare mound without wreath or stone

Marks where he sleeps 'mid grasses long,

Who sought not things that others seek;

Who fought in silence and alone;

Who in his weakness was so strong

And in his strength so weak."
}

And I am not sure that he could have chosen a better place to rest than the spot where he was laid; for the bush voices would be above and about him, and the parrots would scream in flocks as they settled on the white flowers of the ti-trees, and the gentle opossums might climb the trees above his restingplace, and the flying foxes leap at night from the branches, and the honey-birds would suck the flowers of the orchids, and the mopoke call, and the bell-bird, and a thousand others. So if he loved the wild things he would have chosen just this spot, I should say, where he and they were at peace. Of course had he lived he might have resented their presence 
-they might have damaged his crops or killed his stock. But it did not matter now; nothing mattered, not even the dingo, who could rear her family of little red pups in the hollow log near where he was lying.

Personally, in looking back, I can see that all the happiest days of my life have been those passed in utter solitude-solitude, that is to say, as far as human society was concerned; for the lover of Nature is never solitary if he is left alone with her in congenial surroundings-that is to say, where she is left free and unrestrained and with plenty of her wild children for company. And I think this is the true secret of the seduction of Queensland, for it is so easy to get off the beaten track here where there are so few beaten tracks ; and everyone lives more or less the life heor she-chooses, unhampered by the consideration of what others will think; and besides, even where settlers have established themselves, they do not interfere much with wild nature, except just round the houses. So even the stock roam about in gigantic paddocks, mile after mile of trees all round them, looking as they would do in England if they had escaped into a wood ; and semi-wild horses only fit into the landscape without changing its character ; and unless the kangaroos become so numerous that they eat the settler's grass, and have to be "driven " to their death, they are not much hunted now, so that they can sometimes be seen hopping not far from where the cattle or horses are grazing; and in the denser scrub, in all the scrub-lands, very little has as yet been done to destroy the beauty of the whole scene. Some day this will change, but that day has not come. It may come with the "million farmers" 


\section{WANDERINGS IN QUEENSLAND BUSH}

who are to be brought into Australia in time, but I am glad I got there before they did. It may possess other advantages, such as civilised man brings with him, but not the advantages I care for ; so I am glad I came in time.

I shall never forget the evening when we drifted down the Brisbane river in the glory of an Australian sunset, almost the last I was to see. The sky was of brilliant red and green-that vivid green one never sees in colder latitudes, at least, not of such an intensely bright colour; there were long streaks of both in the sky that evening, and we drifted, as Evans says of that very river :

"Past meadowy marshland and gray limestone bluff, Low mangrove fens and waste lantana heights;

Long reaches where the winds and tides are roughAnd sheltered bights.

Now wider spread the waters to the eyes;

Now sparser grow the homesteads scarcely seen;

Save where some roof or gaunt gray trunk may rise

Against the green.

And salter on the cheek the breezes blow;

And in a deeper key the river sings;

And from the viewless sea move to and fro

Swift snow-like wings.

These are the voyagers from travelled seas;

Who knows what seas of thought man yet may sail, As Science slowly sifts Life's mysteries

And lifts the veil ?"

And so we passed beyond that " amphitheatre of purple hills," and on past the mangrove swamps, out into the open sea, which was tinged with red from the 
sky above until it looked indeed like " a sea of glass mingled with fire," and steered for Home, with the unearthly radiance of the Australian sunset round us as we went forward with our faces towards the glow. 
Printed in Great Britain gy the Riverside Press Limited Edinguroh 


\section{Selections from \\ George Allen छु० Unwin's List}

Matahari : Impressions of the Siamese-Malayan Jungle

By H. O. MORGENTALER

La. Cr. $8 v o$.

Illustrated.

About 7 s. 6 d.

This Jungle Book of a Swiss mountaineer and geologist is not an ordinary book of travels through wild and unknown countries, but is interesting because its author is a man of humour for whom the lust of wandering and the joy in the beauty of the world are the foundation of all philosophy.

The personal note, the way in which Morgentaler looks at Eastern things, the manner in which he makes the reader acquainted with the strange features of Further India, all give charm to the book and gives the reader pictures of Siamese and Malay life such as few white men can give.

\section{Up Against It in Nigeria By LANGA-LANGA}

Demy 8vo. Second Impression. 24 Pages of Illustrations. $18 \mathrm{~s}$.

"Full of the humour that keeps life sweet. There is a gaiety in the book which is curiously infectious. A most cheerful and companionable volume."-Pall Mall Gazette.

\section{Adventures in Swaziland}

\section{By OWEN ROWE O'NEIL}

Medium 8vo.

Profusely Illustrated.

$16 s$.

"A remarkable book. The picture it creates will last. Dr O'Neil writes of Swaziland with the ardour of a lover, with the curiosity of an explorer, with the sheer delight of one whom boredom has not touched."

\section{The Long White Cloud Ao-Tea-Roa}

By the Hon. WILLIAM PEMBER REEVES Demy 8vo. New and Revised Edition. Illustrated, 12s.6d. "Out and away the best book on New Zealand."-Daily Chronicle, 


\section{Egypt--Old and New}

By PERCY F. MARTIN, F.R.G.S.

Author of The Sudan in Evolution

Fcap 8vo. With 45 Coloured and many other Illustrations. 2 Is.

This is a popular description of perhaps the most fascinating country of all the ages, and is illustrated with beautiful coloured plates and engravings. The writer of the text is an experienced traveller in many lands.

\section{Egyptian Art By JEAN CAPART}

(Keeper of the Royal Museum Cinquantenaire, Brussels)

Translated by WARREN R. Dawson

Royal $8 v 0$.

Profusely Illustrated.

i6s.

This book is a translation of a part of Professor Capart's monumental work Lefons sur L'Art Egyptien, published at Liège in 1920. To those interested in the ancient arts of Egypt M. Capart's name is sufficient indication of the interest and importance of this book.

\section{Master Dietz : His Autobiography}

\section{Translated by BERNARD MIALL}

La. Cr. $8 v o$.

Illustrated.

7s. $6 d$.

Master Dietz, the MS. of which was lately discovered on, the shelves of the Royal Library, Berlin, can only be compared for its frank simplicity and its amazing adventures with the immortal work of Benvenuto Cellini. Johann Dietz was a barber's surgeon who flourished in the latter part of the seventeenth century and lived to see the accession of Frederick the Great. Not only did Master Dietz go through many a hard-fought campaign, he was for some time surgeon aboard a whaler, and his description of Arctic adventures in the seventeenth century is no less absorbing than his tales of war, while we owe to his candid simplicity one of the most remarkable pictures of middle-class life on the Continent during one of the most turbulent periods of history.

The volume is illustrated by miniature reproductions of many steel and copper-plate engravings illustrating battles, sieges, cities and fortifications.

\section{Twenty Years in Roumania}

\section{By MAUD PARKINSON}

Demy $8 v 0$. Ios. $6 d$.

"Miss Parkinson is a shrewd observer of wide sympathies, with a capacity for wide appreciation, and withal a sly humour."-Church Family Newspaper. 




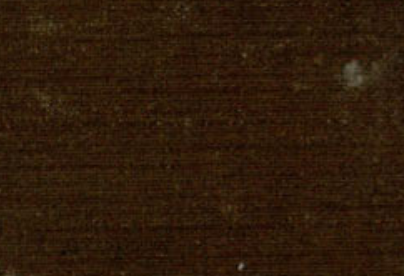

at
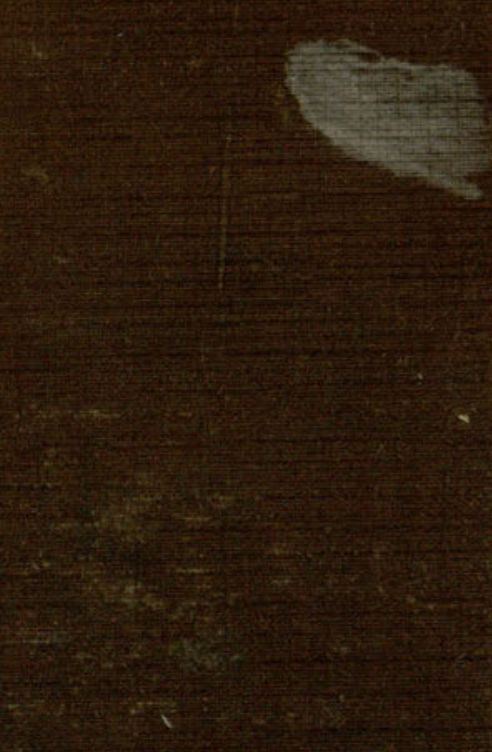

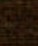

